\title{
Metapolitics and Corporate Law Reform
}

\author{
Roberta Romano*
}

Until recently, corporate law has been an uninspiring field for research even to some of its most astute students. ${ }^{1}$ A survey of the literature suggests that the last major work of original scholarship was Adolf Berle and Gardiner Means' The Modern Corporation and Private Property. ${ }^{2}$ For a defining characteristic of original scholarship is its ability to rechannel public discourse, and after half a century, discussion of the corporate form still invariably begins with Berle and Means' location of the separation of ownership and control as the master problem for research. Their observation is central, for example, to numerous recent reform proposals that seek to mitigate corporate irresponsibility, which is identified as the insensitivity of business organizations to some set of values thought to be incompatible with the maximization of firm profits. ${ }^{3}$ Typically, the Berle and Means separation thesis is invoked to justify the need for new and more extensive controls on corporate actors to restrain managerial wants left unchecked by shareholders or market forces. But there is irony in this use of the separation thesis because Adolf Berle viewed the emer-

* Assistant Professor of Law, Stanford Law School. I would like to thank Lucian Bebchuk, Paul Brest, Robert Clark, Robert Ellickson, Michael Fitts, Ronald Gilson, Robert Gordon, Robert Katzmann, Lewis Kornhauser, Saul Levmore, Henry Manne, A. Mitchell Polinsky, Matthew Spitzer, James Strnad, Oliver Williamson, and the participants in a seminar at Boalt Hall School of Law, University of California, Berkeley for their comments. This research was supported by the Stanford Legal Research Fund, made possible by a bequest from the Estate of Ira S. Lillick and by gifts from Roderick E. and Carla A. Hills and other friends of Stanford Law School.

1. The sense of listlessness is gracefully conveyed in Bayless Manning's fin-de-siècle footnote: "[C]orporation law, as a field of intellectual effort, is dead in the United States. . . . We have nothing left but our great empty corporation statutes-towering skyscrapers of rusted girders, internally welded together and containing nothing but wind." Manning, The Shareholder's Appraisal Remedy: An Essay for Frank Coker, 72 YALE L.J. 223, 245 n.37 (1962). (1932).

2. A. Berle \& G. Means, The Modern Corporation and Private Property

3. See, e.g., R. Nader, M. Green \& J. Seligman, Taming the Giant Corporation (1976) [hereinafter cited as R. NADER]; C. STONE, WHERE THE LAW ENDS (1975); Coffee, "No Soul To Damn: No Body to Kick": An Unscandalized Inquiry Into the Problem of Corporate Punishment, $79 \mathrm{MICH}$. L. REV. 386 (1981). As of a short time ago, there was only a lone voice among legal academics questioning the normative implications of Berle and Means' findings. See Manne, Mergers and the Market for Corporate Control, 73 J. PoL. EcoN. 110 (1965). 
gence of independent corporate managers as a development to be celebrated-a mechanism for producing truly public-regarding servants. ${ }^{4}$

An essential difference between Berle and contemporary corporate law reformers is that he had a normative theory of the corporation and its place in the polity, whereas many advocates of reform are uninterested or unwilling to articulate the vision of the good society that informs their policy package. This observation concerning the new corporate reformers has been emphasized by David Engel, who further ascribed disparities among reform proposals to the proponents' divergent, albeit unspecified, political beliefs. ${ }^{5}$ Engel attacked the obsessive preoccupation of corporate law scholarship with the means of reform, by maintaining that means cannot be cogently evaluated without some prior specification of ends. What I find important in Engel's analysis is not the implicit claim for the superiority of a particular end, but rather, the recognition of the need to clarify and evaluate more precisely the means/end relationship. A requirement of consistency between means and ends is a threshold criterion that meets such demands, as it accords with notions of rationality. ${ }^{6}$ It also pinpoints the important link between corporate law and political theory, that political ideals constrain or influence the form of business organizations. Therefore, in the spirit of the maxim that we should attempt to understand before we judge, this article seeks to move discussion beyond Engel's observation that the vision of many reformers is at best inchoate, by elaborating normative bases for reform proposals. My aim is to construct a typology of democratic ideals that is of sufficient generality to be helpful in assessing the major policy recommendations of participants in recent debates over corporate law reform. The association of specific reforms with political ideals should enable us to gauge more accurately the full meaning and continuing intellectual vitality of the Berle and Means legacy and the direction of corporate law scholarship.

The first part of this article is, then, a response to Engel's chal-

4. A. BERLE \& G. MEANS, supra note 2; see notes 38-45 infra and accompanying text.

5. Engel, An Approach to Corporate Social Responsibility, 32 STAN. L. Rev. 1 (1979).

6. Kenneth Arrow put it cogently:

A truly rational discussion of collective action in general or in specific contexts is necessarily complex, and what is even worse, it is necessarily incomplete and unresolved. Rationality, after all, has to do with means and ends and their relation. It does not specify what the ends are. It only tries to make us aware of the congruence or dissonance between the two.

K. ARROW, THE LIMITS OF ORganization 17 (1974). 
lenge to locate a connection between political beliefs and particular proposals of corporate law reform. It develops a framework for evaluating reforms by identifying core characteristics of differing conceptions of democratic organization. Accordingly, four ideal types of societal ordering are introduced, each of which supports its own homologous corporate structure. In the remaining sections, the article relates recent reform proposals to the typology, starting with internal reform of corporations. The topics of discussion include suggestions for restructuring the board of directors, the information and communication channels within the corporation, and the board's role in a takeover. Thereafter, several external regulatory regimes are reviewed. The distinction between internal and external regulation is admittedly ad hoc, but it does tend to lend some order and clarity to the presentation. The external reforms discussed in the final part include the structuring of the federal income tax laws, the regulation of political activity, and the disclosure and insider trading laws administered by the Securities and Exchange Commission (SEC). As will be seen, many controversies over corporate law reform can be explained as pertaining to fundamental political disagreements. But in a number of important instances, the disputants share the same values and conflict turns on different factual assertions and empiricallytestable hypotheses. The article sorts out when the disputes are of one kind or another, and suggests when a policy consensus can be furthered by additional testing of theories.

By charting a correspondence between concrete reform programs and radically opposing ideals, the article seeks to make the antagonists visible and thereby facilitate comparative assessments of the views of supporters and critics of the corporate form. However, the attempt to construct a typology in order to provide a mapping between reform proposals and ideals in a seemingly undifferentiated political landscape is not without its own difficulties: Generality is obtained only at the cost of simplification, idealization, and abstraction. I hope that in this instance the ventilation of numerous issues within a comprehensive framework will provide more than adequate compensating insight.

I.

A typology of democratic visions of social and economic organization is the most succinct means of conveying the connection between corporate law reform and politics. The analysis I employ consists of ideal types, constructs that are derived from observable reality but 
deliberately simplify and reduce it by selectively accentuating specific features due to their importance. The types represent a theorist's metapolitics, his "conception of political life in the broadest sense," including his ideas concerning the nature of man and society." Before introducing the typology, however, a few words concerning the scope of the analysis are in order. The article attempts to be solely descriptive of political ideals and makes no sustained effort to comment upon several important questions: the internal coherence of particular ideals, their desirability, and problems of implementation. Because these hard questions, whose answers can unmask the noblest aspirations to be grand illusions, are peripheral to my immediate concern, I leave them for another occasion. Furthermore, my approach is ahistorical: My interest is in isolating key elements of the ideals that are at the heart of prominent corporate reform programs. Finally, I am not attempting to generate a new grammar, and the nomenclature should at least resonate if it is not fully familiar. Although the typology does not directly discuss the values that most often concern legal scholars-efficiency, equality, and liberty- these values will be related to the analysis at least by implication.

Two themes underlie my formulation of the parameters that inform political beliefs: organization and community. ${ }^{8}$ A simple matrix constructed from the interaction of these variables distinguishes four contrasting political ideals. The columns of the matrix depict modes of organization-hierarchy and decentralized arrangements. ${ }^{9}$ The rows portray two distinct principles of community-an organic conception of society and an individual-based one. The matrix is therefore polythetic, containing core concerns that are usually not joined: Structural or technical features that describe the mode of economic organization and political decisionmaking are combined with a moral dimension that identifies the principle that can or ought to bind social relationships. Although many scholars consider

7. See H. Pitkin, The Concept of Representation 146 (1967).

8. While these terms have been explored by many scholars, my typology has been influenced most by Sheldon Wolin's analysis of modern political thought in S. Wolin, Politics AND VISION 357-68 (1960), although there are significant differences in our uses of the concepts.

9. Oliver Williamson's work on markets and hierarchies frames my discussion. O. WiLLIAMSON, MARKETS AND HIERARCHIES (1975). My terminology differs from his by including in the decentralized pattern of markets alternative participatory arrangements, such as peer groups. Williamson treats the peer group as a form, distinct from both markets and hierarchies, that is not of great importance in modern production arrangements. Id. at 40-49. I am also using the organizational forms as components of normative theories, whereas Williamson is engaged in a positive analysis of economic institutions. 
the division between organicism and individualism as the fundamental pole, in my view this dichotomy is not sufficiently fine for distinguishing between ideals. ${ }^{10}$ Organizational features are also necessary to specify accurately the variety of contemporary political visions. Moreover, such factors are integral to our context of corporate law reform because the reforms are quite often directed to the structural change of economic institutions.

\section{Organization}

Hierarchy Decentralization

Organicism

Community

Individualism

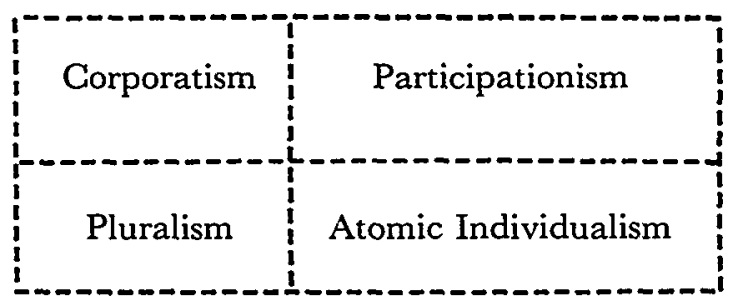

The term hierarchy follows ordinary usage. It refers to an ordered system of integrated activities, quintessentially manifested by large-scale bureaucracies. The vertical stratification and functional specialization of task in such organizations confer order and regularity on social phenomena through the progressive centralization of authority, and thereby provide a means of social control. The term decentralization is meant to convey arrangements that are sustained by either the coordination and information mechanisms associated with markets or the personal relationships of peers.

In the context of business organizations, the choice between hierarchy and decentralization indicates one's perspective concerning the efficiency of production in large-scale firms. By definition, changes in allocations are efficient, or Pareto improvements, if they make everyone better off, or at least someone is better off and no one worse off.

10. A good illustration of the importance of organization is the fate of the Greek citystates. The decentralized democratic ideal of the city-states did not provide a theoretical underpinning for the establishment of a hierarchical overlay, such as a federation of states. This organizational decentralization, however, contributed to the collapse of the political and social system. See R. DAHL \& E. TuFte, Size ANd Democracy 128-30 (1973). If organization is purely a strategic consideration, it is difficult to understand why the Greek political system could not avoid its demise by adopting some unifying hierarchical ordering. Hence, while the divide between organicism and individualism is often treated as the first order question and the organizational component as at best a second order concern, in my analysis they are accorded equal attention. 
A hierarchical vision is premised on the existence of welfare gains from the central coordination of internally differentiated hierarchies. That is, the use of a hierarchy is seen as a Pareto-superior move. More concretely, the learning of the economic literature on the theory of the firm provides an efficiency explanation of the organization of economic activity into hierarchies. It suggests that a command system of organization and the separation of ownership and control can reduce transaction costs and allocate risk among a firm's participants. ${ }^{11}$ In addition, business organizations may foster cooperative behavior when the individually dominant strategy of noncooperation produces inefficient outcomes: By affording individuals with a ready means to guarantee repeated transactions, the firm's permanence has reputation-building effects, which foster the emergence of the more efficient cooperative outcome. ${ }^{12}$ In response to efficiency-based explanations, adherents of the decentralization position take one of two tacks. They challenge the view that hierarchies are in fact efficient organizational forms for production, or they assert that efficiency is neither a desirable nor an important social value. ${ }^{13}$

11. O. Williamson, supra note 9 (reduction of transaction costs); Alchian \& Demsetz, Production, Information Costs, and Economic Organization, 62 AM. ECON. REV. 777 (1972) (indivisibilities in team production create shirking opportunities, which require appointment of monitors who are residual claimants); Kihlstrom \& Laffont, A General Equilibrium Entrepreneurial Theory of Firm Formation Based on Risk Aversion, 87 J. POL. ECON. 719 (1979) (individuals separate into employers and workers because of different attitudes towards risk). In this context, the efficient outcome is not the first best but a constrained Pareto optimum.

12. This result is derived from the folk theorem of repeated games, that more frequent dealings lead to richer opportunities for cooperation. In brief, the payoffs in many business situations may be viewed as a form of the prisoners' dilemma, a game in which noncooperative behavior is individually rational but suboptimal. The cooperative solution emerges in such games only in repeated play, in the absence of the players' ability to write binding contracts or to collude explicitly. A well-known result in game theory is that when such games have an infinite number of plays, there are multiple equilibria, including the desired cooperative optimum. The existence of perpetual firm life under corporation laws may be a means to ensure cooperation. It establishes an infinite horizon for institutional players, and hence makes the cooperative outcome both possible and rational. In addition, if there is only a finite period of play but asymmetric information, the cooperative solution may emerge for some number of plays as a function of reputation-building. See, e.g., Kreps, Milgrom, Roberts, \& Wilson, Rational Cooperation in the Finitely-Repeated Prisoners' Dilemma, $27 \mathrm{~J}$. ECON. THEORY 245 (1982). Although individuals may equally well avoid the dilemma by engaging in mutually repeated transactions, a firm ensures longevity, as it outlives specific members. A useful way to think of this problem in the business context is in terms of consumer uncertainty concerning product quality. See Akerlof, The Market for "Lemons": Quality" Uncertainty and the Market Mechanism, 84 Q. J. EcoN. 488 (1970) (in the used car market, car dealerships provide better warranty of quality than individual sellers).

13. Some contend that the hierarchical organization of work is not strictly a matter of efficiency but of power, the means by which capitalists consolidate and extend their domination over workers, e.g., Marglin, What Do Bosses Do.?, REv. RaD. POL. ECON., Summer 1974, 
To be sure, the distinction between hierarchy and decentralization is blunt, for firms exist within markets and markets within firms, ${ }^{14}$ and markets play an important role in maintaining the efficiency of firm organization..$^{15}$ But the essence of a hierarchical ideal, in contrast to a decentralized one, is substantial delegation of decisional authority. While not all, perhaps not even most, relationships will be hierarchical, in a hierarchical vision many of the key political and economic decisions are delegated to specific members of society. These arrangements are not derived from scholasticism: The usefulness of hierarchy is perceived to be functional and not a matter of divine declaration or blind tradition. The cost of information, among other factors, provides the basis for rejecting the decentralized decision mechanism of direct democracy as unworkable, and for favoring representative government and hierarchical organizations. As a consequence, the master problem for a vision in the hierarchy plane is the agency or representation problem, the problem of how to ensure that delegation is effective, that the agent's incentives are aligned with the principal's desires. This issue of incentive compatibility is the central question for corporate law as well, for it is premised on principal-agent relationships, as shareholders delegate authority to managers.

Whereas the columns-hierarchy and decentralization-are modes of economic or technological organization, the rows-organicism and individualism - contain a dimension with philosophical implications. The individualist position views the individual as the building block for society and attaches to a group no special signiff cance apart from its members. The organic vision, by contrast, is based upon a quest for a holistic community and is distinct from a simple measure of social cohesiveness. It is characterized by a per-

at 60 , while others seem to suggest that the very concept of efficiency is an ideological tool for domination, e.g., Kennedy, Cost-Benefit Analysis of Entitlement Problems: A Critique, 33 STAN. L. REV. 387 (1981). A related strategy is to redefine efficiency to include a notion of class domination, see, e.g., Gordon, Capitalist Efficiency and Socialist Efficiency, MONTHLY Rev., July-Aug. 1976 , at 19. For a persuasive response to the contention that nonhierarchical and hierarchical work patterns are equally efficient, see Williamson, The Organization of Work, $1 \mathrm{~J}$. EcoN. BEHAV. \& ORGANIZATION 5 (1980). In addition, the choice of organization does not turn on who owns the means of production. A hierarchy can be controlled by capitalists or workers, and conceptually no a priori identity exists between ownership and organizational form. See, e.g., Greenberg, Industrial Self-Management and Political Attitudes, 75 AM. POL. SCI. Rev. 29, 32 (1981) (worker-owned plywood firms hire managers).

14. See O. Williamson, supra note 9. Williamson, however, refers to this composite feature at the level of individual firms, and not the society.

15. Fama, Agency Problems and the Theory of the Firm, 88 J. POL. ECON. 288 (1980) (managerial labor market); Manne, supra note 3 (market for corporate control). 
ception of the social collectivity as qualitatively different from, if not transcendent of, its individual members, and verges on transforming the state or group from a means to an end. ${ }^{16}$ Most descriptions of the organic/individualist distinction are not terribly satisfactory because it is difficult to formulate precisely the organic ideal. The trouble may derive from the ideal's association with intellectual movements that were reacting against rationalism and tended to emphasize a direct experiential understanding of reality that defies easy codification. ${ }^{17}$ Some of the problem, however, may be caused by unfamiliarity: Organic theories have had limited influence on mainstream American thought.

The most familiar and useful distinction between organicism and individualism concerns the specification and aggregation of interests or preferences. For the aggregation of preferences is a matter of great importance to democratic theory, insofar as democracy is defined as a method of collective decisionmaking. ${ }^{18}$ In the individualist ideal, it is individual preferences that count, and a core problem is the determination of the decision rule by which to aggregate those preferences. ${ }^{19}$ Individualists contend that the individual knows, and indeed solely knows, his best interests. It is not that the individual is thought to know his interests perfectly, but that he will be a "better and more impartial judge" than others claiming to speak for him. ${ }^{20}$ The organic approach, by contrast, takes certain broad social group-

16. E.g., "Society is not a mere sum of individuals. Rather, the system formed by their association represents a specific reality which has its own characteristics." E. Durkheim, quoted in M. Lessnoff, The Structure of Social Science 76 (1974). More generally, the division between organicism and individualism is similar to the concepts, associated with Ferdinand Toennies, of Gemeinschafl ("community") and Gesellschaf ("society"). Gemeinschafl connotes a holistic community bonded together by shared life experiences and Gesellschaf describes the social relationships of independently contracting individuals. Organicism and individualism may also be identified with the polar theories of the state of Hobbes and Hegel. Whereas Hobbes had a contractarian view of the state, treating it as a creation of individual covenants, Hegel described the state as an organism expressing the transcendent and divine collective (folk) mind.

17. Sec H. Schenk, The Mind of the European Romantics (1966); Barker, Inlroduction to O. Gierke, Natural Law AND THE ThEory OF SOCIETY 1500 TO 1800 (E. Barker trans. 1957); of. R. Lustig, CORPORATE LIBERALISM (1982) (American pragmatists group thinkers reacting against positivism but not rationalism).

18. E.g., W. Nelson, ON Justifying Democracy (1980); W. Riker, Liberalism AgAinst POPUlism (1982).

19. This is easier said than done; the difficulties of doing so are well known. See, e.g., K. Arrow, Social Choice and Individual Values (1951); E. Mishan, InTroduction to NORMATIVE ECONOMICS (1981).

20. F. Knight, Ethics and Economic Reform, in FREEDOM AND REFORM 55, 65 (1982 ed.). In general, paternalistic policies are antithetical to individualism and comprise a central tenet of organic thought, in which the community overrides individual choices. The hard questions 
ings or, in the extreme, the entire state, as the appropriate unit. The preferences of these monolithic social strata, and not of individuals, are coordinated into an expression of the preference of the whole. In organic theory interests therefore belong to collective entities and need not be attached to specific persons. As a result, group preferences are not expected to replicate the individualist weighted

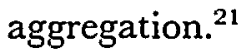

Although organicists do not specify how the group preference is formulated, nor are they particularly concerned with the problem. They perceive the interest of the group to be objectively knowable or discoverable and fixed independently of the shifting, subjective desires of individuals. ${ }^{22}$ Moreover, in organic theories, individual and group interests are perceived to be not in conflict, but rather, in unison with the interest of the whole. Consequently, there is no theoretical necessity for coalition formation or bargaining among groups. Similarly, the interest of the whole is asserted to be at one with the interest of each part. Organicists posit the existence of a public interest or transcendent purpose that is shared by all members of the group and yet independent of and prior to their individual interests. ${ }^{23}$ The individualist approach, however, perceives individual interests to be in potential or actual conflict, usually because of scarcity, and it accordingly emphasizes the need for creating a mechanism for compromise and peace, such as a collective choice rule. From the individualist perspective, no discernible public interest exists apart from the sum of the interests of the community's members. ${ }^{24}$ Unlike organicists, individualists must therefore grapple with

for the individualist involve what responses, if any, should be taken concerning the desires of individuals who are uninformed, misled, or incapable of rational choice.

21. Roberto Unger suggests that individualism is equivalent to the principle of aggregation, in contrast to an organic or collectivist concept of synthesis or "totality." R. UNGER, KNOWLEDGe AND POLITICS 105 (1975).

22. See H. PITKIN, supra note 7, at 168-89 (Burke's organic conception of representation); A. Stepan, The State and Society 31 (1978) (organic-statism). But see R. UnGer, supra note 21 (attempting to create a theory of interests that is neither objective nor subjective).

23. See A. Stepan, supra note 22, at 30. For some organic theorists, this common interest is ethnic or racial. See, e.g., KITA IKkI, NiHon KaIzo HoAN TaIko (1926) (divine Japanese race).

24. A. STEPAN, supra note 22, at 7. Individualists of another era believed a common public interest existed but that individuals would always choose their private interests over that public interest. See H. PITKIN, supra note 7, at 198-206 (discussing 19th century utilitarian concept of representation). Individualists today, however, would understand the phrase "public interest" in terms of the theory of public goods, see note 53 infra and accompanying text, which is connected to individual welfare. 
the pessimistic implications of Kenneth Arrow's famous theorem on the impossibility of a nondictatorial aggregation of individual preferences by a collective choice rule. ${ }^{25}$

Individualism does not, however, reject or question the importance of groups. The crucial distinction, for our purposes, between organicism and individualism is the foundation for a theory of social action, the group or the individual. ${ }^{26}$ An individualist theory explains and justifies actions or outcomes according to either their effect upon individuals or the existence of individual rights, whereas an organic theory legitimates at the level of a collective unit, the group, with less concern for individual rights or consequences. To the individualist, the commitment of organicism to civil liberties and property rights is dangerously attenuated because of the priority accorded to the group, whose interest, in practice, may conflict with the rights or preferences of individual members. ${ }^{27}$ Those organic theorists who acknowledge the awesome coercive potential that can reside in the collective would make the fundamental units for society small groups, where differences in preferences or goals among members could be expected to be less pronounced. ${ }^{28}$

Notwithstanding such qualifications, individualists, no doubt, find unintelligible the concept of either a transcendent group preference or group-based legitimation that is independent of, or prior to, individual rights or consequences. As a result, they might challenge the usefulness of the matrix's organic/individualist pole. But organicism has remained a prominent current in modern political thought, and the typology seeks to describe influential contemporary intellectual positions, not to evaluate their cogency. Even more important, the organic/individualist dichotomy undergirds the competing traditional conceptions or metaphors of corporate law: the contract and

25. K. ARROW, supra note 19; see W. RIKER, supra note 18 (criticizing organic view as undemocratic in light of Arrow's contribution).

26. This distinction may also be viewed as a difference in methodological perspective concerning the proper unit of analysis for social science, the individual or the group. But as a logical matter, methodological individualism need not require a normative commitment to individualism. See Buchanan, Marginal Noles on Reading Political Philosophy, in J. Buchanan \& G. Tullock, The Calculus of Consent 307, 315-17 (1965 ed.).

27. I include as individualists both rights theorists and utilitarians. Rights theorists would direct similar objections to utilitarianism. But although the utilitarian calculus requires a balancing of conflicting individual interests, it is quite different from organicism, which is not premised on maximizing the underlying individual preferences that utilitarians add up.

28. E.g., M. Taylor, Community, ANARchy and Liberty (1982); $q$. R. Abrams, FOUNDATIONS OF POLITICAL ANALYSIS 12 (1980) (choice of decision rule irrelevant for small homogeneous groups). 
concession theories. ${ }^{29}$

The contract approach regards the corporation as a shell or form created by consenting individuals. A firm is a nexus of explicit and implicit contracts, facilitating the implementation of the contracting parties' wishes. The concession view treats the corporation as an entity sui generis, something quite different from its individual parts, with an independent social and political life. According to this perspective, all corporate rights are privileges granted by the state. As a consequence, the concession approach is perceived to support more extensive regulation of corporations than the contract position. ${ }^{30} \mathrm{Al}-$ though this simply restates the current interpretation of doctrine, it should be noted that as a purely abstract matter, it need not be so. The concession theory's endowment of the corporation with an independent life could conceivably imbue it with inviolable rights and thereby serve to restrict regulatory efforts. Similarly, depicting the corporation as a species of contract could signify that it lacked the rights that inhere in individuals and correlatively place limits on the state's regulatory authority. These possible alternative lines of analysis underscore the frequently repeated contention that doctrine is malleable and meaningful only when placed in a normative framework. Yet the concession thesis is persistently paired with greater government regulation.

The organic/individualist dimension of the matrix sheds light upon this common association of the corporate law metaphors with specific regulatory policies despite an apparent open-ended relationship. A corollary of individualism's view of the individual as the fundamental analytical unit is a theory of the corporation as a series of contracts between individuals, for organizations serve solely to further the ends of the participants and have no independent or transcendent meaning. In the organic perspective, however, the elemental units are groups of individuals and the political community is perceived to be a holistic organism that transcends the individual parts. Such a theory fits comfortably with the concession approach to the corporation as a discrete and unique entity independent of its individual members. ${ }^{31}$ It also identifies a source of the persistent coupling of the concession view and greater regulatory authority, namely, the priority organic thought accords collective in-

29. See generally R. Hessen, In Defense Of THE CoRporation (1979).

30. Id.

31. Alfred Stepan includes a concession theory of association as a fundamental component of organic-statist political thought. A. STEPAN, supra note 22, at 28, 37-38. 
terests over the goals of individuals and subunits. The communitybuilding features of the matrix therefore provide some insight into the remarkable consistency with which the legal metaphors are used in support of specific policies: their connection to political positions. As points of reference, organicism and individualism enable us to link the corporate law discussion to an ongoing political discourse with far-ranging normative implications.

Corporatism. The ideal that emphasizes hierarchical organization and an organic conception of community I term corporatism. The corporatist universe is a vertically segmented system of complementary and interdependent social units in which the hierarchical organizational arrangement of the business corporation is fundamental. The key structural feature is a monopolistic representation of interests. According to a leading authority on corporatism, Philippe Schmitter, it is a "system of interest representation in which the constituent units are organized into a limited number of singular, compulsory, non-competitive, hierarchically-ordered, and functionally differentiated categories, recognized or licensed (if not created) by the state."32 These officially sanctioned guild-like organizations are granted representational monopolies in their respective spheres of operation "in exchange for observing certain controls on their selection of leaders and articulation of [interests]." ${ }^{33}$ In addition, the polity is viewed as a smoothly functioning organic unit in which discordant interests are quelled by the development of communal ties. ${ }^{34}$ This is attained by the state's close association and coordination with the monopolistic functional units, and a vision of society as a distinct spiritual community. Indeed, the spiritualism of an organic commu-

32. Schmitter, Sill the Century of Corporatism?, in THE NEw CORPORATISM: SOCLALPolimical Structures in the Iberian World 85, 93 (F. Pike \& T. Stritch eds. 1974); see also Kaufman, Corporatism, Clientelism and Partisan Confict, in AUTHORITARIANISM AND CORPORATISM IN LATIN AMERICA 111 (J. Malloy ed. 1977). Schmitter uses corporatism soley as a positive construct, whereas I am using it to describe ideals.

33. Schmitter, supra note 32 , at 94 .

34. Panitch, The Development of Corporalism in Liberal Democracies, 10 COMP. POL. STUD. 61,61 (1977); see R. BOWEN, German TheORIES OF THE CoRporative STATE (1947); M. ELBOW, FRENCH CORPORATIVE TheORY, 1789-1948 (1953); C. SCHMIDT, THE CORPORATE STATE IN ACTION (1939) (Italian corporatism); H. WIARDA, CORPORATISM AND NATIONAL DEVELOPMENT IN LATIN AMERICA (1981). Schmitter's definition of corporatism is restricted to the organizational features described in the text and does not include organicism largely because he believes that organicism supports a variety of organizational forms that are not necessarily corporatist. See Schmitter, supra note 32, at 91 . This contention does not conflict with my approach because in my definition the organic component is connected to the specific organizational features that Schmitter details. 
nity is a central element in the corporatist vision. It binds the functionally specialized parts into a greater whole, ensuring the harmony of the system. The overriding goal is the destruction of politics, that is, the absorption of the political realm into the social, to achieve a unified society-state, free of divisive conflict among groups.

In the corporatist vision, each individual occupies a niche in a unified social system. The dominant metaphor of society as an organism reinforces the individual's identification with a holistic community, while advancing a complementary objective, the rediscovery of spiritual values that are thought to be lost in a market economy and its perverse emphasis on the satisfaction of individual desires. In addition, because social arrangements are adopted to achieve a collective objective and not to satisfy individual preferences, corporatism supports economic policymaking by central planning, which stresses precise and deliberate societal design rather than reliance on allocations determined by markets. An ineluctable consequence of the highly ordered and planned society that emerges from the conjunction of hierarchic and organic concerns is a deemphasis on individual liberty as a value.

The political ideal of corporatism is distinct from fascism, and it is a mistake to consider them interchangeable. Identifying two variants, state and societal corporatism, should dispel confusion. ${ }^{35}$ In state corporatism, the authoritarian version, the functionally specialized and vertically stratified organizations that are the elemental units are created unilaterally by government. In societal corporatism, the nonauthoritarian mode, corporatist organizational arrangements are not imposed by the state but are envisioned to emerge naturally, though subject to state direction and control. The corporatist theory developed by the Rumanian statesman Mihail Manoilesco is an example of a vision of state corporatism, whereas the writing of John Maynard Keynes has glimmerings of the aspirations of societal corporatism. ${ }^{36}$ Furthermore, organization of society in an organic hierarchy need not result in a completely centralized state as in totalitarian systems. As indicated by the diversity of views expressed by corporatist thinkers, a corporatist polity may consist of a federation of hierarchies that are each separate organic wholes, or of

35. Schmitter, supra note 32 , at 105,126 ; see A. STEPAN, supra note 22 , at $48-52$ (distinguishing between corporatism and fascism).

36. Schmitter, supra note 32, at 117-25 (discussion of Manoilesco) and 108-13 (discussion of Keynes). 
one overarching, fully integrated hierarchy. ${ }^{37}$

The corporatist political ideal can be most lucidly illustrated by the views of an important American corporate law scholar, Adolf Berle. ${ }^{38}$ The organizing principle of Berle's vision is not a market system but the hierarchical corporation. Detailing the historic shift in market structure from numerous small competing producers to oligopolistic competition, he hailed the dethroning of the "market gods" in favor of an economy controllable by state directive. ${ }^{39}$ His descriptive account parallels the prescriptive: He asserts that the giant corporations populating this new oligopolist universe are not simply one form of social organization but should be recognized as the dominant institution, which will replace the nation state, just as the latter had replaced the Ghurch in the Middle Ages. The corporation is conceived as the central social unit, and corporate operations and planning are to be coordinated by government agencies and industry associations. ${ }^{40}$ In addition, based on his empirical research with Gardiner Means on internal corporate structure, Berle reconceptualized the manager's role to be that of a disinterested public servant, a role that could provide the social stability necessary for the attainment of the corporatist ideal. To this end, a persistent theme in his writing is the transformation of businessmen into politicians who could orchestrate society by harmonizing the needs of four constituencies, suppli-

37. Compare M. ELBOW, supra note 34, at 78, 198 (French corporatists' decentralized vision) with T. IsHIDA, MEIJI SEIJI SHISOSHI KENKYu 21-23, 67-68 (1954) (centralized social organicism of Japanese family-state) and Schmitter, supra note 32, at 120-25 (centralized vision of Manoilesco).

38. Cf. Draper, Neo-Corporatists and Neo-Reformers, 1 NEw POL. 87 (1961) (describing Berle as a neo-corporatist); Gilbert, James Bumham: Exemplary Radical of the 1930s, in A New HisTORY OF LEVIATHAN 206, 210-12 (R. Radosh \& M. Rothbard eds. 1972) (Berle's work part of American collectivist discourse). Berle's views were not idiosyncratic: The progressive movement of the early 1900's and the managerialist school of the 1940's and 1950's were essentially corporatist. See 1 A. LINK \& W. CaTTON, AMERICAN EPOCH: A History OF THE UNITED STATES SiNCE THE 1890's 122-23 (1963) (progressive business policies at variance with individualistic tradition); S. WOLIN, supra note 8 (discussing organic views of managerialists such as Philip Selznick and Peter Drucker).

39. E.g., A. BERLE, POWER 157-216 (1967).

40. Just as Berle's celebration of large firms as social building blocks is a common theme of corporatists, his vision of industrial and social organization in a limited number of vertically segmented corporations is a staple component of corporatist theories of the state. See R. BOWEN, supra note 34, at 1-3, 8-10, 215 (German pyramid of trades and professions); $M$. ElBOW, supra note 34, at 14-16, 110-12, 126-28, 143-47, 179-90 (French autonomous corporatively-organized industry associations); KrTA IKKI, supra note 23, at 4-5, 54, 115 (Japanese family-state); T. IsHIDA, supra note 37, at 21-23, 67-68 (same); C. SCHMIDT, supra note 34, at $57-67$ (Italian pyramid of syndicates). 
ers, customers, employees, and the outside community. ${ }^{41}$ In keeping with that aim, he championed a reworking of the traditional view of property rights in the corporation by contending that the shareholders should not be characterized as the firm's owners. This attenuation of the residual claimant's property rights is common to the corporatist approach. The quest for social cohesion focuses on the professional managers' successful administration of these new quasipublic bureaucracies and ignores shareholder interests. Accordingly, corporate managers, likened to civil servants, are envisioned to further selflessly the goals of the community rather than their personal desires. $^{42}$

Despite very obvious corporatist features in his writings, Berle does not articulate a sustained organic view. While the corporate unit is essential to Berle, it is rarely expressly analogized to an organism as is common in the continental literature. More important, Berle does not draw upon any ethnic or nationalist metaphors, as do other corporatists, to create the spiritual basis that secures the unity of the whole. In his work there is no explicit theory of harmony, no overarching group-legitimating explanation that guarantees the spiritual cohesiveness that is so important to corporatists. The one exception is the abstraction of the corporation itself.

Berle's writing is replete with a religious imagery of the corporation that could provide the necessary systemic glue for a corporatist vision. For instance, throughout The Twentieth Century Capitalist Revolution he refers to the modern corporation as the "collective soul" and the "conscience-carrier of twentieth century American society." ${ }^{\text {"43 }}$ Significantly, the final chapter is entitled "Corporate Capitalism and the City of God." In addition, to the extent that

41. A. Berle, Power Without Property 2-3, 8 (1959); A. Berle \& G. Means, supra note 2 , at 356 .

42. Prior to the publication of his mature work, in a celebrated debate on corporate responsibility with Dodd, Berle took a position that he subsequently retracted. See Berle, Foreward to The CoRporation IN MODERN SOCIETY xii (E. Mason ed. 1959); Werner, The Berle-Dodd Dialogue on the Concept of the Corporation, 64 Colum. L. REv, 1458 (1964). He contended that managers were fiduciaries for shareholders, but not for pluralist reasons. Although he asserted that the only means for ensuring that managers would not act selfishly was to indicate clearly to whom they were responsible, he found the term "public" too imprecise to provide an adequate guide. He repeatedly stressed that managers should follow policies that served the interests of both the shareholders and the "whole corporation." Berle, Corporale Powers as Powers in Trust, 44 Harv. L. Rev. 1049 (1931).

43. A. Berle, The Tiventieth Century Capitalist Revolution 148 (1955). In The Modern Corporation and Private Property, Berle and Means do refer to the corporation at one point as an "economic organism." A. BERLE \& G. MEANS, supra note 2, at 313. 
managers embody the public interest in the performance of their duties, their directives to the enterprise will not be the same as those emanating from the preferences of shareholders or any other definable group. This role is evocative of an organic conception of interests: Corporate managers are considered able to determine independently the public interest that they are to implement. ${ }^{44}$ Berle's vision therefore relies on a religious symbolism of the corporation and the implicit role of the corporate manager as the oracle of the public interest, to foster the requisite spirit of community.

The nuance of the organic metaphor used by Berle, in contrast with that of continental corporatists, may be a function of what is termed American exceptionalism, the unique character of American nationalism, that takes the form of a civil religion expressed in political, rather than cultural or territorial, ideals. ${ }^{45}$ By glorifying corporations- clothing them in quasi-religious imagery and identifying managers with a broad public interest-Berle's program is in keeping with the exceptionalist view of the American creed as a religious politics and not a cultural nationalism. From this perspective, Berle's religious metaphor, as well as his belief in public interest managers, is a vision as organic as could be expected of someone engaged by American politics. $\mathrm{He}$ is a corporatist in the American grain.

Atomic individualism. The political ideal whose core components are the opposite of those of corporatism I call atomic individualism. This ideal, which stresses the individual as the centerpiece of political and social life, finds its organizational paradigm in market transactions, which depend upon voluntary and consensual relations between individuals. In general, atomic individualism corresponds to an anarchist libertarian vision. Its proponents characteristically de-

44. The public interest is further invoked as a restraint on managers to ensure that they perform their role of disinterested civil servants properly. A. BERLE \& G. MEANS, supra note 2, at 110-16; A. BERLE, supra note 43, at 39-44. In addition, Berle's belief in the efficacy of economic planning and his use of the concession view of corporations to support government regulation, see Berle, Constitutional Limitations on Corporale Activily-Protection of Personal Rights From Invasion Through Economic Power, 100 U. PA. L. REV. 933 (1952), are features best associated with organic and not individualist thought.

45. S. Huntington, American Politics: The Promise of Disharmony 23-25 (1982). The consensus view of American history, see id.; L. HARTZ, THE LIBERAL Tradition IN AMERICA (1955), suggests another explanation for the distinct difference between Berle and other corporatist intellectuals concerning the mechanism of social cohesion. According to this interpretation, there has been widespread agreement among Americans upon values and goals. Unlike his counterparts abroad upon whom class and social divisiveness would have had a more powerful and formative influence, Berle would therefore not need to emphasize or construct a theory of social harmony. 
sire decentralization on a highly individualistic basis and are hostile to even a night-watchman state.

The atomic individualist is most concerned with individual liberty and perceives hierarchies, whether public or private, to be instruments that severely threaten or restrict that liberty. Perhaps most representative of this position is the novelist Ayn Rand, whose work celebrates the lone individual who bucks organizational life. ${ }^{46}$ A more difficult and ambiguous figure whose proposals share a common concern of the atomic individualist ideal is the economist Henry Simons. In attempting to develop what he termed a "positive program for laissez faire," Simons viewed large organizations as the "enemy of democracy." ${ }^{27}$ He suggested a series of antitrust, tax, and corporate regulatory policies to dismantle big corporations. Although reluctant to lose any of the economies of scale of large hierarchical organizations, he was skeptical of the extent or existence of such benefits and desired to break up big corporations into tiny bits. The primitive antitrust policy espoused by Justice Brandeis in Liggett Co. v. $L e e^{48}$ conveys a similar attitude. Simons and Brandeis are not, however, full-fledged advocates of the atomic individualist position: While Simons and Brandeis disdained private hierarchies, they both foresaw different, yet important, roles for the state.

The difficulty in finding exemplars of the atomic individualist ideal should not be too surprising. Atomic individualism's extreme animosity towards hierarchy makes it a null set in the context of corporate law reform proposals. In brief, holders of this vision of social and economic arrangements cannot be expected to express much enthusiasm for making corporations operate more effectively or for specifying a particular corporate form because hierarchical organizations are not a part of their ideal.

Pluralism. Although the third ideal type, pluralism, like atomic individualism, is associated with markets, it joins hierarchical and individualist concerns for it recognizes and values the benefits that can be attained from organization. The pluralist ideal emphasizes the spontaneous formation and proliferation of numerous independent units of interest representation that interact competitively, in

46. E.g., A. Rand, The Fountainhead (1943).

47. H. Simons, A Positive Program for Laissez Faire (1934). The ambiguity in Simons' work was well put by Harold Demsetz: "You can paint [Simons] with different colors, depending on how you read him." Demsetz, The Fire of Truth: A Remembrance of Law and Economics at Chicago, 1932-1970, 26 J. L. \& ECON. 163, 178 (E. Kitch ed. 1983).

48. 288 U.S. 517, 548-49, 574 (1933) (Brandeis, J., dissenting). 
contrast to the vertically extended corporatist organizations that hold monopoly positions in the representation of interests and are subject to substantial state direction and control. ${ }^{49}$

Pluralism does share with corporatism some fundamental structural features that do not appear in either of the decentralized models of organization, including the growth of permanent, specialized administrative staffs, the "expansion of functionally differentiated" interests, and the "importance of formal associational units of representation." 50 However, in a pluralist world there are multiple centers of decisional authority that compete with one another, and the organizing principle is still the individual. This is evidenced by the individualistic concept of representation that pluralism embraces: Organizations are competing aggregative devices with no independent existence. Furthermore, individuals are posited to belong to a number of such groups.

The multiplicity of organizations representing different individual interests is as important as markets for organizing activity in a pluralist polity. The pluralist emphasis on organizational diversity and competition is derived from a concern for individual choice. Organizations are the foundation for what is often referred to as interest group politics, and are believed to be indispensable for safeguarding individual rights. Pluralist decisionmaking entails compromises between competing constituent groups, each of which represents the aggregated interests of its members. Competition and conflict are essential to the ideal because shifting coalitions and the unfettered entry and exit of organizations in markets and politics are thought to ensure that no one group or individual's interest will be systematically obstructed or excluded.

Just as there is competition among organizations in the representation of interests, the pluralist state is also internally engaged in a competitive process by means of a federal system ${ }^{51}$ and a sharply enforced division between public and private spheres of action. Corporatism would attenuate this private space in its effort to fuse society and state into one domain. It also eliminates or deemphasizes competition among political subentities. Pluralism thus recognizes a nec-

49. Schmitter, supra note 32, at 97 . See A. STEPAN, supra note 22, at 17 n. 36 (stressing state's role in forging structured interactions among existing interest groups in societal corporatism).

50. Schmitter, supra note 32, at 96.

51. See D. Yates, Bureaucratic Democracy 10-17 (1982) (identifying pluralism with federalism). 
essary but more limited role for the state than corporatism. ${ }^{52}$ In addition, because of its core belief in the sovereignty of individual choice and the importance of competition to promote that end, pluralism rejects central economic planning and favors the use of markets and an incremental approach to social change, which permits experimentation with low adjustment costs for errors in judgment. The theoretically tough questions for the pluralist principle of consumer sovereignty concern the actions of individuals who are thought to lack the capacity for rational choice, such as children, the insane, and the infirm.

The pluralist view of the state is linked to the concepts of externalities and public goods, whose characteristics of nonrivalness and nonexcludability in consumption cause markets to operate imperfectly and hence define a role for government. ${ }^{53}$ By ensuring the adequate provision of public goods, enforcing private efforts at cooperation, and enacting legal rules that aid or force parties to internalize externalities-in short, by correcting market failures-the state furthers the realization of individually optimal outcomes. An analogous public goods explanation can be given for the use of corporate firms. Although a firm's product is a private good when sold in the market, the members of the corporation produce a public good for their group. The economic surplus that is generated by the cooperation of individuals in production has a common property resource or public goods aspect, which is associated with informational economies of scale. Specific information is necessary in the production of any commodity, but because information is a public good it will not be adequately supplied by the market. A corporation joins together in a nonmarket transaction the individuals for whom that information is relevant, and therefore mitigates the public goods problem. In this way, firms are a rational mechanism for developing and exploit-

52. Nedelmann \& Meier, Theories of Contemporary Corporatism: Static or Dynamic?, 10 CoMP. Pol. STUD. 39, 40 (1977) (emphasizing difference between corporatism and pluralism is active role for state in former); A. STEPAN, supra note 22, at 7-47 (unlike liberal-pluralist theory, organic-statist tradition used to rationalize corporatism has strong interventionist state).

53. E.g., R. ABRAMS, supra note 28 , at 11 ("In fact, the Western liberal tradition rests on the notion that the main function of government is to prevent what economists call negative externalities, and what political theorists and philosophers would call a denial of rights, or harm."). A public good has the characteristics of nonrivalness or jointness of supply and nonexcludability in consumption. Nonrivalness occurs when the provision of the good to one individual does not affect or limit the consumption of that good by any other individual. Nonexcludability occurs when it is impossible or prohibitively costly to exclude anyone from consuming a good. Given these features, the supply of public goods may be inadequate because it is in an individual's interest not to contribute to finance the good's provision as the benefits may be obtained without having to share the costs. 
ing information, which could not be obtained by decentralization, ${ }^{54}$ and they thereby increase the welfare of their members.

In sum, a market-correcting function is at the heart of the pluralist theory of the state: Coercion is necessary to guarantee that individuals attain their optimal consumption bundles. The thorny question, which is peripheral to the business firm context, is the boundary problem concerning the limits of justifiable coercion, a concept that depends, in part, on the precision of the notion of a demonstrated market failure. It also depends upon the extent to which redistributive goals are to be implemented, a policy question that is distinct from the need to remedy production externalities and provides a second role for the state within a pluralist framework. Based on their position concerning the relative importance of these two goals and the degree of state involvement necessary to resolve them, pluralists roughly divide between two polar ideals: the welfare state and the minimal state.

The administrative apparatus of the pluralist welfare state has its source in the public goods/externalities theory of government: State regulation of private activities is justified on grounds of market failure. In addition, in keeping with an individualist perspective, the theory of the welfare state is based on notions of individual entitlements. It emphasizes a political judgment that each member is entitled to a specified minimum bundle of rights or subsistence level, ${ }^{55}$ which the operation of markets may not provide. Moreover, the importance of individual entitlements in the welfare state suggests that even if there are no externalities so that markets are efficient, a role for government would remain beyond the enforcement of property rights: adjusting the distributive, rather than the allocative, consequences of markets. A minimum level of income is deemed necessary to secure for each individual the freedom of choice and equality of opportunity that is a prerequisite for the attainment of self-fulfillment, historically an important objective of individualist theories.

54. See K. ARROW, supra note 6 .

55. See H. Wilensky, The "New Corporatism," Centralization, and the WelFARE STATE 8-9 (1976); Grey, Properly and Need: The Welfare State and Theories of Distributive Justice, 28 STAN. L. REV. 877 (1976). When it comes to entitlements, the welfare state's function need not be solely redistributive: It may also take the form of compelling people to insure themselves. See generally Y. AhARONI, THE No-RISK SOCIETY (1981). It should be noted that there are markedly different formulations of the characteristics of a welfare state. Sweden, for instance, is commonly thought of as a welfare state, see, e.g., N. FuRNISS \& $T$. Tilton, The Case for the Welfare State: From Social SecurtTy to Social EqualITY 122-52 (1977), but in my typology it would more closely approximate a corporatist than a pluralist ideal. 
The ideal of a welfare state should not be confused with corporatism. In principle, the welfare state regulates industry solely to ensure the internalization of production externalities. In a corporatist polity, however, much greater collaboration between private and public enterprise is desired. Collective goals, achieved by central economic planning, take precedence over the individual liberties that the pluralist polity attempts to protect. By contrast, a welfare state provides public goods and/or transfers income between individuals, and does not extensively coordinate the production of private goods. In theory, the mitigation of externalities and the redistribution of income call for far more limited state activity than corporatism. But in practice, given the extensive government apparatus that the welfare state can generate, this version of pluralism could shade into corporatism, as individual rights and liberties are traded off by legislators and bureaucrats in favor of collective concerns and the maintenance of social peace.

The possibility of the erosion of civil liberties by a gradual shift towards corporatist arrangements through the enlargement of state activity is at the bottom of the schism among pluralists. Pluralists who deemphasize the public goods problem contend that private provision will generally produce an acceptable level of public goods. They seek instead to guard against what they believe to be a more pressing danger, a leviathan state. These pluralists therefore see the need for only a minimal state, to secure the purest of public goods, such as national defense. They reject an expansive view of governmental functions, including activities that have become important tasks for the welfare state, such as insurance and redistribution. While all pluralists share pragmatic concerns over the effect of income redistribution on incentives for production, minimal state pluralists tend to perceive it as a more serious problem. For this and more subtle reasons involving notions of individual rights and deserts too esoteric to discuss here, they oppose a significant redistributive role for the state. Insofar as disagreement centers only upon differing perceptions of the scope of the public goods problem, the divergence in perspective between welfare and minimal statists tracks the division in the economics literature between the more traditional Pigovian view, that the production of externalities requires government to assist the working of the market's invisible hand, and the Coasian view, that bargaining among private parties over the production of an externality generally produces the optimal social outcome. 
Although pluralists sharply disagree over the desirable scope of government activity, they are in fundamental accord on the need for private hierarchies, which are our primary concern. Both minimal and welfare state pluralists value decisively the efficiency gains from corporate organization in the nonpublic sector, the powerful ability of firms to augment individual welfare. The minimal state position on private hierarchies is not inconsistent with its uneasiness towards government. Support for the private corporate sector is founded on the judgment that because of the incentive effects of markets, the efficiencies of organizational form vary significantly between public and private enterprise. The minimal state pluralist therefore favors organizational arrangements that differ according to the sphere of action, public or private. In this respect, the position pushes to the limit the pluralist separation of state and society: The differentiation between public and private space is secured by distinguishing between the proper mode of organization in those domains.

The views of a sophisticated and eloquent advocate of the minimal state position, Friedrich Hayek, should help in clarifying the disagreement between minimal and welfare state pluralists. For Hayek does not dispute the assessment that the provision of public goods is a valid state function. Rather, he objects to the exclusive or monopolistic provision of public goods by the federal (central) government. This approach leads him to identify local government as the more appropriate actor in the public goods context. ${ }^{56}$ As a matter of taste, however, he prefers the voluntary private provision of public goods wherever possible, and he stresses that the government's proper involvement is the financing, rather than administering, of such services. $^{57} \mathrm{He}$ considers public bureaucracy-the expansion of the administrative state and its delegation of decisional authority-a threat to individual liberty. ${ }^{58}$ In addition, while supporting the state's assurance to all individuals of a minimum level of income, he opposes the strongly egalitarian redistributive component implicit in the institutional arrangements of the welfare state. ${ }^{59}$ Yet in the private sector, he unambiguously endorses the use of the corporate

56. F. HAYEK, The Constitution of Liberty 263-64 (1960) [hereinafter cited as F. HAYEK, Constitution]; 3 F. HAyek, LAW, Legislation AND Liberty 41-46 (1979) [hereinafter cited as 3 F. HAYEK, LAW].

57. 3 F. HAYEK, LAW, supra note 56 , at $42,46$.

58. F. HAYEK, CONSTITUTION, supra note 56, at 258-62.

59. 3 F. HAYEK, LAW, supra note 56 , at 55 . 
form. ${ }^{60}$ Although there are more fervent adherents of a minimal state than Hayek, he typifies the perspective in seeking to rein in only public hierarchies.

Hayek's position also highlights the difference between minimal state pluralists and atomic individualists. Their visions diverge over which factors constitute the greatest potential harm to individual liberty. Atomic individualists concur with the minimal state pluralist's objection to an expansive state but reject, or are skeptical of the pluralist aim to realize the efficiency gains from organization in large private corporations. They perceive, instead, any large-scale hierarchical organization to threaten and impinge upon individual liberty. To minimal state pluralists, however, the state is the danger. Private hierarchies are not menacing for two reasons: Corporations are the outcome of voluntary consensual relations, and they do not possess a monopolistic presence. Because of these crucial factors, an individual need not remain a captive party to a private hierarchical arrangement-he can exit fairly easily from one organization to another. By contrast, the state's unrivaled position is the essence of an ability to coerce and the antithesis of liberty. ${ }^{61}$ Atomic individualists, nonetheless, do not distinguish between the state and private firms. They find hierarchical relationships so inherently coercive that they either deny the possibility that individuals could freely consent to join hierarchies or, alternatively, insist that individuals should not consent, believing that creativity and individuality are stultified and wither in such organizations. ${ }^{62}$

Participationism. The upper right position in the matrix, the nonhierarchical and nonindividualistic view of the polity, is labeled

60. Id. at 77-83. Unlike atomic individualists, Hayek opposes corporate bigness only if it prevents competition; he does not object to firm size or monopoly power per se.

61. See F. HAYEK, Constitution, supra note 56, at 262.

62. Another handy distinction between minimum state pluralists and atomic individualists is the decision rule each group deems most appropriate for reaching a collective choice. The atomic individualist would require unanimity, a system of veto voting, for all decisions, in keeping with a primary concern for individual liberty and the market paradigm, in which both parties to the transaction must agree for exchange to occur. Minimal state pluralists, however, view unanimity as an ideal or benchmark and not as a mandatory choice rule, given the costs of decisionmaking. They consider it, at best, the appropriate rule for the constitutional stage, whereas for ordinary collective choices they would accept majority rule. See J. Buchanan \& G. Tullock, supra note 26; J. Buchanan, The Limits of Liberty: Between ANARCHY AND LEVIATHAN (1975). For an explanation of the importance of unanimity in the decentralized vision, see Mack, Liberty and Justice, in JUSTICE AND ECONOMIC DISTRIBUTION 183, 185-87 (J. Arthur \& W. Shaw eds. 1978). 
participationism. ${ }^{63}$ The participationist ideal is organized around small nonhierarchical groups that display, as the name denotes, high levels of member participation in all decisions. This vision is organic and not individualist because it perceives the group, which may be the entire community, as the elemental political and social unit. The primary goal is the decentralization of decisionmaking. Many of the adherents of this position have an antipathy towards the prototypical decentralized decisionmaking mechanism, the market. But this is consistent with their principal objective. Individuals enter the market on a separate and independent basis, taking the decisions of others as given, whereas for participationism, decisionmaking must be undertaken jointly and intimately by the group's members.

The crucial element of this vision, the demand for group participation in decisionmaking in all aspects of life, involves the convergence of an organic perspective with a decentralized structure that obliterates the separation of public and private spheres of action. The political ideal of participationists is even more explicitly organic than the work of Rousseau, which prefigures modern participationist thought by rejecting the mediating institutions of representative government and favoring decentralized direct democracy. ${ }^{64}$ Contemporary theorists advocate an expansive total conception of the political that includes all spheres of individual activity, such as the workplace, whereas Rousseau countenanced a private space for his citizens. ${ }^{65}$ This total conception of politics recognizes no distinction between public and private domains, as individual interests are subsumed by those of the group.

In conjunction with its focus upon the need for wide-scale participation in all areas of decisionmaking, participationism tends to emphasize equality rather than individual choice. To critics, it is dangerously antidemocratic because a holistic approach to decisionmaking ignores the potential, if not common, conflict between an individual's preference and a group's choice. Participationists, in contrast to corporatists, attempt to parry such concerns by proposing to organize the polity into small groups, in which the desires of the

63. This term was coined by a proponent of the vision. R. MASON, Participatory AND WORKPLACE DEMOCRACY 196 (1982).

64. See A. Levine, Liberal Democracy: A Critique of Its Theory (1981); R. DAHL, After the Revolution? 79-80 (1970).

65. But see W. Bluhm, Theories of the Political System: Glassics of Political Thought \& Political ANALysis 338-340 (3d ed. 1978) (passage in Rousseau's work implying legitimate realm for private interests is less important than passages embracing totalitarian conception of the political). 
individual members should be quite homogeneous. Yet liberty is still accorded far less weight than equality in this ideal. Although the welfare state does have an egalitarian component, its hierarchical organization and individualist goals render it incompatible with the participationist program.

A prominent advocate of the participationist position, Carole Pateman, has articulated as a societal ideal a "decentralized federation of participatory councils." "The polity is envisioned as a "multiplicity of participatory or self-managed units" in a political space enlarged beyond the traditional pluralist view to include most areas of social life. Industry, for example, becomes a "political system" and the prime focus of concern, because nearly all individuals spend a significant proportion of their time at work. The workplace is to be reorganized along participatory lines and its authority structures are to be decentralized to permit workers to engage in firm decisionmaking with power and frequency equal to that of their employers. ${ }^{67} \mathrm{An}$ other good example of participationism that is less directly addressed to corporate life is Gar Alperovitz's society of autonomous communities. ${ }^{68}$ The Israeli kibbutz serves as the model. Alperovitz would replace the old left ideal of a centrally planned hierarchical state with an "organic, diversified vision" of "thousands of small communities, each organized cooperatively, each working out its own priorities." 69 Neither workers nor employers, but the entire community, defined territorially by geographical contiguity, controls production decisions and divides tasks and outputs among group members. The ideal is a decentralized political organization consisting of virtually autarkic small groups. Alperovitz refers to his program as a "pluralist commonwealth," but this expression is connected to his two central concerns, decentralization and the cooperative use of wealth to benefit the members of the community as a whole,${ }^{70}$ concerns that identify the participationist and not the pluralist ideal.

66. Pateman, Sublimation and Reification: Locke, Wolin and the Liberal Democratic Conception of the Political, 5 POL. \& SOC'Y 441, 466 (1975).

67. C. Pateman, Participation and Democratic Theory (1970). In a well-known critique of pluralism, Peter Bachrach advocated a position similar to Pateman's, expanding participation in corporations, which are perceived as political institutions. P. BACHRACH, The Theory of Democratic Elitism: A CRITIQUe 93-106 (1967). Robert Dahl is also sympathetic to the participationist position. R. DAHL, supra note 64 , at $130-40$; R. DAHL, Dilemmas of Pluralist Democracy (1982).

68. Alperovitz, Notes Toward a Pluralist Commonwealth, in S. LYND \& G. ALPEROVITL, Strategy and Program: Two Essays Toward A New American Socialism 49 (1973).

69. Id. at 66.

70. Id. at $68-69$. 
Implications of the typology. Although the analysis of ideals has intrinsic interest, they are introduced in this article for their power as guides for characterizing corporate law reform. Each ideal demands corporate organizational arrangements that are isomorphic with its envisioned ordering. For instance, the organic unity and social cohesion essential to the corporatist ideal require corporations that operate cohesively as miniature replicas of the polity, the atoms or microcosms reproduced on a large scale in the corporatist state. Corporations provide individuals with a preordained social niche, just as they have a clearly defined position in the chain of authority comprising the state. This coordination of individuals into one unified whole is to foster the development of a spiritual-like attachment to an organic community. If the corporate form was not assimilated to the organic orientation of corporatism, then the monopolistic coordination and stabilization of societal activities identifying corporatist arrangements would be difficult to sustain, and the ability of the system to stem social divisiveness would be diminished. For such organizations are thought to nurture individuals and provide the key connection to the state. Hence, a specific institutional pattern is a necessary and sufficient condition for stability in the corporatist ideal.

Similar conditions of structural homology are contained in the other ideals. Participationism demands that its goal of participation be extended to the internal arrangements of corporations. Adherents of this vision maintain that the decentralization of corporate organizations, involving direct participation in firm decisionmaking by all members, is a prerequisite for establishing fully participatory political structures. ${ }^{71}$ For a decentralized communitarian system to work, societal units, being predicated on the economic and political equality of their members, must possess attributes of smallness and sameness. ${ }^{72}$ These characteristics cannot survive within large hierarchical corporations, whose dynamics undermine and destabilize the egalitarian basis of social relationships.

Specifying the pluralist corporate form is the most complex task, for pluralism does not demand a particular organizational pattern. Rather, pluralist democracy is conditioned upon the existence of numerous autonomous organizations. ${ }^{73}$ Such organizations curb state domination and thereby safeguard liberty, by serving as a counter-

71. See, e.g., R. MASON, supra note 63; C. PATEMAN, supra note 67.

72. See, e.g., M. TAYLOR, supra note 28.

73. See R. DAHL, supra note 67. 
weight to an expansive public bureaucracy and providing a clearly specified realm of private activity. Because pluralism emphasizes diversity and conflict, competing institutional arrangements that mix decentralized and hierarchical forms are fully compatible with the ideal, but only if they are the product of private contracting. The pivotal factor for pluralism is that no particular business form should be imposed by the state. Institutional diversity guarantees both individual freedom of choice and organizational flexibility, and fosters experimentation, which facilitates finding the most effective means for realizing efficiency gains from the use of firms. Pluralism is thus self-consciously pragmatic.

Unlike corporatism or participationism, pluralism therefore does not mandate a correspondence between firm organization and ideal. The state's posture towards corporations is to be an enabling one: The legal system enforces the voluntary contractual arrangements entered into by firm participants, and reduces transaction costs by codifying standardized terms of association. The need to protect the ability of individuals to shape their contracts freely necessitates government enforcement of property rights, as well as facilitation of unrestricted firm entry and exit. An exception to pluralism's openended approach to corporate forms is government regulation that prevents unacceptable negative externalities. ${ }^{74}$ Stated most succinctly, from the pluralist perspective, firm participants can agree to structure their organization as they wish. The dilemma for pluralism is that some individuals may desire to dictate the choice of others, and hence the most highly contested political terrain involves the sticky task of distinguishing restrictions on firms for bona fide externalities from those advocated out of paternalistic predilections or personal whim.

Finally, little can be said about the corporate structure necessary

74. In a pluralist framework, redistribution is generally thought to be best achieved by taxation and not by the use of legal rules, such as regulating corporate forms. In theory, with costless redistribution through lump sum taxes, efficiency and equity need not be traded off and can be separated. In practice, the contractual relationships of the parties to the corporation may undermine the success of legislated redistribution, and the redistribution obtained even by a costly tax and transfer system can be more precisely directed to needy individuals. See generally A.M. POLINSKY, AN INTRODUCTION TO LAW AND ECONOMICs 7-10, 105-13 (1983). More important, the theoretical economics literature that suggests that efficiency and equity cannot be separated has often been misunderstood by legal scholars. The import of this literature is not that courts and regulation are necessary for achieving equitable ends but that laxes of a non-lump sum nature, such as differential taxes on commodities, can be used to redistribute income. See, e.g., Mirrlees, Optimal Tax Theon: A Synthesis, 6 J. Pub. ECon. 327 (1976). 
for sustaining atomic individualism because hierarchical organizations do not have a place in this ideal. At best, forms minimizing the scale or scope of hierarchy would be the ones most congruent with the implementation of this vision.

II.

This section focuses on the most direct means of corporate law reform, proposals that seek to mandate formal relationships within firms. It reviews three of the more prominent areas of internal reform-altering the membership of the board of directors, modifying the information and control mechanisms available to the board, and restricting the board's activities during takeovers-and connects the proposals to the typology.

\section{A. Modification of Board Composition}

The continuing interest in board reform is, in part, a reaction to the Berle and Means research agenda. Their detailed reporting of the separation of ownership and control directs attention to what is acknowledged to be the decisive problem for corporate law: the structuring of incentives in hierarchical organizations. Although Berle forged a link between his positive account and his distinct normative vision-the separation of ownership and control signaled both the need and possibility for redefining property rights in the context of an emerging public-spirited managerial class-many contemporary scholars disregard that connection and consider the separation as the source of what they perceive to be the corporation's lack of a moral center. As a result, the optimistic aspect of Berle's vision has been jettisoned, and the board of directors, located institutionally in the interstices between ownership and management, becomes the mechanism for reasserting control over seemingly unaccountable corporations. Thus, relying on the Berle and Means separation thesis and often skeptical of the efficacy of market constraints, many advocates of change seek to redirect the corporation's activities by altering the composition of the controlling group, the board. Some scholars see the separation as a problem to be overcome by using the board as a vehicle to realign the interests of managers with those of shareholders, while others view it as an opportunity to enable nonstockholder interests to exert influence on corporations through the board. The public choice literature offers some support for such strategies: Con- 
trol of an organization's agenda can determine outcomes ${ }^{75}$ and corporation law assigns that power to the board. However, the interaction between the complex organization of a large corporation and its location in a series of markets, constraints undoubtedly affecting board decisions, considerably complicates any simplified public choice analysis.

This diversity in reaction to the separation of ownership and control, corresponds to three different formulations of board membership reform. The first seeks to strengthen the board's responsiveness to shareholder interests, an aim generally thought to be accomplished by the use of independent directors. The second proposes establishing a constituency-based board composed of directors who represent specific interest groups other than shareholders, and the third advocates the use of public interest directors. To underscore what is perhaps self-evident, retaining the board of directors, regardless of its composition, maintains and reinforces the hierarchical organization of the corporation. Programs to change the board's composition can accordingly be characterized by their correspondence to corporatism or pluralism. The important distinguishing factors are the interests the directors represent and the model of the board's decisionmaking process. In order to place the proposals in context, the relationship between state corporation codes, finance theory, and the typology will be sketched first.

The board in the statutory setting. From the perspective of corporation law, the board of directors, which sits at the top of the corporate hierarchy, commands and directs the firm's activities. ${ }^{76}$ Boards are generally composed of two types of directors, inside directors, who serve concurrently as full-time officers or employees of the corporation, and outside directors, who possess varying degrees of financial independence from the enterprise. Although the statutory scheme requires that directors be elected by shareholders, because of the number and geographic dispersion of shareholders and their individually small stakes in most large corporations, it is accepted wisdom that management selects the board. In addition, directors rely heav-

75. See D. Mueller, Public Choice (1979); Levine \& Plott, Agenda Infuence and Its Implications, 63 VA. L. REv. 561 (1977). Correspondingly, if managers control the board's agenda, focusing solely upon the board's composition would not be particularly useful.

76. Relatively recent amendments to several state codes permit the board to perform a less active, supervisory role. E.g., A.L.I.-A.B.A. MODEl Corporation Acts Practice HANDBOOK: MODEL BuSINESS CORPORATION ACT 142 (1974) (comments on amendments to section 35); DEL. CODE ANN. tit. 8, § 141(a) (1975). 
ily upon the inside officers for information concerning the corporation's affairs. These institutional features provide ammunition for critics who attack corporate boards as ineffective because they do not act independently of inside management. State law, however, handles the issue of director independence by a system of fiduciary obligation whose touchstone is the goal of promoting the interests of shareholders, which courts interpret as the maximization of firm profits. Legal liability is imposed, at least in theory, on directors for failing to fulfill their duties unless the shareholders unanimously consent to the breach, although a director's business judgment is not second-guessed by courts in the absence of an explicit conflicting personal interest in the transaction. ${ }^{77}$ Consequently, while the board has a well-defined role that places it at the top of the organization, that of furthering the interests of the owners, the ability of existing institutions to implement that goal, and not only the goal's desirability, is of concern to many corporate law reformers.

The board's role under state corporation law-to maximize the production gains from the central coordination of hierarchy for the benefit of the firm's owners-is grounded in pluralist values. The reasons for supporting profit maximization as the firm's objective, as well as the association of the statutory scheme with pluralism, can be most incisively explained by reference to a fundamental theorem in financial economics, the Fisher Separation Theorem. It states that under conditions of perfect capital markets, production or investment decisions can be separated from consumption decisions. ${ }^{78}$ This means that the owner of a firm can delegate the production (investment) decision to managers. Because in perfect capital markets a shareholder can adjust for his preferences for consumption over time by borrowing or lending against his wealth (the value of his shares), which increases directly as the firm's value increases, managers need only follow the decision rule of choosing the production plan that maximizes the firm's market value and each owner is made as welloff as possible. Shareholders can therefore give their manager-agents

77. See generally W. Cary \& M. Eisengerg, Cases and Materials ON Corporations 518-712 (5th ed. 1980).

78. The relation between consumption and investment or saving is an intertemporal problem: You can choose to consume now or to consume later. The Fisher Separation Theorem states that the investment or production decision does not depend on the individual's time preference, that is, on how much he prefers to consume today instead of tomorrow. Rather, it depends on the relation between the technically feasible set of combinations of goods and the market rate of exchange, which is the aggregate market trade-off between consumption now and later. For a lucid exposition, see J. HirshleIfER, PRICE THEORY AND APPLICATIONS 497-98 (2d ed. 1980). 
a decision rule that does not require the discovery and reconciliation of the personal time preferences (consumption decisions) of multiple principals.

The theorem accordingly implies that profit maximizing, or more precisely, maximizing equity share prices, ${ }^{79}$ has some very powerful properties: It is a statement of shareholder unanimity. Despite the ostensible difficulty for decisionmaking created by the prospect of numerous principals with diverse preferences, because managers can be given a simple and straightforward decision rule with which all owners would agree-maximize profits - the firm is an extraordinarily efficient device. At the same time, each owner-principal's freedom of choice is preserved, while his personal welfare is maximized, since no one shareholder's consumption pattern is constrained by the preferences of the others. Legal rules giving power to the board to act in the shareholders' interests to maximize profits, when viewed in light of the learning of the Fisher Separation Theorem, promote the core elements of a pluralist polity, the realization of individual ends by means of organizations.

There is, however, ambiguity concerning the unanimity of shareholder desires, and hence the optimality of a profit maximizing decision rule for managers, when the strong assumptions of the Fisher Separation Theorem are relaxed. In incomplete or noncompetitive markets, the propriety of assuming shareholder unanimity on valuemaximization can be questioned. ${ }^{80}$ To understand this caveat, uncertainty must be introduced into the analysis. This can be done by viewing the future probabilistically, as an array of possible states of the world, each of which has a specific likelihood of occurrence and payout. Uncertainty is then not knowing which state will actually occur. In such a world, a stock market can perform a crucial insurance function. To the investor, a security is a claim to a set of possible payoffs in the future that depend upon the state that occurs. ${ }^{81}$ If there is a complete set of markets, then there is a unique security for every possible future state. Individuals can thereupon insure them-

79. When uncertainty is modeled, the profit-maximizing objective for firms in equilibium in a certain world is replaced by the maximization of market value or equity share prices. For expository convenience, the text will use the terms interchangeably.

80. E.g., Radner, A Note on Unanimity of Slockholders' Preferences Among Altemative Production Plans: A Reformulation of the Ekem-Wilson Model, 5 BELL J. ECON. 181 (1974); S. Grossman \& J. Stiglitz, On Stockholder Unanimity in Making Production and Financial Decisions, Technical Report No. 224, IMSSS, Stanford University (Nov. 1976).

81. Actual stocks are composites of pure securities that pay off a specified amount if a particular state occurs, and nothing if any other state occurs. 
selves against the vagaries of the future and obtain whatever consumption pattern they desire, by trading and combining these statecontingent securities. Because there are securities that cover all possible events, uncertainty, in effect, can be eliminated, and the Fisher Separation Theorem continues to hold. ${ }^{82}$

Under the more realistic conditions of incomplete markets, however, maximizing the firm's market value may not be the desired choice of all shareholders. In an incomplete market, by definition, individuals cannot purchase a state-contingent claim for every possible state of the world. They are therefore unable to adjust for their consumption preferences under all possible states by trading securities, and unanimity will consequently not be achieved. ${ }^{83}$ Instead, each shareholder will favor a production plan that attains his preferred state, which may be neither the value-maximizing plan nor the choice of any other investor.

But if strict conditions of competitiveness are met, then the incompleteness of the stock market does not negate the unanimous choice of value maximization and it can, in fact, be ignored. ${ }^{84}$ In a noncompetitive capital market, firms could affect the aggregate supply of securities, and thereby alter future states, by changing their capital structures. As a result, investors would not be able to adjust for their preferences over different states by trading securities and

82. The technical explanation is that because investors can trade, everyone's marginal rates of substitution for consumption across states will be equated with relative stock prices in equilibrium. This is basically the Arrow-Debreu contingent commodities model of general equilibrium. Firms can affect shareholder utility only by affecting their wealth through changes in current share prices because the state space is fully spanned by existing securities. See generally T. COPELAND \& J.F. Weston, Financial TheORy and Corporate Policy 108-27 (2d ed. 1983). The number of securities may be considerably less than the number of states when trading takes place over time, depending upon the way uncertainty is resolved. Kreps, Multiperiod Securities and the Efficient Allocation of Risk: A Comment on the Black-Scholes Option Pricing Model, in The Economics of InFormation AND UnCertainTy 203 (J. McCall ed. 1982).

83. When markets are incomplete, the optimality condition equating investor marginal rates of substitution across states and stock prices cannot be fulfilled. The basis of the work on shareholder unanimity is the important paper by Diamond, The Role of a Slock Market in a General Equilibrium Model with Technological Uncertainty, 57 AM. ECON. REv. 759 (1967), which extends the Arrow-Debreu model to include the stock market.

84. Makowski, Competition and Unanimity Revisited, 73 AM. ECON. REv, 329 (1983); Makowski, Competitive Stock Markets, 50 Rev. ECon. STud. 305 (1983). In effect, it is price taking behavior and not spanning that is crucial for unanimity. Positive profits can coincide with competitiveness; only the perfect elasticity of demand for stock is needed. Makowski, Competitive Stock Markets, supra. These results also depend on the absence of short selling. If short sales can occur, then spanning, that is, market completeness, is required for attaining shareholder unanimity on value maximization. Makowski, Competition and Unanimity Revisited, supra, at 336-37. 
unanimity would not be attained. ${ }^{85}$ In short, "true" competitivity, an elusive term whose meaning varies with the user, ${ }^{86}$ is the pivotal condition for unanimity.

The introduction of more realistic assumptions suggests that specification of a firm objective can become problematic, ${ }^{87}$ for without shareholder unanimity to yield a clear decision rule, analysis would be virtually intractable. In this regard, it is intriguing that even without the insights of the economic apparatus legal rules tend to mirror the perspective of the finance ideal of shareholder unanimity, adopting the goal of profit maximization. No doubt, the appeal of profit maximization to courts and legislators, as well as financial economists, is in large part due to a reality constraint: It is not simply the best, but it is the only operational decision rule that we currently have.

The focus of many of the reforms examined in the succeeding discussion, however, is an altogether different source of complexity in the model. Given its assumptions about markets, the Fisher Separation Theorem does not require answering the important behavioral question whether directors and managers will indeed follow the value-maximizing decision rule. Yet, for example, if the risk preferences of managers are not congruent with those of shareholders, then managers will not undertake investment projects the shareholders would accept. ${ }^{88}$ A related and even more important concern, created by the informational asymmetry in the shareholder-manager relationship, is the moral hazard problem. Shareholders cannot directly observe, or observe at low cost, the activities of their agents managing the firm. But the agents' actions, such as how hard they work or whether they recommend good projects, affect how well the business does. In this sense, the Berle and Means empirical finding of the separation of ownership and control draws attention to the master corporate law issue for all pluralists, the problem of principal-agent

85. Nielsen, The Firm as an Intermediary Between Consumers and Production Functions Under Uncertainty (1974) (Doctoral Dissertation, Stanford University).

86. Many of the results concerning shareholder unanimity or the lack thereof are derived from models of competition that are not "truly" competitive. Makowski, Competitive Stock Markets, supra note 84, at 306; Nielsen, supra note 85, at 168, 195-96, 208-11.

87. See Baron, Investment Policy, Optimality, and the Mean-Variance Model, 34 J. Fin. 207 (1979).

88. The economic literature has modeled the problem of incongruous risk preferences in several different ways. See, e.g., Holmstrom, Managerial Incentive Problems-A Dynamic Perspeclive, in EsSAys In ECONOMICS AND MANAGEMENT IN HONOUR OF LARS WAHLBECK 209 (1982); Ross, The Economic Theory of Agency: The Principal's Problem, 63 Am. Econ. REv. 134 (1973). 
incentive compatibility, how best to ensure that individuals creating firms obtain the efficiency gains from hierarchies. While economists seek to identify employment contracts that provide incentives to encourage managers to act in the shareholders' interests, the usual approach of legal scholars concerned with the same problem has been to suggest modifications in institutional form, centered upon the board. $^{89}$

\section{A pluralist approach to board composition: Representation of shareholder} interests. One of the most prominent proposals for board reform puts independent directors on the board. Although the term is imprecise, an independent director typically connotes an individual not employed by, or otherwise financially interested in, the corporation's business. The concept is primarily concerned with limiting the board's susceptibility to management influence and accordingly, the precise obligations of independent directors vary with each proposal. Placing independent directors on boards is, however, commonly thought to mitigate the agency problem identified by Berle and Means, and hence it is interpretable as an effort to refine pluralist arrangements. By using internal monitors to reassert shareholder control over managers, the independent board is a means to resolve the accountability dilemma.

The link between independent director reform and pluralism can best be illustrated by examining in some detail Melvin Eisenberg's The Structure of the Corporation, ${ }^{90}$ the most trenchant and comprehensive statement of the position that seeks increased management accountability to shareholders. In addition, the American Law Institute's (ALI) controversial tentative draft on corporate governance substantially tracks his proposals for board reform. ${ }^{91}$ Eisenberg

89. Cf. Rogerson, Repeated Moral Hazard, - EcoNOMETRICA — (1984) (forthcoming) with the articles discussed at notes $90-156$ infra and accompanying text. Some legal commentators reject reform efforts and endorse the approach of the statutory regimes (reliance on the common law of fiduciary duty) as the only necessary legal supplement to market constraints on managers. See, e.g., Easterbrook \& Fischel, Corporale Control Transactions, 91 YaLE L.J. 698 (1982).

90. M. Eisenberg, The Structure of the Corporation: A legal Analysis (1976).

91. American Law Institute, Principles of Corporate Governance and STRUCTURE: Restatement AND ReCOMmendation (Tent. Draft No. 1, 1982) [hereinafter cited as ALI DRAFT]. Eisenberg is the reporter for the section on board structure. In light of heated controversy over the proposals, in a more recent draft many of the mandatory provisions on board structure were changed to voluntary recommendations. AMERICAN LAW INstitute, Principles of Corporate Governance: Analysis and Recommendations (Tent. Draft No. 2 1984) [hereinafter cited as ALI REv. DRAFT]. 
develops a model of the corporation, based on the two organizing themes of pluralism, individualism and delegation, that allocates decisional responsibilities between shareholders and managers. In his view, individuals use the corporate form, giving managers autonomous decisional authority for ordinary business matters, in order to achieve an optimal allocation of resources. ${ }^{92} \mathrm{~A}$ corporation is an efficient device for furthering the interests of its owners.

Eisenberg maintains that for public corporations, unlike closelyheld firms, decision rules must be mandated by statute because bargaining between owners and managers is not feasible, given the large numbers and geographical dispersion of shareholders. ${ }^{93}$ He expressly rejects Berle's benevolent managerialism and insists that shareholders should have voting rights in the context of decisions involving a substantial change in the structure of the enterprise or relating to the firm's control apparatus, because managers will act in their self-interest, contrary to the shareholders' or the public interest. ${ }^{94} \mathrm{He}$ supports this active role for shareholders by developing the thesis, countering Berle and Means' findings, that in most corporations there are shareholders with holdings large enough so as to possess strong proprietary interests that provide them with the incentive to exercise control over structural decisions. ${ }^{95}$

Concern over the need to constrain managers and recognition of the demands of large organizations lead Eisenberg to discard the conventional model of the board managing the corporation as infeasible and inefficient for public corporations. He advocates instead a monitoring board to check management's performance. ${ }^{96}$ To implement his model of the board, Eisenberg requires a majority of the directors to be independent. The premise is that placing a significant number of independent directors on the board will weaken, if not eliminate, the incentives for directors to please incumbent managers rather than to question and evaluate carefully management's performance. By this means, Eisenberg seeks to fortify or shore up the pluralist model, which sets as the board's objective the protection of

92. M. EISENBERG, supra note 90 , at $68,318-19$.

93. Id. at $37-45$.

94. Id. at $25-34$.

95. Id. at $42-68$.

96. Id. at 162-68. As a diffuse, shifting group, shareholders cannot monitor management effectively. There is little financial incentive to do so given the shareholder's small share in the gains from such individually costly activity. A board can overcome this free rider problem because the costs, as well as the benefits it produces, are spread proportionately among all the owners. 
shareholder interests but in practice, he believes, fails to achieve its goal because institutional arrangements have shifted power away from shareholders and corporate boards towards inside managers. By policing management, Eisenberg's independent board is an institutional device for reducing the agency costs created by the separation of ownership and control.

The troubling aspect of Eisenberg's model is its failure to delineate the mechanism guaranteeing incentive compatibility between independent directors and shareholders. His analysis does not provide a basis for the optimistic claim that independent directors will act in the shareholders' interests when managers and other directors have failed to do so. Without question, Eisenberg has identified an important agency problem, but his solution only shifts it from one arena, shareholder relations with inside managers, to another, those with the board. An interesting lacuna in the board reform debates is that Eisenberg's more vehement critics do not dwell on this crucial difficulty ${ }^{97}$ Instead, they deemphasize the severity of the agency quagmire at the heart of his reform proposal, and contend that altering the board is unnecessary because of the corporation's nesting in a series of markets. ${ }^{98}$ In brief, they challenge the import of Berle and Means' separation thesis by attributing to markets the creation of incentives sufficient to prod managers to act in the shareholders' interest. Eisenberg's critics thus deny or assume away the agency problem.

For instance, a prominent critic of much of corporate law reform, John Hetherington, uses the theme that the stock market reduces the significance of the separation of ownership and control ${ }^{99}$ as the linchpin for rejecting the establishment of independent monitoring boards. Hetherington maintains that independent director proposals increase the cost of managing by adding time to the decision-making

97. A few commentators have noted this gap in the position. See Brudney, The Independent Director- Heavenly City or Polemkin Village, 95 HARv. L. Rev. 597, 633-39 (1982); Levmore, Monitors and Freeriders in Commercial and Corporate Settings, 92 YALE L.J. 49, 61-63 (1982). In addition, the more telling point is that if incentive-compatible employment contracts can be written to solve the agency problem between shareholders and independent directors, why cannot similar contracts be written for top managers, eliminating the need for a separate board?

98. E.g., R. HEssen, supra note 29, at 81; Hetherington, When the Sleeper Wakes: Reflections on Corporate Govemance and Shareholder Rights, 8 HOFSTRA L. REv. 183 (1979).

99. Hetherington, supra note 98, at 186-87. For other critiques along these lines, see $R$. Winter, Government and the CoRporation (1978); Fischel, The Corporale Governance Movement, 35 VAND. L. Rev. 1259 (1982); Werner, Management, Stock Market and Corporate Reform: Berle and Means Reconsidered, 77 Colum. L. REv. 388 (1977). 
process and by diminishing "management aggressiveness, creativity, and flexibility."100 In his view, because compatibility of shareholder and manager interests is already ensured by the efficient operation of the stock market, such additional costs cannot be justified by the alleged benefits of the reform's alignment of interests. The argument is founded on the proposition that if managers act adversely to shareholder preferences, stock values will decline, making the firm the likely object of a takeover bid through which incumbent managers are replaced. The threat of loss of employment is deemed sufficient to deter managers from deviating from shareholder wishes. ${ }^{101}$

The introduction of inefficiencies into corporate operations is not Hetherington's only objection to changing the composition of the board. He also emphasizes that it will limit investor choice. ${ }^{102} \mathrm{His}$ evaluative benchmark for reform proposals, the ability of corporate organizations to enhance individual welfare, is derived from the corporation's capacity to mesh the preferences of shareholders with a command system of control. A legal regime prescribing internal firm arrangements, such as specifying who can sit on the board, is considered undesirable because it impinges without good cause on shareholder choice.

Notwithstanding their clash over the merits of placing independent directors on the board, both Hetherington and Eisenberg share a pluralist view of the corporation, that emphasizes efficiency and affirms the board's role as the representative of shareholder interests. The differences between Eisenberg and Hetherington may be attributable to the division among pluralists that turns on their attitude towards the need for government. In contrast to Eisenberg, Hetherington's views on other issues, such as his objection to much of the current and proposed federal regulation of corporations, ${ }^{103}$ evinces an opposition to expanding government activity characteristic of minimal state pluralists. The minimal state position seeks to limit government interference and would give little credence to the assumption of a market failure in the private contractual arrangements establishing a corporation, which is the pluralist rationale for a law prescribing who sits on the board.

100. Hetherington, supra note 98 , at 192.

101. The analysis was first suggested by Henry Manne, see Manne, supra note 3, and has been elaborated and extended by numerous writers. As with many good ideas, initially it was not well received. For a nice summation and synthesis, see Fischel, supra note 99, at 1263-64.

102. Hetherington, supra note 98 , at $192,196-97$.

103. Id at 222, 232-33, 252-54 (objecting to federal chartering and expansive activity of SEC, including going private and insider trading regulations). 
But a very important source of the disparity in Eisenberg's and Hetherington's positions is their opposing descriptions of the world. In addition to disagreeing with Eisenberg over the efficiency of the capital market and its disciplining force on managers, Hetherington presents a different story concerning the import of the separation thesis. Rather than adopt Eisenberg's approach of demonstrating that control matters to shareholders, Hetherington contends that Berle and Means' findings did not reveal a new trend of investor passivity, and that public shareholders never actively controlled their corporation's affairs. ${ }^{104}$ Consequently, he dismisses calls to strengthen shareholder control as unnecessary and unwanted. He views exit by selling shares in the market an altogether adequate mechanism for the realization of shareholder ends. The stark divergence in policy recommendations of protagonists who have the same objective is possible because of our limited knowledge concerning the impact of different types of boards on firm returns. If careful studies testing the effect of board composition upon shareholder wealth were available, Eisenberg and Hetherington could amicably resolve their dispute. Still, because of the limitations of available statistical techniques for analyzing the impact of events on share prices, ${ }^{105}$ when confronted with empirical studies, a scholar's priors, such as his beliefs concerning the efficiency of markets or the efficacy of legislated solutions, will undoubtedly influence the weight or conclusiveness he accords such research.

An empirical challenge to the value of independent directors has also fueled the controversy over the extension of Eisenberg's model in the ALI corporate governance draft. Critics of the draft maintain that because there is little empirical evidence that boards with a majority of independent directors increase investor returns, board composition should not be mandated. ${ }^{106}$ But from a pluralist perspective, the decision rule that the draft sets out for managers is

104. Id. at 194.

105. For example, statistical significance tests fail to pick up abnormal returns of one percent or less, and are very sensitive to the accuracy of the event date. See Brown \& Warner, Measuring Security Price Performance, 8 J. Fin. ECON. 205, 215-17, 225-27 (1980).

106. See MacAvoy, Cantor, Dana \& Peck, ALI Proposals for Increased Control of the Corporation by the Board of Directors: An Economic Analysis, in STATEMENT OF THE BUSINESS RoundTABLE ON THE AMERICAN LAW INSTITUTE's PROPOSED "Principles OF Corporate GOVERNANCE AND STRUCTURE: RESTATEMENT AND RECOMMENDATIONS" (1983) [hereinafter cited as STATEMENT of THE Business Roundtable]; Scott, Corporation Law and the American Law Institute Corporate Govemance Project, 35 STAN. L. REv. 927, 932-35 (1983). The revised draft recommends, rather than requires, the presence of independent directors. See note 91 supra. 
more troubling than the debate sparked by the proposed independent board, which is, after all, in principle an empirically resolvable dispute. The draft diverges from Eisenberg's earlier formulation by adding a qualification to profit maximization that permits managers to follow generally accepted principles of business ethics, as well as to make reasonable philanthropic expenditures. ${ }^{107}$ The inclusion of a manager's ethics in a standard for decisionmaking undercuts the draft's pluralist focus, the alignment of manager incentives with shareholder ends, for the effect is to render managers unaccountable to anyone. As the draft illustrates, given the same set of facts, completely contradictory management decisions are permissible and immunized from shareholder attack, with the outcome depending solely on which of the draft's criteria, profit maximization or business ethics, the manager chooses to invoke. ${ }^{108}$

It is puzzling that the draft would require a decision rule that provides no guidance to management without marshalling evidence that shareholders in reality prefer managers to follow unspecified ethical codes rather than to maximize profits within the rule of law. This feature is especially disturbing because profit maximization is the only goal for which we can at least theoretically posit shareholder unanimity. Short of such evidence, the approach more consistent with pluralism, if corporate goals are to be altered, is an enabling one. Ethical codes should be treated like any other provision in a corporation's charter-the presumption of profit maximization could be changed by express shareholder approval. ${ }^{109}$ This policy would have shareholders directly authorize when their agents are to deviate from profit maximization, rather than leave the decision to manage-

107. ALI DRAFT, supra note $91, \S 2.01$. This is unchanged in the revised draft. The third exception for complying with the law is unproblematic and, indeed, unnecessary, as it is a definitional constraint on profit maximization. Pluralism supports regulating corporations when there are externalities, in order to affect the profit maximization calculus. See note 74 supra and accompanying text and note 122 infra and accompanying text. While a great amount of energy of the draft's critics was expended on a minor issue, whether it was restating doctrine, see, e.g., STATEMENT OF THE Business RoundTABle, supra note 106, at C2-C3, C8, some participants did voice concerns similar to those discussed in the text, see, e.g., AMERICAN LAw Institute, Proceedings 1982, at 426-27 (1983) (Oliver E. Williamson) [hereinafter cited as ALI Proceedings]; id. at 429-31 (David S. Ruder).

108. ALI DRAFT, supra note 91, at 30, 33-34 (Illustrations 11, 12, 14, and 15); ALI REv. DRAFT, supro note 91 , at 38,42 (same).

109. Indeed, the revised draft states that shareholders may adopt special purpose charter provisions that reject profit maximization as the corporate goal. ALI REV. DRAFT, supra note 91 , at 27 . It is inexplicable why the drafters require such an approach for altering the profit maximizing objective yet do not recognize that the ethical judgment exception entails an analogous situation. 
rial discretion. Further, it would avoid the quandary of enacting a decision rule for managers that violates shareholder unanimity. For under an enabling approach, investors with similar ethical preferences could separate themselves by firms. The draft's prescription, by contrast, invites experimentation with a Berlian approach of entrusting business associations to a benevolent and enlightened managerial elite, which is inconsistent with its support for independent directors. ${ }^{110}$

For the most part, the debate over independent directors has been waged by pluralists, and this is what makes the ALI draft's statement of objectives confusing. However, some criticisms of Eisenberg's proposals originate from totally different normative perspectives. For instance, Lewis Solomon has asserted that Eisenberg's reforms will have little effect on corporate governance because Berle and Means demonstrated that management, and neither the board nor the shareholders, controls the corporation. ${ }^{111} \mathrm{He}$ offers instead a program of decentralization. His plan would transform what he terms the "consumer-oriented" preferences of individuals in a market economy into "subsistence level" desires, in order to reduce industry and community size, while implementing the worker self-management and codetermination board models. ${ }^{112}$ All of these proposals, except the codetermination board, for which he expresses ambivalent support, promote a participationist ideal. ${ }^{13}$

Solomon is not engaged in a pluralist's critique: $\mathrm{He}$ is fundamentally hostile to the delegated control system of corporations. He envisions a decentralized society with diminished production requirements that can be met by small-scale organizations in which

110. The drafters' confused perception of the corporation appears in several places in the revised draft. For instance, the draft asserts that the standard of corporate conduct "speaks only of the corporation" and does not impose "obligations . . . . on corporate officials," ALI REV. DRAFT, supra note 91, at 26, without telling us who or what the operating corporation is if it is not the managing agents. The revised draft also describes the corporation as a "social institution" whose economic goals must be constrained by "social imperatives and . . . needs." Id. at 28.

111. Solomon, Restructuring The Corporate Board of Directors: Fond Hope-Faint Promise?, 76 Mich. L. REV. 581, 610 (1978).

112. Solomon, Toward a Federal Poligy on Work: Restructuring the Governance of Corporations, 43 GEO. WASH. L. REV. 1263, 1341-42 (1975). The worker self-management and codetermination board models are discussed at notes 125-135 infra and accompanying text.

113. See notes 125-128 infra and accompanying text. Solomon is not an ardent supporter of codetermination because it retains the "traditional authoritarian organizational model" and has not been a vehicle for active worker participation. Solomon, supra note 112, at 1318-20. This statement further supports viewing Solomon as favoring decentralization and the participationist ideal. 
workers actively participate. ${ }^{114}$ Furthermore, he does not perceive the issue of corporate accountability as a problem involving production externalities, as would a pluralist. Rather, in a frontal attack on the use of hierarchy, Solomon defines the problem as the allocation of power and decisionmaking among the corporation's members. ${ }^{15}$ In addition, his proposal seeks to undermine the expertise developed in the specialization of tasks, which is central to hierarchical organizations. The decisionmaking unit is to be a small group of citizens, which increases the role of nonexperts, for Solomon believes that in such a setting each member of the group can be more informed and therefore will be better able to participate fully in decisions. ${ }^{116} \mathrm{His}$ rejection of the board's composition as the focal point of reform and his emphasis on the need for participation at all levels of the firm suggest a strong antipathy to hierarchical organization and a preference for a pattern of relationships congruent with the participationist ideal. ${ }^{117}$ And it is this vision that motivates his opposition to Eisenberg's program for reform.

The corporatist approach: An expansive view of the board's constituency. A great number of board composition proposals and, in particular, those most frequently associated with corporate law reform, have much in common with corporatism. The two major variants of these reforms are public director proposals and client-group or constituency-based models of the board. The coupling of an expansion of the interests to be represented by the board with an organic conception of how the board is to fulfill its responsibilities gives these proposals a corporatist cast. The constituency board model relies on special interest directors to widen the influence exerted upon management beyond the perspective of shareholders. The new interests to be

114. Solomon, supra note 112 , at 1340-42, 1329-31.

115. Id. at $1306,1335-37$.

116. Id. at 1341 .

117. Solomon's reliance on government-funded research to direct society to his ideal and his qualified support of state ownership of productive activity have corporatist overtones, id. at $1333,1336,1342$, but the clearly predominant theme is decentralization. One could perhaps view Solomon as sympathetic to atomic individualism, given his desire to chop up corporations into smaller entities. In addition, his goal of the "realization of human values," which recurs in the participatory democracy literature, can presumably be achieved on either an individual or group basis. However, the conclusion that the institutional arrangements he advocates are most congruent with an organic decentralized vision, is sustained by the absence in his work of both individualist notions of interest and concern for flexibility in individual contracting arrangements, in conjunction with an implicit rejection of market solutions and an emphasis on the value of participation and group decisionmaking in all realms of social activity. 
represented can include employees, suppliers, customers, consumers, and neighboring communities, but the most widely discussed board reform adds only worker representatives. As would be expected, the public director proposals advocate representation on the board of a less easily identifiable public interest. Like independent director reforms, the special and public interest director approaches are premised upon delegated decisionmaking. They take the board as the locus of authority and expect to change firm activity by altering who is in control and not how control is exercised.

Either of two distinct models of corporate governance can drive the special interest director approach to reform. ${ }^{18}$ In one model, although the board is composed of directors representing different interest groups, it operates as a smoothly functioning whole whose objective is coordinated by omniscient directors. This model, emphasizing the firm's organic cohesiveness and harmony, is akin to corporatism. When making a decision, directors subordinate the interests of their clientele to a vaguely defined overriding interest of the enterprise.

The other model is an adversary-type board that replicates a legislature. Diverse interest groups with conflicting desires confront each other on the board and form coalitions to further their ends. This view of the board has a pluralist theme: Representatives of competing constituencies vie for control and champion the interests of their members. In point of fact, the proposal has more in common with corporatism than pluralism. Several decisive differences make the analogy to pluralist legislatures inappropriate. Representation in the board room of constituencies other than shareholders reflects the expansive conception of politics of organic theories: It shrinks, if not obliterates, the pluralist separation of private and public realms of action. In addition, the pluralist concern with enforcement of property rights is ignored by the extension of electoral politics, mirroring Berle's position that corporate ownership includes constituencies other than shareholders. Most important, the productive efficiency of corporate organization is diminished by the tradeoffs in firm goals that are introduced once the board no longer seeks to further the homogeneous preferences of shareholders. Hence, the model's pluralist origins are far more apparent than real. In any event, the more

118. Cf. Brudney, supra note 97 , at 600 n.5 (uncertain if purpose of special interest directors is to achieve consensus or to polarize the board); Solomon, supra note 111, at 587 (two models of board: adversary of management or monitor and advisor cooperating with management). 
prominent special interest director proposals are closer in spirit to the cohesive than the adversary board model. As a result, corporatist features tend to predominate distinctly in the special interest director proposals.

The public director genre evinces even less conceptual ambivalence. The notion of directors imbued with a public interest is intimately related to an organic perspective. It implies the existence of an objectively knowable interest that is distinct from, and at odds with, the interests of the enterprise's owners.

1. Public directors. A recent effort to resuscitate the Berlian public-spirited manager is Elliot Weiss' proposal to create a class of national directors who are to occupy two-thirds of the board seats of large corporations. ${ }^{19}$ Chosen by shareholders from a candidate pool designated by the federal government, these directors are to follow a newly legislated ethic of responsibility, termed "altruistic capitalism." 120 Weiss believes that changing the values of the directors at the top of the organization can redirect firm activities towards more socially responsible behavior, and that other techniques cannot as easily implement such a goal. ${ }^{121} \mathrm{He}$ therefore not only retains the command structure, but seeks to strengthen it, using the organizational benefits of hierarchy to incorporate societal concerns into the decisional process of firms.

To the extent that Weiss' code is concerned with refining the corporation's profit maximizing calculus to include the social costs of production externalities, his proposal can be considered a pluralist reform. As has been mentioned, pluralism most often seeks a role for government when external diseconomies or economies prevent markets from functioning. Public directors could provide a more cost effective mechanism than government regulation for correcting market failures if the board acquired the pertinent information more cheaply than an outside agency. ${ }^{122}$ But Weiss' code of conduct in-

119. Weiss, Social Regulation of Business Activity: Reforming the Corporale Governance System to Resolve an Instilutional Impasse, 28 U.C.L.A. L. REV. 343 (1981).

120. Id. at $345,427-29$. His standard is similar to that of the ALI draft. See note 107 supra and accompanying text.

121. Weiss, supra note 119 , at $413-18$ \& n.321.

122. This is essentially an empirical question. Cf. Brudney, supra note 97 , at $654-55$ (arguing government regulation is more cost effective than use of directors). Some forms of government intervention to resolve the problem of externalities are more compatible with pluralist ends than others. Approaches that focus on providing incentives to affect a particular individual or firm's decisions, such as the use of taxes or marketable rights, are more consonant with pluralism than less flexible techniques such as standard setting. Standards 
cludes more than the modest pluralist concern for internalizing the social costs of production. Other aspects of his guide to conduct, in conjunction with the mechanism of director selection, tend to support the conclusion that Weiss' suggestions promote a corporatist ideal. For instance, he requires directors to engage in information sharing with competitors, and would modify the antitrust laws to encourage this activity. ${ }^{123}$ Such a scheme closely resembles the segmented structure of industry associations that link business units in corporatist systems. Although some of the information to be shared concerns innovation, which has characteristics of a public good and thus can support a pluralist basis for government-imposed cooperation, enforced sharing would also foster increased industry concentration, undermining the competition among autonomous organizations that is essential for the viability of pluralism.

In addition, the idea of government-approved directors is a move towards corporatism. It introduces a base for state intervention into and coordination of business affairs, and thereby reduces the separation between public and private sectors that is central to pluralist democracy. More specifically, although shareholders still elect the board, their choice is severely restricted, as is the articulation of their interests. The public interest divined by the new directors under Weiss' altruistic rule is to transcend shareholder concerns, an idea that is characteristic of an organic concept of representation. Both of these patterns of state restrictions, limiting the selection of corporate managers and the expression of constituent interests, are associated with corporatism, where similar forms of organizational control are an integral part of the political and economic landscape. The private ordering of business relations is circumscribed, conflicting with the pluralist concern for the integrity of individual choice and for organizational autonomy and flexibility. On balance, then, Weiss' proposal has fairly strong corporatist features: It is an attempt to obtain Berle's public-spirited civil servant manager by statutory fiat. ${ }^{124}$

coerce individual decisions, tend to produce less efficient production outcomes, and treat corporations as undifferentiated, organic units. A pluralist would opt for standards only when the transaction costs of implementing a system of taxes are greater than the allocative inefficiencies the standard regime would produce, or when permitting individuals to adjust their acts to penalty levels would infringe too severely on others.

123. Weiss, supra note 119 , at $422-23$.

124. Another attempt to create managers of the Berlian mold is a proposal calling for the establishment of schools for corporate directors to develop and transmit a socially responsible moral code. Earle, Corporate Governance and the Outside Director-A Modest Proposal. 36 WASH. \& LEE L. REV. 787, 804-07 (1979). 
2. Special interest directors. The most common proposal for a constituency board extends representation only to workers, adopting the West German codetermination system. ${ }^{125}$ This approach is at heart corporatist. In the codetermination model, the hierarchical organization of the firm is retained and reinforced by a two-tier board. There is a supervisory board of worker- and shareholder-elected directors at the top, which selects a managing board below it consisting of full-time managers who make day-to-day operating decisions. Lines of authority in the workplace are therefore essentially left unchanged from current arrangements by this sort of board.

Codetermination seeks by its structuring of the board to implement cohesive and harmonious employer-employee relationships, which is a primary aim of corporatism. The joint representation of workers and employers on the supervisory board resembles the integrative role of the industry-wide associations joining employers and workers and linking business and state that are common in corporatist theories. ${ }^{126}$ More practically, the primary benefit of codetermination is said to be an absence or lessening of labor unrest, ${ }^{127}$ which fosters the social cohesion and stability emphasized by corporatism.

The representation of interests in the codetermination system is also in keeping with corporatism. It is usually asserted that the managing board is responsible to a broad set of social interests, and members of the supervisory board are expected to give priority to the interest of the collective enterprise, subordinating the interest of the group within the corporation that selected them. ${ }^{128}$ The goal of stability achieved by submerging individual interests into a unified corporate entity is, of course, at variance with pluralism, which considers competition among interest groups, workers and managers being no exception, to provide an important systemic safeguard for democratic politics. ${ }^{129}$

125. E.g., Schoenbaum \& Lieser, Reform of the Structure of the American Corporation: The "Two-Tier" Board Model, 62 KY. L.J. 91 (1973); see Blackburn, Worker Participation on Corporate Directorates: Is America Ready for Industrial Democracy?, 18 Hous. L. REv. 349 (1981).

126. For examples of this integrative phenomenon in pre-World War I Germany and pre-World War II Italy respectively, see R. BowEN, supra note 34, at 16-17; C. ScHMIDT, supra note 34 , at $62-67$.

127. Solomon, supra note 112, at 1320; Vagts, Reforming the "Modem" Corporation: Perspectives from the German, 80 HARV. L. REv. 23, 70 (1966).

128. Schoenbaum \& Lieser, supra note 125 , at $97-98,100$.

129. Some commentators implicitly recognize that codetermination implies a distinctly different political model from pluralism when they object to transplanting codetermination into the American context because of its incompatibility with existing institutions. For instance, codetermination would require labor unions to abandon their adversary stance to- 
The ideal that is promoted by codetermination is different from that of proposals for industrial democracy or worker self-management, despite a shared emphasis on the welfare of workers. The key distinction is the divergence in attitude towards delegation. Codetermination builds upon a hierarchical ordering within the corporation between managers and workers, whereas worker self-management rejects outright that institutional arrangement. Adherents of self-management insist upon decentralization, with active and equal worker participation in all firm decisions. ${ }^{130}$

In contrast to codetermination, the aspirations of worker selfmanagement proposals are participationist. In the first place, full participation of workers at all decisional levels in the workplace is a decentralized organizational objective. ${ }^{131}$ It is the cornerstone of participationist programs. Second, although the organizational perspective differs, self-management, like codetermination, has an organic and not an individualist understanding of community. While there are passing references in the literature that treat worker participation as a vehicle for self-improvement, developing "democratic personality" traits, ${ }^{132}$ greater self-confidence, and sense of personal well-being, ${ }^{133}$ the more prominent theme formulates the goal in terms of general benefits to society or the worker group or class, and not as the cultivation of personal skills. When self-improvement is discussed, it is not an end in itself, but rather, it is only a means to guarantee superior group decisions. In fact, proponents of "industrial democracy" assert that with self-management the corporation will be run "in the interests of all," in contrast to "interest group management," the outcome foreseen for board composition reforms. ${ }^{134}$ They also claim that unlike current arrangements, which

wards management, in order to avoid conflicts of interest when sitting on the board. Blackburn, supra note 125, at 363-66; Vagts, supra note 127, at 74-75.

130. See, e.g., R. DAHL, supra note 64; R. MASON, supra note 63; C. PATEMAN, supra note 67.

131. In Robert Dahl's analysis of the political consequences of different types of corporate reform, worker self-management supports more decentralization and less external government control than changes in board composition. R. DAHL, supra note 64 , at 139 . Gar Alperovitz likewise identifies the ideal of the Yugoslavian worker self-management system as decentralization. Alperovitz, supra note 68 , at 55 .

132. C. PATEMAN, supra note 67 , at 64 . The hypothesis that participation in workplace decisionmaking will increase participation in politics is not supported by much empirical research. See, e.g., Greenberg, supra note 13 (worker-owners of American plywood cooperatives do not express interest in or support for transferring their own work experience into a participatory industrial and political democracy).

133. R. DAHL, supra note 64 , at 132.

134. Id. Dahl points out, in making this contrast, that interest group director proposals 
concentrate power in individuals who own property, self-management involves the decentralization of economic power in a collective unit comprised of those who work in the firm. ${ }^{135}$ Worker participation proposals are accordingly the decentralized variant of the total conception of politics embedded in organic thought, part of the quest for implementing direct group decisionmaking in all spheres of activity.

Extending board representation to workers is often supported as the only feasible enlargement of the corporate franchise because worker representation poses little difficulty in allocating votes and, even more than shareholders, workers' livelihoods depend upon the firm's success. ${ }^{136}$ Yet the most widely publicized board composition reform is a far more expansive special interest director board proposed by Ralph Nader, Mark Green, and Joel Seligman. ${ }^{137}$ Nader's board reform constitutes only one component of a sweeping program to restructure corporate law, but it is pivotal. Although the prevailing perspective of the other special interest and public director reforms is decidedly corporatist, the political ideal of Nader's plan is more difficult to identify. I do think, however, that corporatist aspects predominate in it as well.

The Nader blueprint requires the board to be composed of fulltime professional independent directors. Unlike the independent directors in Eisenberg's proposal, each Nader director is assigned to represent a special interest in addition to general oversight responsibilities. These special interests include, among others, consumer protection, employee welfare, environmental protection, and community relations. ${ }^{138}$ Shareholders are to elect all of the directors in order to avoid what Nader considers the two main problems for board members who are directly elected by specialized constituencies: They may wind up as either special pleaders for their interest groups and disloyal to the whole, or isolated by the "private" (shareholder-elected) directors and excluded from decisionmaking. ${ }^{139}$

Nader's reform bundle, however, does not neatly further any particular normative position. For example, at times Nader seems to

are more fitting with the "American ethos and political culture" than self-management. Id. at 138 . He thus implicitly recognizes that different political visions inform the two models.

135. Alperovitz, supra note 68 , at 55-56.

136. Vagts, supra note 127.

137. R. NADER, supra note 3. For ease of exposition, the text refers to the proposal as Nader's.

138. Id. at 125 .

139. Id. 
adopt a pluralist perspective. He suggests procedures for altering the nomination and election process for directors to enable shareholders to be more active in selecting the board. But the increased participation does not consistently expand individual choice. The directors are not to follow exclusively the interests of the shareholder-electorate; instead, they are to ascertain objectively the interests of specified nonvoting constituencies. Correspondingly, the proposal's objective is not the alignment of manager incentives with shareholder desires, as in the pluralist approach. What initially appears to be an electoral process designed to promote pluralist ends produces results that are inconsistent with that aim, for individual interests are subsumed into amorphous collective concerns. Ultimately, the selection procedure has more in common with participationism. Corporations are to become highly politicized, and investor participation in firm decisionmaking is increased, not in order to enhance shareholder welfare, but to further ambiguous social goals.

The designation of seats on the board for specified interests could also be viewed as a pluralist device that forces the board to internalize the social costs of its decisions. In contrast to Weiss' proposal of a federally approved list of director nominees, Nader's shareholders' choice of candidates is unrestricted. Nader further uses the rhetoric of pluralism to justify broadening the range of individuals entitled to a voice in the corporation's affairs. He alludes to the constitutional separation of powers and analogizes his board reform to such a political design, in which specialized constituencies, by counterbalancing each other, secure the rights of all. ${ }^{140}$ Moreover, an individualist explanation of the proposal could be offered: The new arrangement could be a Kaldor-Hicks move whereby the gains to the previously unrepresented individuals could more than compensate the welfare losses of the shareholders. But there is not even a hint of such a justification in the book.

Despite these pluralist themes, it is difficult to reach any conclusion but that business associations in Nader's program are designed to function as cohesive units, under state supervision, as envisaged by corporatism. Although the state does not select the corporation's directors in Nader's plan, it would closely supervise corporate activities through extensive statutory requirements: Specification of the interests the directors must consider is but a small part of an elaborate regulatory scheme. ${ }^{141}$ In addition, the subordination of the directors'

140. Id. at 125-26.

141. In another part of his program, Nader advocates a stringent antitrust policy of 
special interests to those of the whole in the deliberative process $\mathrm{Na}$ der envisions is an organic approach, and the politicization of the corporation he endorses fuses the public and private realms that pluralism strives to separate. Furthermore, regulation of the internal arrangements of firms by the national government undercuts the pluralist demand for diverse and autonomous institutions, by imposing uniformity on firms and thereby bounding the scope of private institutional innovation. This corporatist interpretation of Nader's proposal is corroborated by what he considers to be the roots of his platform. He invokes the concession metaphor of the corporation to justify his plan, ${ }^{142}$ which, as I have earlier maintained, is the doctrinal analogue of organicism. He also explicitly identifies his program with Berle and the progressives' political agenda, asserting that he shares both Berle's perspective on large corporations as private governments and the progressives' active regulatory approach. ${ }^{143}$

Adding up the pieces, Nader's plan for the board is little more than a pastiche of ideas that are mutually inconsistent, with corporatism providing, at best, a latent unifying theme. The typology makes plain the normative incoherence of his disjointed vision, by identifying which proposals or parts of proposals fit with which ideals. Nader undoubtedly might seek to defend this jumbling of ends as a pragmatic effort to fashion a politically acceptable package. But such a rationalization is a thoroughly unsatisfactory response. A coherent evaluation and choice of means can only be undertaken in the context of specified ends. A policy that requires implementing provisions that are fundamentally at odds with one another fails to do just that.

\section{B. Modification of Internal Structure: Refining Information, Communication and Transmission Processes}

Academic interest in altering the board's composition began to wane by the late 1970's, as reformers turned their attention to other modes of internal restructuring. Adopting the perspective of organization theory, some scholars concluded that the institutional demands of complex organizations such as large corporations make it

deconcentration that will "atomize" corporations and prohibit mergers between large firms. Id. at 227-36. Such a proposal, much like Henry Simons' suggestion in the 1930's, seems to further an atomic individualist ideal. But the move to decentralize is limited to inter-firm relations and does not reach inside single firms. Nader's overall approach seeks to strengthen the board's powers in order to redirect firm policies to incorporate broad social concerns.

142. Id. at 1,62-63.

143. Id. at 17 (Berle) and 67-70 (progressives). 
difficult for directors, particularly outsiders, to exercise control over firm activities, despite the board's location at the pinnacle of authority. ${ }^{144}$ By identifying internal constraints that render reform focused solely on directors problematic, the learning of organization theory furnished a framework for rejecting board composition proposals as counterproductive and subtly shifted discussion to potentially more intrusive structural reforms.

Legal scholars gleaned from the organization theory literature that the path for making business decisions more accountable is to ensure that pertinent information moves to the top of the corporate hierarchy. Hence, the primary object of interest is the corporation's internal communication system. Organization theory was quite naturally adopted as the analytical apparatus of scholars who desired to change decisionmaking within corporations because until recently it was the only line of research to penetrate the black box view of the firm of neoclassical economics. ${ }^{145}$

Although fundamentally descriptive in its approach, organization theory does have limited normative implications. It finds the vertical stratification of function in hierarchy to be a beneficial, if not a necessary, state of affairs. While economists typically emphasize the design of individual incentives to ensure the optimal operation of firms, organization theorists translate the need for incentives into the establishment of organizational routines, roles, and structures. There are two distinct schools of thought in the organization theory literature that suggest different normative visions, based on their analysis of

144. E.g., Coffee, Beyond the Shut-Eyed Senty: Toward A Theoretical View of Corporate Misconduct and an Effective Legal Response, 63 VA. L. REv. 1099, 1143-45, 1155 (1977) (rejecting Nader's special interest directors, Eisenberg's independent monitoring board, codetermination board, and public director proposal of Christopher Stone); Haft, Business Decisions By the New Board: Behavioral Seience and Corporate Law, 80 MicH. L. REv. 1 (1981) (rejecting Eisenberg's monitoring model).

145. An alternative avenue for analysis to aid in penetrating the firm that has yet to be explored in corporate law and that I believe will prove more promising than organization theory is the burgeoning work in information economics on contracting, which builds on the important work of Oliver Williamson, supra note 9, and, in particular, the research on incentives and optimal risk sharing. This research provides an elegant and sophisticated, though still incomplete, formal model of the firm. E.g., Rogerson, The Structure of Wage Contracts in Repeated Agency Models, _ RAND J. ECON. _ (1984) (forthcoming) (modeling contracts where penalty is termination of employment). For an application to a legal context, see Kornhauser, An Economic Analysis of the Choice Between Enterprise and Personal Liability for Accidents, 70 CALIF. L. REv. 1345 (1982) (applying principal-agent theory to liability rules). Although some legal commentators believe that agency theory is not testable, they are mistaken. For an insightful empirical application of an agency model, see M. Wolfson, Empirical Evidence of Incentive Problems and Their Mitigation in Oil and Gas Tax Shelter Programs (1983) (unpublished manuscript). 
corporate purpose. ${ }^{146}$ In one branch, the corporation is a device to coordinate individual efforts and it is evaluated by how efficiently it achieves that goal, as in pluralist models of the firm. In the other strand, the corporation is an evolving organism, whose major function is to provide social stability by harmonizing group interests, as in the corporatist approach. Consequently, corporate law reform premised upon organization theory concerns can promote either a pluralist or a corporatist ideal, depending upon the function attributed to the firm.

The application of organization theory to corporate law reform is an emendation of Berle and Means' project: By highlighting the potential divergence in interests among firm members, the identification of the separation of ownership and control necessitates a behavioral theory that delves inside firms. Both of the leading legal scholars working from an organization theory approach, John Coffee and Christopher Stone, explicitly recognize the link between their research program and Berle and Means' observation and view the separation as the source of the corporate irresponsibility that they seek to remedy. ${ }^{147}$ To the extent that they have harnessed the insights of organization theory to the Berle and Means' observation to argue for specific responsibility-generating reforms, the research strategy itself furnishes a partial and indirect explanation for the normative ambivalence that characterizes their proposals. As its critics and adherents have noted, organization theory is normatively weak. $^{148}$ Although it might provide an accurate description of the routines and bottlenecks within firms, it does not prescribe an ideal. Moreover, because the two schools in organization theory are not distinguished in the legal literature, the reform proposals contain both pluralist and corporatist elements.

The primary goal of the corporate law reform program inspired by organization theory is to devise mechanisms inside the firm to prevent information blockages that are thought to cause external diseconomies and corporate wrongdoing. Delegation and complexity are seen as the source of both the corporation's successful adaptation to modern industrial life and its serious communication problem. ${ }^{149}$

146. S. WOLin, supra note 8 , at $409-14$ (discussing organic and nonorganic branches of organization theory).

147. C. STONE, supra note 3, at 232-33; see Coffee, supra note 3 , at 393.

148. R. Nelson, The MoON AND the Ghetto $41-44$ (1977); Bower, Descriplive Decision Theory from the "Administrative" Viewpoint, in THE STUdY OF POLICY Formation 103, 130, 135 (R. Bauer \& K. Gergen eds. 1968).

149. Coffee, supra note 144, at 1148. As Coffee appears to adopt Oliver Williamson's 
Blockages are said to occur because employees pursue personal subgoals and thereby subvert the objective of the enterprise, by filtering out negative information as it travels up the chain of command. The organization theory reformers propose to mitigate this problem by creating new institutional arrangements whereby individuals positioned in the lower echelons of the hierarchy communicate directly with the board. Stone suggests designating a corporate officer to collect data at all levels within the organization and to present that information directly to the board. Coffee proposes establishing above operating divisions, miniboards composed of a director and outside experts. These miniature replicas of the board are to provide it with a means to obtain information independently from management and to reduce its distance from employees. Coffee and Stone anticipate that the establishment of internal linkages and interfaces between the board and employees, bypassing senior management, will ameliorate the institutional difficulties that prevent boards from performing an effective monitoring or supervisory role. The idea is that if the board has direct contact with individuals in the field, all information, good or bad, will be truthfully revealed to it.

Both Coffee and Stone explicitly use an organic metaphor and depict the board as the firm's "superego" to justify their approach. ${ }^{150}$ This reified corporate consciousness imparts a corporatist cast to their program. The board is the managing intellect of the corporate organism. At times, Coffee and Stone seek to align the interests of corporate managers with those of the public, an approach to the formulation of interests that is connected with organic theories of representation. ${ }^{151}$ In addition, the organization theory emphasis on formal roles and routines as the solution to incentive problems conflicts with the individualist values and organizational flexibility that are central elements of pluralism.

Yet the proposals also have features that undercut a fully-blown organic vision. For instance, the keystone of Stone's reformdesignation of a specific individual to gather and report information to the board, bolstered by a requirement that all reports be person-

efficiency explanation of the evolution of corporate structures, it is puzzling, if not contradictory, that he finds it necessary to mandate changes in those structures.

150. C. STONE, supra note 3, at 161 ; Coffee, supra note 144 , at 1144.

151. Furthermore, while discussing the impact of Berle and Means' separation thesis, Stone suggests that the observation itself is the cure for corporate irresponsibility because separation permits the emergence of managers responsible to public interests. C. STONE, supra note 3 , at 233 . This is the heart of the Berlian vision. 
ally signed ${ }^{152}$ - seeks to create a system of individual responsibility in order to control negative externalities produced by firms. A corporatist could use the pressures of a network of individual responsibility to ensure social stability through the coercive power and unity of the group, but Stone attempts to separate the individual's interests from the collective's when firm activities are harmful to third parties. The idea of individual responsibility that challenges, or is independent of, the promotion of group goals is foreign to an organic approach. Stone further advocates placing government inspectors inside the corporation to obtain information. Although this could initiate the close working relationship between state and industry of the corporatist ideal were the inspectors to be involved in coordinating production and investment decisions, Stone's apparent intention differs. His inspectors are to play a preventive informational role, serving as a pluralist market-correcting device to force the firm to internalize the social costs of its activities. Stone's concentration on externalities takes the corporatist edge off his proposals. ${ }^{153}$

Coffee's approach to reducing the information gap focuses on creating a responsible group, the miniboard, rather than on individual responsibility. ${ }^{154} \mathrm{He}$ documents the need for this procedure with findings of social psychologists that trust is greater among individuals who work in face-to-face groups. ${ }^{155}$ By putting employees in direct contact with board members, the miniboard is expected to provide a basis for developing the requisite trust in the board that will spur employees to divulge sensitive information.

Coffee's miniboard strategy is founded upon a belief that the use of a group-based solution is an efficient means of mobilizing individ-

152. Id. at 208. Stone requires a similar process, preparing a signed social impact statement, for all major corporate undertakings. Id. at 222-23.

153. In a more recent article, Stone has employed the public/private distinction to explain issues in corporate law, using organizational variables as the definitional constraint. Stone, Corporate Vices and Corporate Virtues: Do Public/Private Distinctions Matter?, 130 U. PA. L. REV. 1441 (1982). In doing so, he furthers a pluralist ideal, that there is a separate realm of private activity of which business corporations are a part, and he rejects the total conception of politics of organic thought that collapses the public/private dichotomy. Moreover, he also seeks to justify differential treatment of government (public) organizations in the context of constitutional claims by a theory of public goods, the paradigmatic pluralist approach.

154. Contending that this additional layer of hierarchy will not impair corporate efficiency, Coffee cites the success of Japanese corporations, in which groups and not individuals are said to control the decisionmaking process. Coffee, supro note 144 , at $1150 \mathrm{n} .184$. Apart from this emphasis on the use of a group as the institutional building block, the distinguishing feature of the Japanese ideal is its organic corporatist orientation. See generally M. Maruyama, Thought and Behaviour in Modern Japanese Polttics (1963).

155. Coffee, supra note 144 , at 1153 . 
ual action in the corporate context. But the focus on roles and on group decisions suggests that individualist concerns are of limited interest to him. His reform package cannot be clearly associated with a pluralist theory because he does not directly address a defining issue: In whose interest is individual action to be mobilized and firm efficiency to be enhanced? To state the ambiguity in the proposal more precisely, Coffee dues not articulate the objective function of the firm. He does indicate in passing that in some contexts shareholder interests are not determinative, but at other times he seems to be concerned solely with curbing production externalities in keeping with a pluralist approach. ${ }^{156}$ Both Coffee's and Stone's proposals for improving the corporation's information flow are therefore normatively ambivalent, for they can just as easily be given corporatist as pluralist interpretations.

\section{Modification of Role: The Debate Over Board Activity in Response to a Takeover}

The most recent surge in mergers has reinvigorated corporate law scholarship, inspiring a flurry of articles applying the new knowledge of financial economics as well as more traditional analysis. Not only does the drama of high-pressured, big dollar acquisitions catch everyone's fancy, but the takeover bid plays a crucial role in pluralist explanations of the firm as a check on agency costs. The issue that has generated the greatest interest is the appropriate role of the board

156. Some of Coffee's reforms seem only peripherally related to pluralist ends. His suggestion to spread adverse publicity, in the form of a public presentencing or probation report that details corporate misconduct, Coffee, supra note 3 , at $424-34$, is a technique foreshadowed by Berle. See Berle, supra note 44 , at 946 . In addition, the concept of corporate probation entails an organic perspective that reifies the corporate entity. Moreover, his goal of terminating employee subgoal pursuits forges for the firm a monolithic objective function that is not based on the aggregation of members' preferences. Finally, it is questionable whether his proposed equity fine, Coffee, supra note 3 , at 413-24, adds anything to current practices. The premise of the equity fine, that cash fines do not deter because they cannot be set high enough, is confusing. Coffee assumes that corporate bankruptcy is an inadequate deterrent, yet the loss of employment and the reputational damage of bankruptcy can hardly be less of a threat to a manager than the equity fine's incentive mechanism, being sacked by a successful tenderer. Moreover, if managers are risk averse as Coffee not unreasonably contends, then lower fines have a greater deterrent impact: For a given probability of detection, high fines "overdeter" risk averse individuals unless the probability of detection is extremely low. See A.M. PolinSKY, supra note 74, at 73-84. Further, although he recognizes that shareholders value the firm according to expected future earnings, he inexplicably assumes that lenders do not use the same valuation method when he contends that cash paid for a fine cannot be replaced by borrowing. Coffee, supra note 3, at 419. Finance theory teaches that expected future earnings are as crucial to creditors as to equity holders, and the firm's book value is equally unimportant to all investors. 
when a firm is the subject of a takeover. Important points of dispute include who benefits from takeovers and whose interests the board should consider in deciding whether to oppose a bid. The commentators can be schematically divided into two camps-those who wish to restrict board action, and those who wish to endow the board with wide discretion to respond to an offer. The positions have distinct normative foundations: The restrictive view very clearly attempts to further a pluralist ideal, and the discretionary view, in general, sustains a corporatist one.

The takeover bid: $A$ context for analysis. Henry Manne, in a classic article, was the first to articulate the importance of takeovers for pluralism. ${ }^{157}$ He contended that the market for corporate control is an essential safeguard for shareholders because it provides critical incentives that compel managers to maximize firm profits. Noting that share prices correlate with managerial performance, Manne maintained that when managers run a firm inefficiently, its stock price will decline. Someone else will then be able to increase share value and earn a hefty return, by acquiring control and installing more efficient managers. ${ }^{158}$ The two alternative methods to the takeover bid for replacing poorly performing managers, proxy fights and mergers, by contrast, are considered less effective devices for transferring control. Proxy fights are thought to be more expensive and less likely to succeed than tender offers, and mergers require the incumbent management's approval. This theory of takeover bids counters the contention that Berle and Means' observation of the separation of ownership and control casts doubt upon the ability of existing arrangements to promote shareholder interests and productive efficiency. A competitive market for corporate control creates sufficient incentives to ensure that the efficiency gains from hierarchical coordination flow through to shareholders and are not dissipated by management.

Although Manne's explanation of the modus operandi of takeovers suggests that a pluralist legal regime would seek to encourage takeovers and accordingly might place limits on the scope of managerial resistance, state corporation statutes are in the main silent concerning the directors' role in a takeover, and the federal regulatory

157. Manne, supra note 3.

158. To the extent that the market for acquirers is perfectly competitive, the investor may earn no more than an ordinary return. The findings that acquiring companies, unlike acquired firms, on average do not earn abnormal returns are often explained by such a hypothesis. See, e.g., T. COPELAND \& J.F. WESTON, supra note 82, at 601 . 
scheme imposes only conventional antifraud and disclosure duties on the boards of both sides of an offer. ${ }^{\text {is9 }}$ Presumably, the statutory framework does not sketch out specific duties for target management because tender offers bypass boards and go directly to shareholders. The fashioning of rules to guide board conduct has therefore devolved on courts, which preside over the skirmishes between incumbent managers and disappointed shareholders and tenderers.

The prevailing judicial attitude has been to tolerate broad defensive maneuvering, by a Byzantine application of the business judgment rule that skirts the issue of management's conflict of interest during takeovers. ${ }^{160}$ The common law of takeovers may be an anomalous instance of American legal rules undercutting pluralist arrangements. However, this is still a relatively unchartered area for litigation. Only one case explicitly adopts a perspective akin to corporatism: In Herald Co. v. Seawell, ${ }^{161}$ a federal appeals court upheld a series of defensive actions, asserting that the corporation, a newspaper company, was a "quasi-public institution" with an obligation not solely to shareholders but also to employees and the public. ${ }^{162}$ But the legal rules and counter-rules are still very much in flux, as the array of intricate tactics winds its way through the courts towards resolution. Moreover, although there is a cogent pluralist view of takeover bids, there is still no comprehensive behavioral theory of the corporate merger phenomenon, of which takeovers are but a conspicuous subset. The inadequate development of a theory of mergers undoubtedly contributes to judicial uneasiness over extensive meddling in takeovers.

Giving the board a role: $A$ corporatist perspective. A number of commentators have endorsed board efforts to prevent their companies from being taken over. ${ }^{163}$ These writers contend that an active board

159. The federal regulation is contained in the Williams Act, 15 U.S.C. $\$ \S 781(i)$, $78 \mathrm{~m}$ (d)-(e), 78n(d)-(f) (1982). Many state statutes do aid target management, however, by imposing, among other features, administrative review requirements on bids.

160. E.g., FMC Corp. v. R.P. Scherer Corp., No. 82-461 (D. Del. Aug. 5, 1982); Panter v. Marshall Field \& Co., 486 F. Supp. 1168 (N.D. Ill. 1980), affd, 646 F.2d 271 (7th Cir. 1981), cert. denied, 454 U.S. 1092 (1981). There are only a few exceptions. E.g., Mobil Corp. v. Marathon Oil Co., 669 F.2d 366 (6th Cir. 1981); Klaus v. Hi-Shear Corp., 528 F.2d 225 (9th Cir. 1975). For a very lucid presentation of the developing doctrine, see Gilson, $A$ Structural $A p$ proach to Corporations: The Case Against Defensive Tactics in Tender Offers, 33 STAN. L. REV. 819, 824-31 (1981).

161. 472 F.2d 1081 (10th Cir. 1972).

162. Id. at 1091, 1094-95. The decision may be an anomaly because it involved the press, which is often said to possess a special constitutional status.

163. See, e.g., Lipton, Takeover Bids in the Target's Boardroom, 35 Bus. Law. 101 (1979); 
role is necessary because a wide spectrum of noninvestor interests should be considered in the evaluation of an offer. Their proposals do not, however, provide for the direct input of nonshareholder constituencies. They presume that the board is capable of independently and dispassionately discovering and harmonizing the interests of the relevant groups. In addition, these analysts dispute the takeover's role as a disciplining device. They believe instead that tender offers generally serve no useful function and are undertaken by acquirers with larcenous intentions. Hence, as a means of fending off such attacks, they seek to strengthen the centralized command structure of the target firm and identify top management as the locus of authority for decisions concerning a bid.

Almost all proposals supporting board intervention are infused with the imagery and rhetoric of corporatism. For instance, a prominent advocate of defensive maneuvering, Martin Lipton, maintains that active management resistance to takeovers is justified by the interest of the "nation's corporate system and economy," which is of greater concern than the interests of the individuals comprising the particular corporation. ${ }^{164} \mathrm{He}$ contends that the board is responsible to shareholders with long term and not short term interests, "other constituencies," which include employees and local communities, and the interest of the "company as a business enterprise." 165 These different constituencies are not placed in direct contact with the board; it acts on its own to identify and implement the socially optimal decision. During his tenure as Chairman of the SEC, Harold Williams also asserted that the interests of employees, suppliers, communities, and the general public, and not just shareholders, should enter into the board's decision regarding its takeover response. ${ }^{166}$ Williams rejects the idea that shareholders should have the right to decide the outcome of a tender offer, and that their economic interests should be controlling. Instead, he insists that the directors should decide on a course of action based on their "assessment of the corporation as an institution with responsibilities to discharge, [to the economy and various other groups] rather than simply [seek] the best deal for their shareholders." 167 The corporation is thought to be an

Steinbrink, Management's Response to the Takeover Altempt, 28 CASE W. RES. [L. REv.] 882 (1978); Speech by Harold Williams Before the Seventh Annual Securities Regulation Institute (Jan. 17, 1980), reprinted in [1979-1980 Transfer Binder] FED. SEC. L. REP. (CCH) I] 82,445 .

164. Lipton, supra note 163 , at 104.

165. Id. at 104, 106, 115.

166. Williams, supra note 163 , at 82,881 .

167. Id. at 82,879 . 
entity with its own interests, distinct from those of its owners, and it is charged with promoting the "public interest," which is presumed to be objectively knowable by the public-spirited board members. ${ }^{168}$ The image of the director as the guardian and spokesperson for society's interest at the core of both Lipton's and Williams' positions is evocative of Berle's vision of the magnanimous civil servant manager.

Another proponent of an active defensive board, William Steinbrink, makes the connection to Berle even more explicit. ${ }^{169}$ Steinbrink starts from the proposition that the separation of ownership and control requires a redefinition of the shareholders' position as one subordinate to professional management in the direction of corporate affairs. Possessing a leadership role in the shaping of corporate policy, management is held accountable to societal interests ranging far beyond the interests of shareholders. ${ }^{170}$ The progression of Steinbrink's analysis thus parallels Berle's development of the vaunted position of the public-spirited manager. Because a takeover may affect employees and other individuals interested in the business besides shareholders, Steinbrink contends that the decision must be made "by the entity acting through the management rather than occurring as a consequence of uncoordinated individual actions by shareholders." ${ }^{771} \mathrm{He}$ further invokes an organic metaphor in his imagery of a takeover as an invasion of the corporate body, noting that managers perceive tenderors as "carcinogenic."172 The noninvestor interests that the board must consider when determining whether to reject even an adequately priced offer include not only the interests of the local community but, amusingly, management's own interest in retaining control. There is little attention given to the property rights of the corporation's owners, the foundation for the pluralist perspective.

Taken as a whole, however, Steinbrink's proposals are confusing. He gives the board free rein to respond to a bid, and advocates adoption of shareholder resolutions declaring that the interests of the cor-

168. Williams proposes that an independent board render the decision on a tender offer response. Id. Given his conception of the board's representation of interests, his use of independent directors is closer in spirit to the public and special interest director reforms than to the independent directors Eisenberg advocates. When independent directors are envisioned as a professionalized cadre that implements the interest of the collective entity, their role is indistinguishable from a public interest director. For an example, see Moscow, The Independent Director, 28 Bus. LAw. 9 (1972).

169. Steinbrink, supra note 163.

170. Id. at 884 .

171. Id. at 896 (emphasis added).

172. Id. at 897 . 
poration's shareholders, employees, and surrounding communities are best served by the company's independence. But he then recommends subjecting tender offers to a majority vote of the shareholders. Such a requirement is inconsistent with the balance of the proposal that attaches little weight to shareholder preferences, as his critics have been quick to point out. ${ }^{173}$ In addition, the voting requirement restricts the freedom of investors to reach their own decision to sell.

In contrast to the pluralist theory of takeovers, the assumption underlying the firm independence resolutions that Steinbrink supports is that takeovers do not benefit shareholders. Yet in adopting this view, Steinbrink does not even address the agency problem in corporate law and the incentive effects of the market for corporate control; they pass unrecognized, or are ignored or misunderstood. The ultimate effect of Steinbrink's plan is to substitute a majority of the shareholders for managers, as the representatives who are to divine selflessly the public interest.

One proposal endorsing an active role for the board stands apart from the others in its normative premises. Herzel, Schmidt, and Davis, unlike the other proponents of defensive tactics, advocate board action from a pluralist conception. ${ }^{174}$ They support defensive resistance by the board on the ground that such activity benefits shareholders by increasing the offer price. In their scenario, the board must serve as the shareholders' bargaining agent because shareholders are trapped in a prisoners' dilemma, a game in which the dominant individual strategy of noncooperation (immediately tendering) leads to suboptimal results: a greater share of the gains will go to the acquiring corporation than to the target's owners. This is yet another variant of the pluralist public goods rationale for intervening in markets to maximize individual returns. However, Herzel and his coauthors acknowledge the agency problem, the board's powerful self-interest in bolstering its position at the expense of the shareholders while serving as negotiator, and they are ultimately unable to recommend without substantial qualification any simple rule for director conduct. ${ }^{175}$ Their difficulties in formulating a straightforward, coherent policy suggest that a pluralist perspective may more readily support a restrictive approach to defensive board action.

173. Lynch \& Steinberg, The Legilimacy of Defensive Tactics in Tender Offers, 64 CoRNelL L. REv. 901,911 (1979).

174. Herzel, Schmidt \& Davis, Why Corporate Directors Have a Right to Resist Tender Offers, 3 CORP. L. REv. 107 (1980).

175. Id. at $115-16$. 
Restricting the board's role: Towards a pluralist ideal. Two leading articles, one by Frank Easterbrook and Daniel Fischel ${ }^{176}$ and the other by Ronald Gilson, ${ }^{177}$ reject any significant role for the board in defending against a tender offer. Both proposals are the product of a commitment to the pluralist ideal and its corresponding conception of the corporation. ${ }^{178}$

Easterbrook and Fischel ground their thesis, that the proper role for the board is a passive one, in the proposition that defensive tactics decrease shareholder welfare. They develop the Henry Manne insight that takeovers increase shareholder wealth by replacing inefficient managers with more efficient ones. Theirs is an individualist perspective: The corporation is characterized as a contractual arrangement that promotes the interests of investors, and the board is to represent solely those interests. ${ }^{179}$ This pluralist approach to the corporation sets the board's objective as maximizing the shareholders' wealth, a goal that requires ensuring the viability of the takeover mechanism as a constraint on management behavior. Consequently, shareholders alone are to make the decision whether to tender their shares.

Easterbrook and Fischel rely on the findings of financial economics of substantial gains to target shareholders to support their position. They contend that takeovers are beneficial because bids involve moves towards more efficient allocations of resources. Forcing competition, takeovers mitigate the incentive compatibility problem posed by the separation of ownership and control. Hence, Easterbrook and Fischel maintain that removing defensive strategies from the target board's arsenal will result in the corporation performing more efficiently, advancing the interests of its owners. The use of corporate finance as an aid for charting the directors' appropriate

176. Easterbrook \& Fischel, The Proper Role of a Target's Management in Responding to a Tender Offer, 94 HaRv. L. Rev. 1161 (1981).

177. Gilson, supra note 160.

178. The text discusses the articles by Easterbrook and Fischel and by Gilson because they present the most careful and comprehensive reform proposals on board takeover tactics within a fully specified normative framework. Other proposals, using a more traditional approach, also emanate from pluralist premises and try to devise limits on board defensive activities. These studies start from the presumption that the takeover decision is within the realm of shareholder and not managerial decisionmaking, and emphasize the freedom of choice of individual investors as the basis for restricting director responses. See Gelfond \& Sebastian, Reevalualing the Duties of Target Management in a Hostile Tender Offer, 60 B.U.L. REv. 403 (1980); Lynch \& Steinberg, supra note 173.

179. Easterbrook \& Fischel, supra note 176 , at 1170 n.26, 1191. 
role, a methodology whose relation to pluralism has been discussed, reinforces the pluralist premises of the proposal.

Gilson's approach to the problem is also that of a pluralist. $\mathrm{He}$ determines the board's role by a structural analysis, which locates the corporate hierarchy within a series of markets and pinpoints the takeover bid as the crucial mechanism for constraining managers to act in the shareholders' interests. These conditions diminish the significance of the separation of ownership and control. Gilson also uses the learning of financial economics to develop his position. In his view, the takeover bid is primarily a means for achieving synergistic efficiency gains. While he does not explicitly state that the objective of his takeover policy is to increase shareholder welfare, that is its intended result. He would restrict the board's role to actions that aid shareholders in deciding whether to tender. The board would be permitted both to provide information shareholders need to reach an intelligent decision and to serve in a limited fashion as bargaining agent because the shareholders' dispersed numbers prevent them from negotiating effectively. ${ }^{180}$

From this shared normative framework, Easterbrook and Fischel and Gilson agree on the general parameters of reform-banning management defensive tactics-but they disagree over the choice of the mechanism for implementing their common end. While Easterbrook and Fischel require close to total passivity, Gilson would allow the board to solicit competing bids. ${ }^{181}$ As is true of other policy disputes among pluralists, the disagreement is a function of differing factual assumptions. ${ }^{182}$ Easterbrook and Fischel oppose bidding auctions because they believe that auctions will reduce the incentives to invest in the information-gathering activities that identify takeover targets. ${ }^{183}$ Consequently, they assert that such a policy will decrease the number of takeovers, and therefore will fail to maximize shareholder wealth. Gilson contends that competitive bidding would in-

180. Gilson, supra note 160 , at $865-75$. Gilson rejects the contention that the tender offer is a prisoners' dilemma game. Id. at 859-62.

181. Easterbrook \& Fischel, Auctions and Sunk Costs in Tender Offers, 35 STAN. L. REV. 1 (1982); Gilson, Seeking Competitive Bids Versus Pure Passivity in Tender Offer Defense, 35 STAN. L. REV. 51 (1982).

182. See, e.g., notes 102-105 supra and accompanying text, and notes 246-247 infra and accompanying text. An interesting question is why controversies based upon diverging empirical contentions frequently appear among pluralists. Of all the ideal types, pluralism may be the only one that is susceptible to empirical falsification due to its emphasis on experimentation and its individualistic theoretical orientation. This is because individual facts can disprove a hypothesis whereas social facts cannot. See, e.g., M. LEssNoff, supra note 16, at 76-78.

183. Easterbrook \& Fischel, supra note 181, at 3-17. 
stead increase allocative efficiency: Maintaining that the returns to collecting information about targets and the number of tender offers will not decline, he counters that a policy encouraging auctions will augment shareholder welfare, as the firm's assets will move to their highest-valued use. ${ }^{184}$ If we knew which way auctions cut, that is, if data on costs were compiled and the competing hypotheses concerning the effect of auctions on takeover bids were tested, then the dispute over the optimal rule could be settled. ${ }^{185}$ Unlike disagreement over political ideals, when the controversy concerns the empirical basis for implementing a particular ideal it is in principle capable of consensual resolution.

Although a policy of restricting board action seeks to implement pluralist ends, a pluralist could advocate that the state should not be involved in making choices regarding permissible defensive tactics from a survivorship view of the world, that voluntary arrangements that persist tend to be efficient. Such a position is in keeping with an enabling approach to state corporation codes, that laws should serve to facilitate individual contracting and not to restrict it. From the survivorship perspective, the continued presence of antitakeover devices is probative evidence of their benefiting shareholders. ${ }^{186}$

The multiplicity of pluralist policy options concerning defensive tactics makes painfully obvious the need for the testing of theories. The sharply contrasting responses turn on differences in both the characterization of the severity of the agency problem and the inference drawn from observed behavior, whether private arrangements are thought to be efficient or more akin to a prisoners' dilemma. In the debate among pluralists, the adequacy of present checking mechanisms-markets, contracts and judicially-construed fiduciary du-

184. Gilson, supra note 181 , at 52-64.

185. Lucian Bebchuk has advanced a position similar to that of Gilson in Bebchuk, The Case For Facilitating Competing Tender Offers: A Reply and Extension, 35 STAN. L. REv. 23 (1982). The empiricist nature of the controversy between Bebchuk and Easterbrook and Fischel is a result of their subscription to different theories of information. Easterbrook and Fischel accept the conventional public goods theory that information and innovation will be undersupplied, whereas Bebchuk adopts the more recent learning that invention and information may in fact be oversupplied. See Dasgupta \& Stiglitz, Industrial Sinucture and the Nalure of Innovative Activity, 90 Econ. J. 266 (1980); Hirshleifer, The Private and Social Value of Information and the Reward to Inventive Activity, 61 AM. ECON. REv. 561 (1971).

186. The primary benefit is to guarantee higher acquisition premiums. The effectiveness of the market to ensure that only tactics favorable to shareholders survive depends, in part, on whether mistaken management resistance does not deter subsequent offers. For a study finding that defensive tactics increase shareholder wealth see Linn \& McConnell, $A n$ Empirical Investigation of the Impact of "Antilakeover" Amendments on Common Slock Prices, $11 \mathrm{~J}$. FiN. ECON. 361 (1983) (defensive charter amendments). 
ties-to restrain managerial self-dealing in takeovers remains a troublesome technical question. Without a positive theory of mergers that can predict the likely effects of different takeover policies, there may be good cause to fall back on a simple rule of thumb: not to interfere extensively with private decisions in the absence of a greater consensus on the probable consequences of our actions.

\section{III.}

In addition to proposals to alter the internal arrangements of firms under state corporation laws, many current issues of corporate law reform involve federal regulation of business activity. This section explores three such areas and connects the major controversies to the ideals. It considers, in turn, federal taxation in the context of the debate over the integration of the corporate and personal income tax, restrictions on corporate political action, and regulation of the issuance and trading of securities under the federal securities laws.

\section{A. Taxation of Corporate Income}

Although integrating the corporate and personal income tax is not usually perceived as a corporate law issue, the positions for and against integration, or more accurately, their supporting metaphors, can be identified with different conceptions of the corporation that are grounded in divergent ideals. In brief, an integrated tax is in keeping with a pluralist view, whereas the existing treatment of corporate income evokes the organic perspective of corporatism. To be sure, the technical criteria for assessing the optimality of specific taxes, efficiency and equity, as well as revenue-generating capacity, are distinct from the metaphors. Moreover, pragmatic considerations concerning whether an integrated tax is administrable and what kinds of taxes the legislative process can support may be the most important factors for scholars who defend the corporate tax. But the metaphors are instructive because they have penetrated the academic debate, and they shape our preconceptions of what is just or equitable tax treatment.

The current system of taxation of corporate income consists of a two-tier structure. Corporate income is taxed once at the corporate entity level when it is earned, and then it is taxed again at the individual level when it is distributed to the shareholders. Although the two level tax is deeply embedded in our political system, its conceptual roots are close to corporatism because a two-tier regime implicitly adopts an organic perspective. It presupposes that a corporation 
is a distinct entity, separate from its owners, and therefore separately taxes the income of each. ${ }^{187}$ This organic component can be traced to the tax's origins: The corporate income tax was adopted during a high point in the American progressive movement, which espoused a world view similar to Berle's and had as a policy objective state control and coordination of large corporations. However, of greater analytical import is the form of the argument made in favor of the twotier tax. In one of the better known defenses, Richard Goode supported the corporate tax by invoking Berle and Means' research. In his view, the organizational developments outlined by Berle and Means justified separate taxation, by demonstrating both the limited claim of stockholders to a share of corporate profits and the realism of attributing to large corporations a life independent from their owners. ${ }^{188}$ Furthermore, advocates of the two-tier regime like Goode join the concession view of the corporation to the benefit principle of taxation in order to uphold the corporate tax. They characterize the tax as a payment for the benefits corporations receive from the state, including protection of property rights and special "privileges" conferred by incorporation such as limited liability. ${ }^{189}$

The periodically proposed shift to an integrated tax involves a radically different system from the corporate tax both in operation and conception, although it is the tax model already in place for partnerships, subchapter $S$ corporations, trusts, and, in varying degrees, cooperatives and financial intermediaries. In an integrated tax, corporate income is passed through to the shareholders and taxed only once, at the individual level.

Conceptually, integration is a pluralist policy, for it is an application of the individualist contract approach to corporations to the tax treatment of income. Advocates of integration recognize that taxes are ultimately borne by individuals and that a corporation is nothing more than the individuals who comprise it. They view the corporation as a conduit: It is merely the aggregate of its owners and has no

187. R. GoOde, The Corporation Income TaX 203 (1951); see C. MCLure, Must CORPORATE INCOME BE TAXED TWICE? 28-29 (1979) (describing anti-integration position as entity view); Warren, The Relation and Integration of Individual and Corporate Income Taxes, 94 HARV. L. REv. 717, 719 (1981) (same).

188. R. GoODE, supra note 187, at 16-23. Goode used the Berle and Means separation thesis to invoke an entity conception of the corporation as the normative basis for its taxation and not simply as an empirical observation that could be used to generate increased federal revenues.

189. Id. at 27-30; see Break, Integration of the Corporate and Personal Income Taxes, 22 NAT'L TAX J. 39, 39 (1969). 
distinct existence. ${ }^{190}$ A corporation can therefore have no separate taxpaying capacity beyond that of its shareholders, and, as a result, taxing corporate income at the entity level would violate accepted tax principles of ability-to-pay and horizontal and vertical equity. ${ }^{191}$ The strength of this connection has been emphasized by a leading authority on integration, Charles McLure, who asserts that "once the conduit view [of the corporation] is rejected, the conceptual case for integration is weakened considerably." 192 The metaphors that frame the debate thus link a policy of integration to pluralist premises and the present corporate tax to a corporatist perspective.

\section{B. Regulation of Political Activity}

A labyrinth of federal and state regulations governs corporate activity in election campaigns. The regulation has been spurred in large part by apprehension that corporations could dominate the electoral process if their campaign spending went uncurbed. ${ }^{193}$ By examining the normative implications of the approach taken to corporate campaign expenditures by Congress, the Supreme Court, and their critics, this section probes the relationship between corporate political expression and pluralism.

The context of the debate on corporate political speech. Direct corporate financial participation in federal elections has been prohibited since 1907 , and several states have similar bans that also date from the progressive era. ${ }^{194}$ Many other states simply impose dollar limitations on corporate giving. ${ }^{195}$ Yet federal law does not bar all corpo-

190. Gabinet \& Coffey, The Implications of the Economic Concept of Income for CorporationShareholder Income Tax Systems, 27 CASE W. RES. L. REv. 895, 914 (1977); McLure, Integration of the Personal and Corporate Income Taxes: The Missing Element in Recent Tax Reform Proposals, 88 HaRv. L. Rev. 532, 535 (1975); Waggoner, Eliminating the Capital Gains Preference. Part II: The Problem of Corporale Taxation, 49 U. COLO. L. REV. 9, 18 (1977); Warren, supra note 187, at 720.

191. McLure, supra note 190 , at 535.

192. C. McLuRE, supra note 187 , at 28 . Several nations have adopted partially integrated systems, including some with strong corporatist intellectual traditions, such as Germany and Japan. But the entity/aggregate distinction shapes only the American discussion. The foreign rationale for integration apparently does not adopt the conduit theory. For instance, the West German government, in proposing partial integration, explictly rejected the conduit approach and its attack on the separate entity view. See id. at 44.

193. See, e.g., Wright, Politics and the Constitution: Is Money Speech?, 85 Yale L.J. 1001 (1976); see generally C. LiNdBLOM, Polmtics AND MARKETS 170-221 (1977).

194. See Lambert, Corporale Political Spending and Campaign Finance, 40 N.Y.U. L. REv. 1033, 1035 (1965); Wallace \& Stamps, Corporate Free Speech and Campaign Finance in Mississippi, 49 Miss. L.J. 819, 821-23 (1978).

195. Wallace \& Stamps, supra note 194 , at $821-23$. 
rate disbursements. The revolution in campaign financing laws in the aftermath of the 1972 Nixon reelection campaign scandals expressly authorized corporate underwriting of three types of political activity when directed solely towards shareholders and executivelevel personnel: partisan communications; nonpartisan voter registration and "get out the vote" drives; and, most important, the establishment, operation, and solicitation of contributions to a "separate segregated fund" called a political action committee (PAC). ${ }^{196}$ The principal effect of the legislative scheme is that corporations may participate in federal election campaigns indirectly, by defraying the expenses of their PACs.

The regulatory movement was dealt a severe setback, however, by two Supreme Court decisions. In Buckley v. Valeo, ${ }^{197}$ the Supreme Court considered a host of challenges to the newly enacted federal campaign financing legislation that contained the corporate PAC provision, and struck down as unconstitutional limits on political expenditures, while upholding limits on campaign contributions. Hence, under Buckley, PAC expenditures that are made independently of a candidate's campaign cannot be restricted. Two years later in First National Bank of Boston v. Bellotti, ${ }^{198}$ the Court reviewed a Massachusetts statute banning corporate expenditures on state referenda that did not materially affect the corporation's business, and held that the prohibition violated the first amendment's guarantee of freedom of expression. The decision made explicit Buckley's reach to corporate donors and state forums.

Opponents of corporate political activity have vigorously criticized Bellotti, typically on the ground that the Court did not decide whether corporations have the same constitutional rights as natural persons. ${ }^{199}$ The implicit assumption is that had this issue been joined, the Court would have somehow distinguished corporations from people and the decision would have gone the other way. Addi-

196. 2 U.S.C. $\$ 441 \mathrm{~b}$ (1976).

197. 424 U.S. 1 (1976). The Court upheld reporting and disclosure requirements and public financing of presidential elections that imposed expenditure limits upon candidates accepting the funds. It did not rule on the constitutionality of the prohibition of direct independent expenditures by corporations. But this may not be a serious matter in practice because corporate PACs have tended to spend their funds on direct contributions and have not engaged extensively in independent campaign spending. Epstein, Business and Labor under the Federal Election Campaign Acl of 1971 , in PARTIES, INTEREST Groups, AND CAMPAIGN FINANCE LAwS 107, 126 (M. Malbin ed. 1980).

198. 435 U.S. 765 (1978).

199. E.g., Patton \& Bartlett, Corporate "Persons" and Freedom of Speech: The Political Impact of Legal Mythology, 1981 WIS. L. REv. 494. 
tional commentators, rereading Buckley's holding on expenditure limits in light of Bellotti's position on corporate speech, have expended great energy debating the constitutionality of existing restrictions on direct corporate campaign expenditures. ${ }^{200}$ But when corporate political action is analyzed in the context of corporate law reform, two factors overwhelm the import of such esoteric doctrinal distinctions. First, many of the Court's critics have a perception of the political process and of corporations that conflicts with the pluralist vision of Bellotti. Second, formulating a coherent policy towards corporate political speech requires an understanding of profoundly practical and behavioral questions concerning the effects of campaign financing on election outcomes and the ramifications of the relatively new phenomenon on the political scene, PACs.

Indeed, corporate PACs have become the bete noire of those interested in campaign financing reform under the banner of ridding the electoral process of the distasteful taint of money or corporate influence. An important reason why the attack on corporate PACs has intensified over time is that they have flourished in comparison to labor PACs. Unlike corporations, unions had established political committees to circumvent the direct expenditure ban prior to the 1970's reform legislation, and consequently, union PACs have little potential for growth. Hence, with union PAC numbers remaining fairly constant over the years, labor's proportion of total PAC spending has steadily declined. ${ }^{201}$ Although "non-connected" PACs such as trade association, health, and ideological committees accounted for the largest increase in PAC activity in the last decade, ${ }^{202}$ challenges to the role of the committees in campaigns have emphasized corporate PACs. A credible, though incomplete, explanation of this slant is that because of the tremendous resources of large corpora-

200. E.g., Birnbaum, The Constitutionality of the Federal Comupt Practices Act After First National Bank of Boston v. Bellotti, 28 AM. U.L. Rev. 149 (1979); Cox, Foreword: Freedom of Expression in the Burger Court, 94 HARV. L. REv. 1, 67-70 (1980).

201. Epstein, supra note 197, at 115-20; Epstein, An Irony of Electoral Reform, REgulaTION May-June 1979, at 35; G. JaCOBSON, MONEY IN CONGRESSIONAL EleCTIONS 230-31 (1980).

202. Jacobson, Money in the 1980 and 1982 Congressional Elections, in Polrtical Finance IN THE 1980's (M. Malbin ed. forthcoming). The data on PACs tend to cut against the thesis that corporations dominate politics and politicians. The dollar contribution of PACs is small, both per campaign and in the aggregate. Malbin, Of Mountains and Molehills: PACs, Campaigns, and Public Poligy, in Parties, InTerest Groups, and Campaign Finance Laws, supra note 197, at 152, 169; see Jacobson, supra (Table 1, giving percentages). For instance, total contributions from PACs were less than 1/3 of all contributions in 1982. Id. Moreover, individual corporate PACs are seldom in the "top ten" PACs as measured by campaign contributions. H. Alexander, Financing Politics 97 (3d ed. 1984). 
tions and the sheer numbers of incorporated businesses, each of which can form a PAC, critics fear that if this financial and organizational potential was ever mobilized, the present political equilibrium among interest groups would be upset.

Frustrated by the constitutional principle of Buckley and cognizant of the burgeoning activity of PACs, foes of corporate political speech have advanced several proposals to stem the growth of PACs, such as lowered PAC campaign contribution ceilings and publicly financed congressional election campaigns conditioned on the candidate's accepting expenditure limits. ${ }^{203}$ But political analysts and scholars worried less about corporate PACs and more about the pressing problems of increasing political polarization, the languishing of political parties, and an ever-expanding pork barrel sustained by interest group politics, see the problem differently. In brief, the problem with the financing of campaigns is not too much money but too little: Challengers need more money than incumbents to win. The financing reforms of the 1970's benefited incumbents, whose likelihood of reelection is inversely correlated with the amount of funds expended by challengers, and additional limitations on contributions will only enhance the incumbent's edge. ${ }^{204}$ Moreover, the reelection of incumbents, and specifically, their margin of victory, has steadily increased over time. ${ }^{205}$ Hence, analysts have recommended raising individual campaign contribution ceilings, which are now lower than those for PACs, and publicly financing campaigns

203. E.g., Wertheimer, The PAC Phenomenon in American Politics, 22 ARIz. L. REv. 603 (1980); Wright, Money and the Pollution of Politics: Is the First Amendment an Obstacle to Political Equality?, 82 Colum. L. REv. 609 (1982). For a variety of reform proposals, see the symposium in PARTIES, INTERest Groups, AND CAMPAIGN FinANCE LAWS, supra note 197. Although labor PACs are the only PACs that have made contributions that reach the statutory maximum, they favor reduction of the ceilings and public financing presumably because of their comparative advantage in providing nonfinancial campaign support, such as registering voters and getting out the vote. See Epstein, supra note 197, at 147; Jessup, Can Political Infuence Be Democratized? A Labor Perspective, in PARTies, Interest Groups and Campaign FiNANCE LAWS, supra note 197 , at $26,42-44$.

204. G. JACOBSON, supra note 201 , at $48-49,157,194$. Republicans tend to vote against campaign financing restrictions, although, restrictions would be in their individual interest as incumbents. However, the Republican party raises funds much more effectively than the Democratic party. Jacobson, supra note 202. Moreover, not only are there more Democratic incumbents, but there are more registered Democrats. Consequently, in order to win, Republican candidates must provide more information to voters, and thus must campaign more, which means spending more money. Determining causation between successful election and campaign funds is, however, illusive. For instance, we do not know whether a candidate's ability to attract votes attracts money, or whether it is the money that attracts the votes.

205. M. Fiorina, Congress: Keystone of the Washington Establishment 5-11 (1977); G. JACOBSON, supra note 201, at 1-4. 
without limiting private funding sources, in order to offset the power of all organized groups and the advantage of incumbency. ${ }^{206} \mathrm{Al}-$ though no campaign financing policy can be absolutely neutral between candidates-incumbents or challengers, Democrats or Republicans-legislation whose probable effect is further to entrench incumbents is particularly worrisome for pluralists because it erodes the most potent disciplining force for rendering officials accountable, candidate competition. ${ }^{207}$ In this regard, the Court's decisions limiting the reach of campaign regulation plugged the proverbial hole in the dike: Campaign financing limitations can pose a serious threat to the homeostatic quality of democratic politics.

\section{The attack on corporate political speech as an objection to a pluralist poli-} tics. The observation that regulation of political activity tends to favor incumbents is not terribly counterintuitive, since incumbents, who typically aspire to be reelected, enact the laws. Yet critics of corporate PACs, and of Bellotti, never seriously confront this problem. ${ }^{208} \mathrm{~A}$ common disdain for politics that is prevalent among opponents of corporate political speech may explain the failure: Most of these critics have an aversion to interest group politics, and view corporate interests as in conflict with their perception of a public interest. $^{209}$

This antagonism to interest group politics and to for-profit firms is conspicuous in objections to Bellotti. The Bellotti majority had em-

206. E.g., Malbin, supra note 202, at 180-84; The InSTITUTE of POLITICs, JoHN F. KENNEDY SCHOOL OF GOVERNMENT, HARVARD UNIVERSITY, AN ANALYSIS OF THE IMPACT of the Federal Election Campaign Act, 1972-78: A Report by the Campaign FiNance Study Group to THE CoMmittee on House Administration OF the U.S. HOUSE OF REPRESENTATIVES (May 1979); see G. JACOBSON, supra note 201, at 179-226. Proposals to offset PACs by strengthening political parties include repealing the limits on contributions to and expenditures by parties, and making parties, not candidates, the recipients of public financing. H. ALEXANDER, supra note 202, at 107-08, 190-91.

207. See J. Schumpeter, Capitalism, Socialism and Democracy 269 (1947); M. Weber, Buteauctagy, in From MAX Weber: EsSAys in SOCIOlOGY 196, 226 (1946).

208. E.g., Wright, supra note 203. After criticizing corporate PACs for financing incumbents and not challengers, Judge Wright proposes limiting PAC expenditures and public financing conditioned on campaign spending limitations, which, as discussed in the text, would only further entrench incumbents. Although corporate PACs, like most campaign contributors, generally favor incumbents, Epstein, supra note 197, at 139, there is some diversity in their spending patterns and the funding of open seat races, Malbin, supra note 202, at 164-69. Proposing limitations on corporate PACs on the ground that their contributions exacerbate the incumbency effect proves too much, since that charge can just as easily be directed against all campaign contributors, not just corporate and union PACs, but individuals as well.

209. Wertheimer, supra note 203; Wright, supra note 203; see C. LINDBLOM, supra note 193. 
phasized the content of speech, rather than the identity of the speaker, in concluding that the rights of hearers (the voting public) to an open and informed political discourse are jeopardized by a prohibition on corporate political expression. Commentators have challenged the Court's approach by focusing on the speaker, contending that corporations are legal fictions, which cannot speak or have ideas, and consequently, cannot engage in protected first amendment activities. $^{210}$ This critique is usually joined to a concession view of corporations. Critics argue that although regulation would be inappropriate if the speaker was an individual, because state law grants corporations the right to exist and to accumulate the capital they spend in elections, the state can correspondingly restrict corporate political activity. ${ }^{211}$ Few commentators adopt a contract approach, which would ascribe the shareholders' rights of political speech to their corporate agents. ${ }^{212}$ Instead, they reify the corporation, treating it as distinct from the individuals comprising it.

These critics, however, have not tied their organic conception of a business association to an alternative vision to pluralism. This is undoubtedly related to the constraints on the debate in which they are engaged: The core concerns of the first amendment, protecting a person's right to speak on political matters, are formulated in individualist terms. In fact, most commentators who find fault with $\mathrm{Bel}$ lotti assert theories of the amendment's purpose that stress individuality and the values of self-realization and self-expression. ${ }^{213}$ Yet by concentrating on the individualist pole of the pluralist ideal that is expressed in the first amendment's free speech clause, the critics advance a truncated pluralist vision. They overlook pluralism's organizational dimension, which sees a need for individuals to organize into groups, a dimension enshrined in the free association branch of first amendment analysis. ${ }^{214}$ As a consequence, the critics would

210. E.g., Baker, Commercial Speech: A Problem in the Theory of Freedom, 62 IowA L. Rev. 1 (1976); O'Kelley, The Constitutional Rights of Corporations Revisited: Social and Political Expression and the Corporation after First National Bank v. Bellotti, 67 GEO. L.J. 1347 (1979); Patton \& Bartlett, supra note 199.

211. E.g., Patton \& Bartlett, supra note 199, at 496, 502; First National Bank of Boston v. Bellotti, 435 U.S. 765, 824 (1978) (Rehnquist, J., dissenting).

212. The exception is The Supreme Court, 1977 Term, 92 Harv. L. Rev. 1, 165-67 (1978). The criticism of Bellotli from a managerialist perspective can be related to a contract approach as well. See notes 218-220 infra and accompanying text.

213. E.g., Baker, Scope of the First Amendment Freedom of Speech, 25 U.C.L.A. L. REv. 964, 990-1009 (1978); Redish, The Value of Free Speech, 130 U. PA. L. Rev. 591 (1982).

214. C. Edwin Baker, for example, having formulated a theory of the first amendment derived from the values of individual self-expression and fulfillment, maintains that corporate speech is entitled to no constitutional protection. Baker, supra note 210. He contends that 
deny the most effective means of political participation available to individuals who have ordered their affairs in business firms, engaging in collective action through their corporation.

Political action at the entity level is important because it can avoid the free rider problem besetting individual action by corporate owners, the mismatching of individual costs and benefits because the objects of politics are public goods. When a group undertakes political activity, the costs, as well as benefits, are shared proportionately by all members, and the optimal level of action can be achieved. The critics of Bellotti would withhold these important organizational advantages from the owners of corporations. Furthermore, although they single out business corporations for regulation, pluralism does not seek to rank or distinguish between associations, such as for-profit and not-for-profit firms, when assessing their contribution to individual welfare. Rather, it encourages competition among as many groups as possible, as an important restraint on government. Restricting the range of activities of targeted groups would put the interests rendered "speechless" at a decided political disadvantage, and would thereby weaken the competitive process.

The pluralist critique of corporate political expenditures. From the perspective of a full-fledged pluralist, however, Bellotti is integrally connected to a recurring issue that the nonpluralist critique ignores, the use of delegation in agency relationships. Had the state won in Bel-

corporate speech falls outside first amendment protection because profit maximization, the objective of corporate speech, is compelled by market forces, and hence is not a product of individual creativity and self-expression. By contrast, Charles O'Kelley relates associational rights to the Bellotti issue of corporate speech, combining in his analysis an interest group and individual perspective, to advocate a limited role for corporate political activity when it expresses the interests of the shareholders. O'Kelley, supra note 210. The disagreement between Baker and O'Kelley can be located in Baker's failure to integrate the two elements of his formulation of the problem, the relationship between individuals protected by the first amendment and their association in groups. The union of these themes is the organizational component of pluralism, which is implicit in O'Kelley's associational thesis of corporate rights.

Even scholars who endorse the Bellotti result affirming corporate political speech rights typically do not stress the associational rights of the members of corporations and hold views of the first amendment closer to Baker's than to O'Kelley's. Martin Redish, for example, has developed an individual self-realization theory of the amendment, which he finds supports Bellotit because of the impact of a ban on the rights of the listening voters and not the speakers. Redish, Self-Realization, Democracy, and Freedom of Expression: A Reply to Professor Baker, 130 U. PA. L. REv, 678 (1982). Only a small minority of commentators support the Bellotti decision on a theory of interest group politics. See Bolton, Constitutional Limitations on Restricting Corporate and Union Political Speech, 22 ARIz. L. REV. 373 (1980); Powe, Mass Speech and the Newer First Amendment, 1982 SUP. CT. REv. 243, 254-60. 
lotti it would have been a disastrous result, for it would have severely constrained the ability of individuals to employ agents to communicate ideas. ${ }^{215}$ The important question raised by Bellotti for pluralists is not arcane constitutional distinctions between the rights of hearers and speakers, or of corporations and natural persons, but rather, the more practical distinction concerning whose interests the political expenditures serve, shareholder-principals or manager-agents.

Some Bellotti critics have directed their attack against the agency problem. In contrast to most first amendment specialists, these commentators object to the decision for failing to protect minority shareholders who oppose the political positions supported by management, which is considered the spokesperson for the majority of the shareholders. ${ }^{216}$ Implicitly assuming that corporate campaign expenditures are motivated by partisan politics and not profit maximization, their thesis is that shareholders will be unlikely to agree on politics, and would therefore not unanimously approve specific political expenditures. Accordingly, the conclusion is reached that the majority should not be able to use corporate funds to further its preference. Some draw an additional inference, that prohibiting all corporate political expenditures is the most efficient method of protecting the minority, while others would instead install a system of shareholder authorization votes and refunds for dissenters. ${ }^{217}$

Several commentators have refined this critique by resorting to Berle and Means' separation thesis and maintaining that corporate political expenditures reflect the tastes of managers and not a majority of shareholders. ${ }^{218}$ Analogous objections have been raised against corporate PACs, because the corporation pays its PAC's operating expenses but most solicitations are directed to, and most contributions come from, employee-managers rather than shareholders.

215. For a discussion of the problems of applying different standards to proxy speech, see Powe, supra note 214, at 258-60.

216. E.g., Brudney, Business Corporations and Stockholders' Rights Under the First Amendment, 91 YALE L.J. 235 (1981). The minority shareholder problem was also stressed by Justice White in his dissent. First National Bank of Boston v. Bellotti, 435 U.S. 765, 805-06, 816-18 (1978) (White, J., dissenting).

217. See Brudney, supra note 216 , at $249-52,256-64,272-74$. Although a rebate scheme might be an effective means of protecting the minority, it would, however, create serious problems of preference revelation by magnifying the free rider effect: In such a system, the best of all worlds for the individual shareholder is to have the corporation make a contribution he desires while at the same time he receives a rebate by alleging to oppose the funded candidate. Of course, if everyone follows such a strategy, no contribution will be made.

218. E.g., Miller, On Politics, Democray, and the First Amendment: A Commentary on First National Bank of Boston v. Bellotti, 38 WASH. \& LEE L. REv. 21, 38 (1981); O'Kelly, supra note 210 . 
Hence, as a way of circumscribing the influence of corporate PACs, unions and other opponents advocate restricting the contributor base of those PACs to shareholders, on the ground that corporate PACs should represent owners, the individuals in whose interests the firm is to be run, and not managers. ${ }^{219}$

This clever managerialist critique of Bellotti and corporate PACs, which cites the separation thesis to posit a schism between managers and shareholders yet rejects Berle's optimistic assessment of the social benefits of manager control, has been employed to recommend prohibitions, or, at least, further restrictions, on corporate political speech, and express shareholder approval of political expenditures in advance of disbursement. ${ }^{220}$ However, in a sense, the analysis proves too much. A consistent managerialist could reasonably view corporate political expenditures as providing no cause for special alarm. For if managers can and do appropriate to themselves as large a compensation package as possible, as a managerialist would contend, then the payments to PACs, being a dollar for dollar reduction in some other form of salary, are out-of-pocket expenditures over which shareholders need not be particularly concerned.

In sum, the shareholder-based objection to Bellotti and corporate PACs is a pluralist critique derived from the perennial principalagent problem. Its managerialist approach is quite different from the first amendment challenges. Acknowledging that the corporation speaks for its individual members, this position opposes corporate political activity because of who controls that speech-the managers-and does not resist, in the abstract, individuals using their firms to express their views. Like the Court, these critics therefore espouse a pluralist ideal. The quarrel between supporters of Bellotti and corporate PACs and the shareholder-protection critics is essentially an empirically-resolvable dispute among pluralists. The questions that need to be answered are whether corporate political expenditures harm shareholders, and whether shareholders would genuinely object to the expenditures.

Casual empiricism supports the contention that corporate PACs and political expenditures are in fact vehicles for profit maximization. Corporate PACs seem to be found more frequently in regulated industries, ${ }^{21}$ a fact that suggests that PACs tend to be established

219. E.g., Jessup, supra note 203; Mayton, Politics, Money, Coercion, and the Problem With Corpurate PACs, 29 EMORY L.J. 375 (1980).

220. E.g., Brudney, supra note 216; Miller, supra note 218.

221. Epstein, supra note 197, at 132-38. Because of the regulation, the product markets 
when there is a substantial connection between government policies and the maintenance of firm profits. In addition, the state referenda attracting heavy corporate spending have primarily involved issues closely related to the profitability of the firms making the expenditures. For instance, bottling companies and the container industry spent large sums to defeat a beverage container deposit referendum, and utility companies were the major contributors against an initiative to reform public utility rate regulation. ${ }^{222}$ It is hard to imagine shareholders objecting to such expenditures for diminishing the value of their investment. Finally, the disciplining power of markets aided by appropriate incentive contracts restrains managers from consistently engaging in political activities adverse to shareholder interests. ${ }^{223}$

However, to forge a broad consensus on the impact of political expenditures upon shareholder wealth, additional information would have to be collected. First, we would want to test whether share values of corporations without PACs are higher than those of comparable corporations with PACs-in other words, do firms experience positive (or negative) abnormal returns when they establish PACs? ${ }^{24}$

of these firms may not be perfectly competitive. This fact arguably raises questions concerning what the managers maximize. But the capital and labor markets still act as constraints on these firms. Cf. Jensen \& Meckling, Theory of Firm Managerial Behavior, Ageng' Costs and Ownership Sinucture, 3 J. FIN. ECON. 305, 329-30 (1976) (owners of firms with monopoly power have same incentives to limit managers' divergence from value maximization as owners of competitive firms).

222. Mastro, Costlow \& Sanchez, Taking the Initiative: Corporate Control of the Referendum Process Through Media Spending and What to Do About It, 32 FED. COM. L.J. 315, 321-23 (1980); see Council on Economic Priorities, Study, Bankrolling Ballots Update 1980 (1981). The managerialist explanation of corporate political expenditures may have gained plausibility from the peculiar posture of the issue in Bellotti. Massachusetts had prohibited corporate expenditures only on referenda that did not "materially affect" the corporation's business or property, and the statute further specified that individual income taxation was not material. Although the plaintiff companies maintained that an individual income tax would materially affect their businesses, the courts did not rule on the statute's conclusive presumption and considered instead the permissibility of imposing any restrictions on corporate speech. Commentators have in turn adduced from Bellotti that corporations expend funds on political matters unrelated to their profitability and contrary to the shareholders' interests or unanimous consent. However, apart from the Massachusetts legislature's questionable finding of nonmateriality, as the data on initiative spending indicate, there is meager support for such claims.

223. Of course, the argument in the text just reemphasizes that the heart of the dispute is the longstanding debate between the managerialist and profit-maximizing models of the firm. Only a few commentators make reference to the effectiveness of market constraints on managers making political expenditures. E.g., Prentice, Consolidated Edison and Bellotti: First Amendment Protection of Corporate Political Speech, 16 TuLSA L.J. 599, 633-35 (1981).

224. The testing of share values might not be conclusive because the size of the amounts 
We would further want to know whether corporate PACs support candidates who have congressional responsibilities related to the donor's business or who consistently vote for legislation that is detrimental to the contributing corporation's profitability or that favors the interests of managers over shareholders. ${ }^{225}$ Moreover, it would also be useful to compare the political expenditures of public corporations and closely-held concerns, and the compensation packages of managers of firms that have PACs and those that do not. The answers to these questions would greatly aid in resolving the controversy over whether pluralists need to be concerned about corporate political activity for the sake of shareholders.

Reformulating a pluralist position on corporate political speech. In the absence of such information, endorsing management-directed corporate political activity is not, a priori, contrary to a pluralist view of the firm. Managers are in a better position than shareholders to be informed about the probable effects of legislative policies on the business, and they are more likely to familiarize themselves with the voting records of officeholders on critical matters. For shareholders, who may be geographically distant from the firm's operations, will have less time or inclination to pay attention to the intricacies of political factors, including the dynamics of local politics, that affect their stock. This is particularly true if they are diversified investors, because their welfare is less tied to the firm's fortunes than the managers'. ${ }^{226}$ For similar reasons, managers may be more effective com-

involved may be too small compared to firm values to be statistically significant. In addition, if PACs increase share values, a strong rational expectations view would hypothesize firm value to increase upon the enactment of the legislation authorizing PACs, and not upon a firm's actual establishment of a PAC, for it would ascribe to investors the knowledge that managers would take the necessary steps to maximize value and set up a PAC at the appropriate time in the future.

225. There is some data on the connection between the recipients of PAC funds and a business' affairs: Both corporate and union PACs tend to give to congressmen on the oversight committees of importance to their industries. See Malbin, supra note 202, at 169-77. Moreover, a recent study of the congressional campaign expenditures of twenty-seven corporate PACs in the oil, defense and automobile industries and six union PACs found that, although there were industry differences, contributions correlated significantly with the candidate's voting record on key industry issues, his assignment to industry-relevant committees, his coming from the firm's home district, and, to a somewhat lesser extent, his ideology. Gopoian, What Makes PACs Tick?' An Analysis of the Allocation Palterns of Economic Interest Groups, 28 AM. J. POL. SCI. 259 (1984).

226. Portfolio diversification, however, might justify a prohibition on corporate expenditures: If the successes or failures of political outcomes are firm specific risk, diversified shareholders would not want their agents devoting effort to reducing it because such investors care only about market risk. See R. Brealey \& S. Myers, Principles of Corporate Finance 
municators of the corporation's position than shareholders. Shareholders could therefore quite reasonably prefer that managers organize the firm's political activity. Indeed, because free rider problems would accompany independent shareholder action, the shareholders' interest may demand management direction.

The free rider phenomenon associated with public goods and shareholder collective action may further justify the corporation's defrayal of PAC operating expenses. It would not be in the interests of an individual shareholder to set up a PAC because the individual's cost would typically be far greater than his benefit: He cannot exclude the other stockholders from receiving their pro rata share of the benefits, which accrue to their stock whether or not they individually contribute. This goes some way in explaining the desirability of having the corporation finance the establishment of the PAC, for by such a technique, each shareholder automatically bears his proportional organizational costs. It would also be cheaper to use the existing corporation to finance political activities than to form another shareholders' association for that special purpose. But the analysis still fails to explain why managers or shareholders make individual contributions to PACs, since the same asymmetry between costs and benefits applies to the actual contribution. Mercifully, this is not a puzzle unique to corporate PACs but it is endemic in the campaign financing literature, and to develop an answer would take us too far afield. ${ }^{227}$

123-33 (2d ed. 1984). But, it is unlikely that the risk of adverse election results can be fully diversified, as the political environment towards business regulation would contribute to systematic risk. In addition, favorable election outcomes may increase firm returns directly and not simply reduce risk, in which case, regardless of the diversification argument, shareholders would benefit from the expenditures.

227. The public goods analysis of PAC expenditures in the text is based upon an analogy to the campaign contribution literature, which often employs a public goods model. See, e.g., G. JACOBSON, supra note 201, at 57-64. Undoubtedly, the use of committees confers the benefit of collective action for a unified purpose, for by aggregating their contributions, donors can have a greater impact than by giving individually. However, consumption motives tend to dominate the explanations in the political science literature of the behavior of small contributors. G. Jacobson \& S. Kernell, Strategy and Ghoice in Congressional EleCtIONS 38 (1981); G. JACOBSON, supra note 201, at 68 . We do know two facts about PAC contributors. First, they are less likely to be politically active than those who contribute to parties or candidates directly. H. AlEXANDER, supra note 202, at 94 . Second, most corporate PACs solicit managers and not shareholders. Id. at 92. An interesting explanation for why managers, and not shareholders, are the main source of contributions to corporate PACs, is that managers may have a greater inducement to contribute because their wealth is less diversified than that of shareholders, and thus more dependent upon the firm's fortunes. In addition, because the names of donors of amounts over $\$ 100$ must be disclosed, managers, unlike shareholders, might contribute out of reputational concerns, if contributing is a signal of a 
Although the managerialist critique is therefore not the last word on the issue, it is important because it provides identifiable normative bearings. When the corporation is viewed as expressing the preferences of individuals, be they managers or shareholders, then criticism of corporate political speech can be placed in a pluralist framework. The grammatically permissible pluralist arguments for restricting corporate political speech take two forms, which are related to the two pluralist functions of government. One concerns the information voters receive during campaigns, and the other the distribution of wealth.

The first pluralist critique of corporate political speech identifies a perceived political market failure: Voters lack the information necessary for making intelligent choices when campaign spending is lopsided and favors candidates and policies of a particular constituency, the owners of corporations. In keeping with notions discussed earlier, the pluralist regulatory response to this type of problem would be the prompt, full disclosure of the sources of expenditures and contributions during the election campaign, and not increased restrictions. ${ }^{228}$ Voters would thereby be informed of the supporters of different policies and candidates, which corrects the market failure, while no speaker's rights would be impaired.

The second criticism goes beyond the public goods theory of government to the pluralist concern for income redistribution. It is based upon a claim that corporations, representing wealthy individuals, have been able to buy elections and to shift government policies to their advantage. However, reality contradicts such a view: The

\footnotetext{
good manager who is working hard for the shareholders. But the signal from a contribution would not be the same as the signals in the nondissipative signaling models of firm capital structure, Ross, The Determination of Financial Structure: the Incentive-Signalling Approach, 8 BELL J. ECON. 23 (1977), and dividend policy, Bhattacharya, Nondissipative Signaling Structures and Dividend Policy, 95 Q. J. EcoN. 1 (1980), where there are no dead weight losses from the use of a signal because the signal is a contingent promise, and false signals cannot be sustained in equilibrium. Not only is a donation a noncontingent payment, but also, the risk in the payoff from a campaign expenditure includes many more variables outside the manager's control, such as other contributors and voters, than exist in those other contexts. Thus, success does not depend significantly on the manager's efforts in, or knowledge of, the firm's operations. As a consequence, there is no means to penalize a slothful manager who makes a donation and hence to ensure that only truthful signals are given so that a separating signaling equilibrium can emerge.

228. For examples of disclosure proposals, see Hart \& Shore, Corporate Spending on State and Local Referendums: First National Bank of Boston v. Bellotti, 29 CASE W. RES. L. REv. 808, 823-25 (1979); Mastro, Costlow \& Sanchez, supra note 222, at 353-55. The federal laws and all fifty states have some form of disclosure requirements. H. ALEXANDER, supra note 202, at $33-45,163$.
} 
benefits of the programs of the welfare state generally flow to middle income individuals. ${ }^{229}$ This class-based critique, like the market failure one, is often harnessed to proposals for further limits on contributions or for publicly financed campaigns. ${ }^{230}$ Yet even assuming that the analysis is correct, a simpler solution exists-the direct redistribution of income. ${ }^{231}$ The obvious criticism against such a solution is of a second best sort, that redistribution is not politically feasible, and therefore indirect approaches like publicly financing campaigns and lowering spending ceilings are necessary. But because those alternatives aggravate the incumbency effect, the cure may pose more severe problems than the supposed disease.

For neither pluralist objection to corporate political activity, that it produces an information distortion in the electoral process or an income-based bias in government decisions, then, is the better policy the one uniformly favored by critics: instituting additional spending limitations. Yet quite apart from this mismatching of means and ends, the difficulty for a pluralist opposing corporate participation in political campaigns is, as already noted, how to derive a reasoned distinction for prohibiting the expenditures of business corporations but not those of other organized interests. ${ }^{232}$ There are no easy answers to this question, for restricting the political expression of any group of individuals cannot be readily reconciled with pluralism and its conception of the dynamics of an open political process.

\section{Securities Regulation}

The federal securities laws constitute the most visible regulation of corporations. Although the SEC was established soon after the 1929 stock market crash in an era of crisis and broad-based support for regulating financial markets, it has in recent years become the

229. See Stigler, Director's Law of Public Income Redistribution, 13 J. L. \& ECON. 1 (1970).

230. E.g., Wright, supra note 203.

231. Powe, supra note 214 , at 282.

232. Sanford Levinson has sought to distinguish corporate political spending from that of other groups but his analysis is seriously flawed. He contends that private organizations whose authority is derived from consent should have speech rights, in contrast to corporations, and gives as examples "our ideal . . . labor union or political party." Levinson, Escaping Liberalism: Easier Said Than Done (Book Review), 96 HARV. L. REV. 1466, 1479 (1983). Our ideal of the corporation is no different from that of unions or political parties, being grounded in the shareholders' consent. Moreover, shareholders possess far greater freedom because of competitive markets: They can easily shift their funds to other companies if they disapprove of policies, whereas the rank and file members of unions have no such option, and to a lesser extent, neither do the members of political parties. 
target of sustained criticism..$^{233}$ This section provides an overview of three areas of SEC administration that have been the subject of debate: the mandated disclosure system, restrictions on insider trading, and the regulation of shareholder proxy proposals to promote corporate democracy. Most of the controversy over the agency's activities, such as the disputes concerning the continued usefulness of disclosure and insider trading rules, are battles among pluralists. Only the shareholder proxy proposals of the corporate democracy movement, which have much in common with public and special interest director reforms, invoke the language and imagery of other ideals.

Mandated disclosure. Under the federal securities laws, public corporations must provide investors with substantial information on their operations and governance. In the aftermath of sensational congressional hearings on the 1929 crash bringing to light sharp and fraudulent practices by market professionals, President Roosevelt's New Deal opted for disclosure as its regulatory strategy to avert future disasters, rather than the corporatist policies backed by Adolf Berle and others. ${ }^{234}$ Two pieces of legislation are the core of the regulatory framework. The Securities Act of 1933 requires an issuer of new securities to register the shares and file technical documents containing information on its business and financial condition with the SEC, before the securities can be offered for sale to the public. ${ }^{235}$ In addition, the Securities Exchange Act of 1934 mandates continuous disclosure for firms whose outstanding securities are publicly traded. ${ }^{236}$

Mandated disclosure is a regulatory response tied to the pluralist perspective on the role of the state. The SEC's disclosure requirements are uniformly justified as the appropriate solution to a market failure induced by the public goods characteristics of financial information: A corporation's disclosure statements benefit not only the owners, who defray the costs, but also potential investors and share-

233. E.g., S. Phillips \& J. Zecher, The SEC and the Public Interest (1981).

234. J. Seligman, The Transformation of Wall Street (1982). In his recent history of the agency, Joel Seligman repeats the common view that market professionals' sharp practices caused the crash. There are serious questions concerning this scenario, see $M$. Friedman \& A. Schwartz, A MONETARy History of THE UnIted STATES, 1867-1960 (1963), but the counterthesis is itself disputed, P. TEMIN, Did MONETARY Forces Cause THE GREAT DEPRESSION? (1976).

235. Securities Act of 1933,15 U.S.C. $\$ \S 77 a-77 a a(1976)$.

236. Securities Exchange Act of 1934, 15 U.S.C. $\$ \S 78 \mathrm{a}-78 \mathrm{hh}-1$ (1976). 
holders in other firms. ${ }^{237}$ It is therefore thought that in the absence of regulation, financial information will be undersupplied because firms will not include benefits to third parties in the cost-benefit calculations determining the quantity and quality of information produced.

In addition, securities markets may fail because of information problems that are unrelated to the attributes of public goods. Competitive markets operate efficiently when there is perfect information. If markets are imperfect because the transacting parties have asymmetrical information about the quality of the goods, a lemons problem can occur: When buyers cannot distinguish between poor and high quality items by direct observation, sellers can pass off low quality goods (lemons) for high ones. Anticipating this strategy, buyers will pay no more than the value of a low quality good and, as a result, high quality goods will be driven out of the market. ${ }^{238}$ In this context, disclosure rules could help sustain an otherwise unattainable equilibrium for high quality goods production. The market for new securities issues basically fits this model-investors, who have less information about the quality of an investment than its promoter, cannot distinguish the good firms from the bad before purchase. The disclosure requirements and the penalty of strict liability for their violation imposed by the 1933 Act could serve as a warranty of firm quality, by deterring the offering of low quality investments. This is not to say that only government action could remedy the alleged market failure; private institutions such as financial intermediaries or direct guarantees enforceable by courts undoubtedly can, and do, perform sorting functions as well. The analysis merely provides the backdrop for possibly involving the state, and accordingly, for assessing comparative institutional advantages. ${ }^{239}$

This pluralist rationale of market failure frames the mandated disclosure debate. Much of the dispute turns on the different priors of minimal and welfare state pluralists concerning the need for the federal government's aid of the invisible hand of the marketplace. Advocates of an active role for the SEC contend that investors are able to make superior decisions because mandated disclosure imparts

237. E.g., W. Beaver, Financial Reporting: An Accounting Revolution 189-90 (1981); S. PhILlips \& J. ZEChER, supra note 233, at 18-19.

238. See Akerlof, supra note 12.

239. For experimental evidence on the existence of the lemons problem and on when intervention may produce efficiency gains, see M. Lynch, R. Miller, C. Plott, \& R. Porter, Product Quality, Informational Efficiency, and Regulations in Experimental Markets (1983) (unpublished manuscript). 
valuable information that would otherwise not be divulged. ${ }^{240}$ Critics of the agency claim that private arrangements would produce all of the pertinent, or at least cost-justified, information, and they stress the expense of complying with the agency's regulations. ${ }^{241}$ In accord with the limited need minimal state theorists attach to the state's provision of public goods, critics also question the appropriateness of a public goods analysis for financial information. ${ }^{242}$ This perspective is supported by recent work in economics suggesting that information may, in fact, be privately overproduced. ${ }^{243}$

Critics of the agency further find allies in literature on regulation, which has oscillated between two theses: the conventional market failure explanation, and a newer capture theory that regulation serves the regulated and not the public interest. In brief, the capture theory posits that because firms cannot enforce collusive agreements not to compete, they use the regulatory process to maintain cartels. ${ }^{244}$ This is a relentless application of the self-interest behavioral explanation of the political process. But a troublesome point for the theory has been the support for deregulation of the hypothesized beneficiaries. The targets of the SEC's disclosure policy are primarily corporate issuers, and most corporations oppose the regulation. However, foes of the SEC, applying the insight of the capture theory, perceive the regulatory scheme to benefit security analysts, lawyers, and accountants, and neither investors nor firms. ${ }^{245}$ In this regard, the private institutions that bridge the information gap could be the principal beneficiaries and supporters of the disclosure laws.

To choose between the two theories of regulation that motivate opposing assessments of the SEC's mandated disclosure system would require obtaining data on the extent of market failure or cartelization, and on the comparative costs of government and of private institutional solutions to the information problem. Important ancillary

240. E.g., J. Seligman, supra note 234. See Anderson, The Disclosure Process in Federal Securities Regulation: A Brief Review, 25 HAstings L.J. 311 (1974) (discussing evolution and philosophy of the objectives of the securities laws).

241. E.g., S. PHILlips \& J. ZECHER, supra note 233.

242. Manne, Economic Aspects of Required Disclosure Under Federal Securities Laws, in WALL Street In TRansition 21, 41-43 (The Charles C. Moscowitz Lectures Number XV, 1974).

243. See Hirshleifer, supra note 185, at 573; Fama \& Laffer, Information and Capital Markets, 44 J. Bus. 289, 298 (1971). But see Barzel, Some Fallacies in the Interpretation of Information Costs, 20 J. L. \& ECON. 291 (1977) (private production not inefficient, as Hirshleifer and Fama \& Laffer imply, but cost-minimizing, and therefore, net value-maximizing activity).

244. The classic formulation of the capture theory is by George Stigler in Stigler, The Theory of Economic Regulation, 2 Bell J. ECON. \& MGMT. SCI. 3 (1971).

245. E.g., S. Phillips \& J. Zecher, supta note 233, at 51, 118. 
questions for research would include, what information, if any, was disclosed voluntarily prior to the adoption of the federal laws, did the legislation alter the distribution of the costs of the information problem, and what effect on share prices, as the measure of investor welfare, did the legislation have?

Empirical investigations of the agency's impact have been undertaken over the last two decades to try to answer some of these questions. The SEC's critics have made their case against mandated disclosure by marshaling evidence, starting with well-known early studies by George Stigler and George Benston, showing that the passage of the securities acts did not significantly increase share values, and that most of the required information had been voluntarily disclosed prior to the enactments. ${ }^{246}$ SEC supporters, however, have questioned the methodology of those studies and have generated conflicting data concerning the effect of the federal laws. ${ }^{247}$ While the findings to date are still the subject of disagreement, the issue of mandated disclosure exemplifies pluralist disputes, which hold out the prospect of building a consensus through additional research.

Insider trading. The controversy over the SEC's regulation of insider trading conjures up a sense of deja $v u$ in light of the mandated disclosure debate. An offshoot of the agency's disclosure objective, the insider trading rule requires corporate insiders with material information who wish to trade in their firm's securities either to disclose the information or to refrain from trading. ${ }^{248}$ Like mandated disclosure, insider trading regulation raises core pluralist concerns. Positional advantages in securities trading from asymmetrical information can exacerbate the agency problem of the divergence of interest between shareholders and managers, and arguably contributes to a form of market failure.

A common theme characterizes the position of all advocates of some trading restraint: Unrestricted insider trading is believed to reduce shareholder welfare. Government intervention is considered

246. E.g., Benston, Required Disclosure and the Stock Market: An Evaluation of the Securities Exchange Act of 1934, 63 AM. EcoN. REv. 132, 144-49 (1973); Jarrell, The Economic Effects of Federal Regulation of the Markel for New Security Issues, 24 J. L. \& ECON. 613 (1981) (reworking Stigler study with more sophisticated statistical techniques); Stigler, Public Regulation of the Securities Markets, 37 J. Bus. 117, 121 (1964).

247. E.g., Friend \& Herman, Through a Glass Darkly, 37 J. Bus. 382 (1964) (critique of Stigler study); Friend \& Westerfield, Required Disclosure and the Stock Market, 65 Am. Econ. REV. 467 (1975) (critique of Benston study).

248. SEC v. Texas Gulf Sulphur Co., 401 F.2d 833 (1968), cert. denied, 394 U.S. 976 (1969). 
necessary because the free rider problem of shareholder coordination would render private enforcement of a prohibition difficult. From this perspective, the insider trading ban lowers agency costs by replacing direct shareholder monitoring of managers with the statute's deterrent force. Further, it may eliminate potential market inefficiencies. Because an insider's trades provide implicit information about his firm's prospects, a requirement of disclosure could enhance market efficiency by increasing the amount of information insiders must communicate while lowering the costs to outsiders of determining whether insiders are trading. ${ }^{249}$

Insider trading is most explicitly treated as an agency issue by Alison Anderson, who contends that the duty to disclose or abstain should be imposed only on individuals, such as corporate insiders or market professionals, who are hired by investors to act on their behalf. ${ }^{250}$ By premising liability on express agency relationships, the insider trading prohibition becomes an explicit device to reduce the costs of contracting: The statute supplies a standardized term-a penalty clause to enforce agent loyalty-which investors no longer need to negotiate separately with managers. A variant of this position, derived from specification of property rights in information, has been suggested by both Frank Easterbrook and Kenneth Scott. ${ }^{251}$ In this scenario, inside information belongs to the firm, and hence to shareholder-principals rather than the agents in their employ. The property rights view is, in essence, an elaboration of an agency theory of insider trading that sees two functions for regulation: providing optimal incentives for the production of new information, as well as aligning shareholder and manager interests. ${ }^{252}$ The goal is no different from that of Anderson's more limited definition. Easterbrook and Scott maintain that a policy protecting discovery values in information maximizes shareholder wealth by strengthening the efficiency of the market for corporate control. ${ }^{253}$

249. Ross, Diselosure Regulation in Financial Markets: Implications of Modern Finance Theory, in Key Issues in Financial. Regulation 177, 182 (F. Edwards ed. 1978).

250. Anderson, Fraud, Fiduciaries and Insider Trading, 10 HofSTRA L. Rev. 341, 375-76 (1982).

251. Easterbrook, Insider Trading, Secret Agents, Evidentiary Privileges, and the Production of Information, 1981 Sup. CT. Rev. 309; Scott, Insider Trading: Rule 10b-5, Disclosure and Corporale Privacy, 9 J. Legal STud. 801 (1980).

252. Easterbrook, supra note 251, at 331-32; Scott, supra note 251 , at 808,815 .

253. The difference between the theory of liability espoused by Anderson and by Easterbrook and Scott surfaces primarily in their positions on a leading Supreme Court decision, Chiarella v. United States, 445 U.S. 222 (1980), which held a financial printer was not liable for trading on inside information he obtained from his work concerning an upcoming take- 
By contrast, Saul Levmore advocates greater restrictions on insider trading, requiring disclosure and rejecting the option of nontrading silence. ${ }^{254}$ Levmore deems mandatory disclosure the fairest rule because by equalizing the positions of insiders and outsiders it eliminates envy to be in each other's place. ${ }^{255}$ It is a rule that seeks to mitigate agency problems by ensuring that information developed or obtained during the employment relationship can never be used to the agent's advantage against a shareholder-principal on the stock market. Levmore further contends that the "always disclose" rule is the most effective rule for reducing market inefficiencies created by asymmetrical information. This conclusion turns on his analysis of the relevant markets for evaluating insider trading, an analysis that stresses the effects of nondisclosed corporate information upon a variety of local markets in addition to the capital market. The endorsement of more extensive restrictions on insiders depends critically upon an expansive definition of the agency relationships and markets pertinent to policy analysis, the costs and benefits of which are presumably measurable.

The leading critics of insider trading restraints share its proponents' pluralist view, that the object of the regulation of corporations is the protection of shareholders. ${ }^{256}$ But they disagree sharply over

over. While Anderson's approach searches for precisely articulated agency relationships and thus adheres to the Court's restricted scope of insider liability, Easterbrook and Scott would hold Chiarella liable. A property rights approach enables them to extend the trading prohibition to include the agency relationship existing between Chiarella's employer and its customer, the tenderor, rather than to consider only explicit agency relations with investors, and is intended to maintain the incentives of tenderors for producing information on targets.

254. Levmore, Securities and Secrets: Insider Trading and the Law of Contracts, 68 VA. L. REv. 117 (1982).

255. Id. at 123. Levmore's standard is similar to that of economists who have formalized an envy free principle of fairness for approaching questions of distributive justice. E.g., Varian, Equity, Envy and Efficiency, 9 J. ECON. THEORY 63 (1974). While Levmore bases his arguments on fairness and efficiency considerations, strictly envy free allocations may not be Pareto optimal (efficient). Id. at 68-73; Feldman \& Kirman, Faimess and Envy, 64 AM. ECON. REV. 995, 998-99 (1974). Levmore maintains, however, that the insider trading rule that most closely follows the envy free criterion creates few inefficiencies, Levmore, supra note 254, at 127,152 . Victor Brudney has advocated an equal access theory of insider trading that expresses analogous concerns to Levmore's, although he supports the disclose or abstain rule and not an "always disclose" approach. Brudney, Insiders, Outsiders, and Informational Adiantages Under the Federal Securities Laws, 93 HaRV. L. REV. 322 (1979).

256. For instance, as Alison Anderson noted, despite their opposing positions on insider trading, both Victor Brudney and Michael Dooley characterize the regulatory rationale as directed toward unfaithful agents. Anderson, supra note 250, at 373. Organization theory explanations have also been used to support insider trading regulation on the ground that the prohibition enhances firm efficiency by eliminating intra-managerial tensions and agent subgoal pursuits. See Haft, The Effect of Insider Trading Rules on the Intermal Efficiency of the Large 
the empirical effect of insider trading regulation on shareholder wealth. They also tend to emphasize questions of capital market efficiency over delegation problems, a priority reminiscent of the approach of pluralists challenging the usefulness of independent director reform.

For instance, in a study of the enforcement of insider trading rules, Michael Dooley considers a finding of negligible evidence that insider trading harms shareholders crucial to his position against regulation. ${ }^{257}$ Similarly, Dennis Carlton and Daniel Fischel state that the absence of private contracts prohibiting insider trading, both before and after the advent of the federal ban, demonstrates that shareholders view insiders' gains from trading to be an acceptable form of executive compensation. ${ }^{258}$ While this is a prototypical pluralist argument, to favor the decisions expressed in private contracts over contrary legislated choices, in application it is pluralism with a bizarre twist. For by setting the property rights to corporate information in managers and not shareholders, the roles of shareholders and managers are stood on their heads: The managers become the residual claimants while the shareholders are relegated to a fixed return. ${ }^{259}$

This approach to insider trading as a matter of the employment contract is an extension of the thesis of Henry Manne, who was the first to question the insider trading prohibition. He maintained that insider trading profits are a form of compensation necessary to en-

Corporation, 80 MicH. L. REv. 1051 (1982). The efficiency gains Haft seeks should increase the value of the firm, which will improve shareholder welfare, but he does not explicitly articulate such an objective.

257. Dooley, Enforcement of Insider Trading Restrictions, 66 VA. L. REv. 1, 31 \& ff (1980).

258. Carlton \& Fischel, The Regulation of Insider Trading, 35 STAN. L. REV. 857 (1983). The significance attributable to silence a priori is ambiguous. The absence of contracts permitling insider trading could as easily be stressed because compensation terms are typically specified with substantial detail in employment contracts.

259. To take a familiar example, when Eli Whitney invented the cotton gin, he could exploit his clever idea either by manufacturing the gin or by trading in cotton futures. The question posed by insider trading is should managers have the second opportunity. If the corporation makes the gin, the present value of the discovery is realized generally by all the shareholders. If instead, the managers trade on the information first, then they gobble up some of the discovery value that would otherwise have accrued to the selling shareholders. The role reversal is apparent if we view the shareholders' sale as a corporate liquidation: The effect is to give the managers an unstated residual claim to the firm's assets while the selling/ liquidating shareholders become senior claimants entitled solely to regular returns but not discovery values. Furthermore, to state the obvious, if the managers speculate in cotton stock and do not have the firm manufacture the gin, no stockholders will share in the discovery value. 
courage entrepreneurial risktaking. ${ }^{260}$ Manne also contended, as Carlton and Fischel have elaborated, that market efficiency is actually improved by insider trading because the trades carry information and thereby push share prices in the right direction. Based on these two claims, that insider trading is a form of incentive compensation and a means to further the efficient pricing of stocks, these commentators conclude that shareholders suffer no harm from such activity. By portraying the issue as the manager's contract compensation right, they are able to bypass the agency problem presented by insider trading.

The striking feature of the insider trading debate is that the disagreement clearly stems from different factual assumptions concerning the impact of insider trading on investors. If it could be demonstrated that shareholder wealth is maximized by the regulation of insider trading, then the opposition to insider trading restraints would disappear. It is problematic whether the hypothesis could ever satisfactorily be tested, and to compound the difficulty, whether a prohibition on insider trading could be adequately enforced. In addition to Dooley's research on litigation, there have been empirical studies on insider trading showing that insiders earn positive abnormal returns on their trades, and that the adoption of the disclose or abstain rule did not significantly reduce the profitability of insider trading. ${ }^{261}$ Without question, the highly technical issue at the bottom of the debate makes plain that the antagonists agree on fundamentals. This theme, common to both mandated disclosure and insider trading, is markedly absent from the discussion of the SEC's regulation of shareholder proxy proposals.

Shareholder proxy proposals for corporate democracy. Although the corporate democracy movement shares many of the objectives of the public interest and constituent-based director reforms discussed earlier, it focuses on an alternative mechanism for change, shareholder initiative. The movement emerged in the early 1970's as a tactic of self-styled corporate activists who discovered the wondrous benefits of SEC rule $14 a-8$, which details when management must include

260. H. Manne, Insider Trading and The Stock Market (1966).

261. E.g., Finnerty, Insiders and Market Efficiency, 31 J. Fin. 1141 (1976) (examining returns to insider trading); Jaffee, Special Information and Insider Trading, 47 J. Bus. 410 (1974) (examining effect of changes in regulation on insider trading). These studies do not answer the additional interesting question, whether there is any damaging effect on the trading managers or firms after a violation has been discovered. 
shareholder proposals in the firm's proxy materials. ${ }^{262}$ The source of the fascination with this otherwise obscure rule was straightforward: If a proposal could be placed in a corporation's proxy, it could provide a lever to generate public exposure of pressing social issues without much cost to the proponent because the corporation bears the expense of the proxy process. ${ }^{263}$ By acquiring a nominal number of shares, critics of business policies could therefore gain access to a new audience, investors, while attracting press coverage that would enable them to drum up more public attention and support for their cause. For the tactic to work, corporate executives would have to play along as the villains in the drama, appearing to be the intransigent enemies of democracy by opposing a mini-electoral process within the firm. But once managers caught onto the game and quietly placed the initiatives on the agenda along with lengthy opposition statements, the media lost interest because the dramatic catharsis fizzled, and the activist movement shifted its energy to inducing legislative, rather than shareholder-proposed, reform.

The crucial issue in the administration of Rule $14 \mathrm{a}-8$ that creates the potential for drama is whether management can omit a shareholder's proposal under one of the rule's specified exclusions. The omissible topics include proposals that are "not significantly related to the [issuer's] business" or that "relat[e] to . . . ordinary business operations."264 But if management decides to exclude a proposal, that determination must undergo SEC review. ${ }^{265}$ The rationale for the rule, and its use by the first advocates of shareholder proposals, was to enable shareholders to assert control over wayward manag$\mathrm{ers},{ }^{266}$ but the most prominent enthusiasts of the technique have had other goals than increasing shareholder wealth. The corporate democracy movement advanced shareholder proposals that sought to

262. 17 C.F.R. $\$ 240.14 a-8$ (1983). The only filings under the continuous disclosure rules that shareholders receive directly are the firm's proxy materials, which must accompany management's solicitation of proxy votes.

263. See Schwartz, The Public-Interest Proxy Contest: Reflections on Campaign GM, 69 Мich. L. Rev. 419 (1971).

264. Rule 14a-8(c)(2) \& (5), 17 C.F.R. $\$ \$ 240.14 a-8(c)(2) \&(5)$ (1983).

265. Rule 14a-8(d), 17 C.F.R. § $240.14 a-8$ (d) (1983).

266. Shareholder proposals and rule $14 \mathrm{a}-8$ have been used ever since the 1930 's to promote managerial accountability to shareholders, with the more popular resolutions calling for the adoption of cumulative voting, preemptive rights, and restrictions on management compensation. Black \& Sparks, The SEC as Referee-Shareholder Proposals and Rule 14a- 8 , 2 J. CORP. L. 1, 3-4 (1976). In the earliest challenge to the exclusion of a shareholder proposal that was of this sort, the SEC supported the shareholders against management. SEC v. Transamerica Corp., 163 F.2d 511 (3d Cir. 1947) (proposal to amend bylaws to allow shareholders to select auditors). 
infuse corporate policy with goals distinct from profit maximization and to effect a restructuring of the board of directors along with a reordering of decisional priorities. ${ }^{267}$ Although the gist of such proposals might seem to fall within the excludable class of issues unrelated to the firm's business, the SEC's interpretation of the category shifted over time from initially construing very narrowly the appropriate subjects of shareholder initiative, to eventually tolerating broad policy-oriented proposals. For example, in one of the first proxy proposal challenges, the SEC supported the Dow Chemical Company's omission of a proposal to end its production of napalm, which was used in the Vietnam War, ${ }^{268}$ but subsequently, it required Motorola to include a proposal demanding the cessation of commercial contacts with South Africa, and denied public utility companies the right to exclude proposals opposing the construction of nuclear power plants. ${ }^{269}$

Despite victories within the agency, the corporate democracy movement received virtually no support from shareholders. ${ }^{270}$ Then again, that was not the audience the proposal proponents were actually targeting. Shareholders are concerned with profit maximizing, and the proposal proponents did not profess to be interested in firm efficiency or optimizing economic behavior. They typically adopted a Berlian view of the corporation as a private government or political institution, which conceptually permits the introduction of social issues into internal firm affairs, and they attempted, correspondingly,

267. For example, Campaign GM's resolutions included the creation of a Shareholders Committee for Corporate Responsibility, consisting of representatives of various interests who would be selected by GM's board and union and the lawyers running the campaign. The committee was to gather facts and make recommendations on "basic questions concerning the corporation, such as its role in modern society and its prospects for and possible means of achieving a proper balance between the interests of shareholders, employees, consumers, and the general public," to consider how to broaden the corporation's decisional base by changing the selection process for directors, and to evaluate GM's past use of "its economic power to contribute to the social welfare of the Nation." Schwartz, supra note 263, at 424-25.

268. Medical Comm. for Human Rights v. SEC, 432 F.2d 659 (1970), vacaled, 404 U.S. 403 (1972).

269. See, e.g., Exchange Act Release No. 12,999, [1976-1977 Transfer Binder] FED. SEC. L. REP. (CCH) I 80,812, at 87,131 (public utility company's construction of nuclear power plant is not an ordinary business matter); Motorola, Inc., SEC Div. of Corp. Fin. Staff Reply (Feb. 23, 1978), reprinted in L. Solomon, R. Stevenson \& D. Schwartz, Corporations LaW and Policy Materials and Problems 528-30 (1982) (permitting inclusion of proposal challenging business with South Africa).

270. Most proposals failed to obtain the minimal percentage of votes required under the rule to qualify for resubmission in succeeding years. Rule 14a-8(c)(12), 17 C.F.R. $\S 240.14 a-8(c)(12)(1983)$. 
to imbue corporate decisions with a public interest. ${ }^{271}$ Thus, they proposed that management consider interests besides those of shareholders in policy-making and in selecting directors. Donald Schwartz, a leader of the corporate democracy movement, made explicit this organic conception of the corporation when he criticized constituency boards because the directors so elected would not be "one overall group concerned with balance." 272 In addition, the Berlian view of the important constraining influence of public opinion on managers entered prominently into the corporate democracy movement's strategy. Admitting that their tactics were not aimed primarily at the voting shareholders, corporate democracy supporters anticipated that any significant pressure on corporations to change their policies would come from the nonstockholding public, which would be educated about the issues by media events such as proxy proposal battles. ${ }^{273}$ This politicization of the proxy process, using the annual shareholder meeting as a means of injecting broad-ranging societal concerns into corporate decisionmaking, mirrors the organic conception of politics that rejects the pluralist distinction between public and private.

Unlike the debates over mandated disclosure and insider trading regulation, the spirit of the corporate democracy proxy proposals is therefore not pluralist. Still, some features compatible with individualist ideals can be discerned in the proposals. The corporate democracy movement frequently rallied around proxy proposals calling for the termination of production externalities, such as pollution, ${ }^{274}$ which pluralists also wish to regulate. In addition, at one point Schwartz suggested that antitrust enforcement would be more germane to the aims of the corporate democracy movement than the political restructuring of corporations, because it would achieve the one goal upon which everyone in the movement agreed, reducing the concentration of power. ${ }^{275}$ Such an objective could be supported by individualists of all stripes, for it is consistent with both the pluralist

271. D. VOGEL, LOBByiNG THE CORPORATION 6, 9-10 (1976); Schwartz, supra note 263, at 422, 477; see Curzan \& Pelesh, Revitalizing Corporate Democracy: Control of Investment Managers' Votung on Social Responsibility Proxy Issues, 93 HaRv. L. Rev. 670 (1980). (1971).

272. Schwartz, Towards New Corporate Goals: Co-Existence With Society, 60 GEo. L.J. 57, 87

273. See, e.g., id. at 83; Schwartz, supra note 263, at 481, 485. Proponents candidly admitted that their overriding goal was to alter national policies, and that they believed it was cheaper or easier to gain the attention of a corporation than of Congress.

274. See Schwartz, supra note 272 , at 82 .

275. Id. at $84-85$. 
concern to maintain competition and the atomic individualist proclivity to disassemble corporations.

The mix of corporatist overtones and latent pluralist themes in the corporate democracy movement is similar to the normative tangle of many of the proposals for board reform. But at heart, despite their common content, shareholder proxy proposals are completely different from internal restructuring programs. For their approach does not seek to legislate how corporate affairs are to be arranged, but instead strives for voluntary change through the efforts of individual owners to influence firm decisions. In principle, shareholder access to the proxy mechanism under the SEC rules is crucial to pluralist institutions because by spreading communication costs it alleviates the free rider problem plaguing owners of large publicly-held corporations and thereby provides additional checks on managers.

Yet of all the reforms reviewed in this article, the corporate democracy shareholder proposals pose the most perplexing issue for pluralism. As has been suggested, many advocates of shareholder proposals want to install, by means of their resolutions, a vision of the firm and of society that is incompatible with the pluralist ideal. The dilemma for pluralism is can, or should, the state constrain in any way individual choices, which if implemented on a large scale could undermine the very pluralist order? ${ }^{276}$ In part, such a question is most acute for pluralism because by not demanding particular organizational forms, it emphasizes process over substantive issues and requires a limited government. In the absence of externalities, it restricts the government's role to enabling individuals to order their affairs as they wish, and forbids the state from choosing among the various private arrangements. In addition, it places great weight on maintaining the vitality of a competitive process among groups as the best restraint on government coercion and the means to maximize individual welfare. Hence, to ensure individual liberty, the pluralist state tolerates activities by groups with opposing values. Nevertheless, if it utterly fails to restrict the activities of individuals or groups hostile to its ideal, they may succeed in destroying it.

One line that scholars have drawn to solve this dilemma prohibits private decisions that cut off the possibility of changing a choice in the future. ${ }^{277}$ In the context of shareholder proxy proposals, such a line would exclude few resolutions, as they can be repealed by subse-

276. It is somewhat analogous to the libertarian paradox that individuals may consent to be coerced by the state.

277. See S. Gordon, Welfare, JUSTICE, AND FreEdom 132-33 (1980). 
quent votes and firm activities are usually not irreversible. The SEC's narrowing of the permissible topics for exclusion is in keeping with such a distinction. The line does not, however, resolve a related knotty theoretical question in the proxy proposals controversy, whether a simple majority rule procedure can be used to alter fundamental goals. ${ }^{278}$ Nor does it answer the more practical objection that substantial costs are being imposed on all of the shareholders to subsidize proposals of a minority that has clearly conflicting objectives. Thus, in the end, we can only scratch the surface of the problematic nature of shareholder proxy proposals, for they embody a core tension within pluralism.

\section{IV.}

A central theme of this article has been that political ideals influence conceptions of the corporation and, consequently, the best means for rendering intelligible much of corporate law scholarship is to disentangle disagreement over means from disagreement over ends. It is unfortunate, however, that the quarrel over ideals can only be teased from the more pragmatic concerns of the literature, for when the objectives of a body of scholarship are enigmatic it is easy to misunderstand individual positions. If, along the way, I have mistaken or slighted a point of view, it is not for want of trying to be fair-minded, and I hope that any errors will serve to spark clarification, correction, and discussion. In any event, the test of the usefulness of a mapping of a literature is prospective, the program for research it implies.

The different ideals of democratic organization that the article identifies demand sharply distinctive roles for the corporation and therefore implicate policies that are fundamentally incompatible. For pluralism, the corporation is, as Oliver Williamson put it, "preeminently an engine of efficiency."279 It is a means to achieve individual ends, increasing the welfare of its owners, by its ability to reduce the costs of market transactions and to allocate resources and risk efficiently. In the pluralist conception, corporations are to be run in the shareholders' interest, which is profit maximization, subject to legal constraints that force the internalization of social costs generated by production externalities. This is because by maximizing shareholder wealth the corporation attains productive efficiency

278. See Chirelstein, Corporale Law Reform, in Social ResponsibILITY AND THE BusiNess PrediCAMENT 41, 59-62, 73-74 (J. McKie ed. 1974).

279. ALI Proceedings, supra note 107, at 427. 
while preserving individual freedom of choice. Pluralism further values experimentation, flexibility, and diversity in institutional arrangements, as the means by which efficiency gains can constantly be improved upon. In this regard, Berle and Means' observation of the separation of ownership and control highlights both the efficiency of conducting business affairs in corporate form and the cause of an endemic concern for a pluralist society that builds upon principalagent relationships. Namely, their observation illuminates what has been and will always be the core corporate law issue for pluralists: delineating mechanisms of incentive alignment to control the actions of unfaithful agents.

In the corporatist ideal, the corporation is assigned the crucial role of maintaining social stability. It is expected to eliminate conflict and divisiveness in society by providing a niche in a well-ordered whole that transcends the individual and absorbs him in a collective purpose. As a result, the corporation is not a means to fulfill individual objectives but virtually an end in itself. Profit maximization is but one of a variety of goals that may be pursued in order to achieve social harmony. Issues of agency are not central because the aspirations of the organization are prior to individual preferences, which are also assumed not to conflict with the group's. Hence, the corporatist position fuses the economic role of the corporation with the social functions of government, and endorses policies typified by Berle's reaction to the separation of ownership and control, that the decisions of corporate managers, as guardians of society's welfare, can and should be uncoupled from shareholder desires.

Whereas corporatists aim to eliminate politics through the ordered arrangement of society into corporations, participationists seek to transform the corporation into a political arena. The model of the firm in this ideal is a small, egalitarian, and cohesive group in which all members actively participate in decisionmaking. Efficiency is not a primary objective because it is achieved through the delegation of authority, a device contrary to the participationist premise of the good society. Instead, corporations serve as the building blocks of a participatory democracy. The decisionmaking structure for production is more important than the level of the firm's output and the maximization of shareholder wealth. A corollary of the practice of direct democracy in the corporation is that agency problems are not perceived to be serious issues.

Lastly, the position of the corporation in atomic individualism cannot be readily sketched. Corporate organizations do not appear 
in the utopias of anarchists and radical libertarians, for the focal point is a leviathan state. The organic component of participationism, while flattening and scaling down corporate entities, retains a notion of organization that has no analogue in the individualist decentralized ideal. But some guide to how atomic individualists view the corporation may be gleaned from the populist antagonism to industrial size and concentration: It is an evil, surpassed only by government, that can best be checked by dismemberment.

It becomes evident when the connection between conceptions of the corporation and political ideals is related to corporate law reform proposals that there are two markedly disparate sources of policy disagreement, each of which implies a distinctive agenda for research. Although a significant proportion of debate over reform programs is derived from adherence to opposing ideals, a substantial part of the controversy consists of disputes among pluralists relying on differing descriptions of reality. In these instances of shared values, careful empirical research testing well-specified behavioral theories could provide a basis for creating a consensus on policy prescriptions. In theory, then, the pluralist policy disagreements over regulating business associations could be resolved, for they involve assessing the effectiveness of alternative means. But in practice, there undoubtedly will be disputes over the specification of the model, measurement, and the significance of results. Moreover, the strength of a person's prior beliefs will affect the weight or meaning he attaches to empirical findings. Consequently, the rate or extent of updating upon the publication of new studies may be slow, and agreement may prove to be elusive. However, it is important to remember that when we are in agreement on ends, we should focus on means, and behavioral theories and empirical research can sharpen discussion and aid in forging a political consensus.

Although there has been scant empirical work grounded in a behavioral theory by legal academics, the future for the field is bright. The renaissance in corporate law scholarship today is largely related to the development of financial economics as a research tool. Legal scholars have been able to integrate and apply the theories and empirical results of a flourishing economic literature to obtain a clearer handle on previously muddled issues in corporate law. However, the gains to academic lawyers from engaging in work that is simply derivative of the scholarship of economists are limited. Not knowing the institutional detail, how the law and business world intersect, all but a few economists have been and will continue to be uninterested 
in or unable to identify the important questions for legal research or to offer coherent policy prescriptions. As a result, academic lawyers will have to do much of the research themselves. While this requires legal scholars to acquire additional, and more sophisticated, training in economics and statistics, they have a comparative advantage in the substantive line of research, for they know where the institutional glitches are and how the law works. Indeed, if they do not pursue such studies, no one else will, and the quality of our decisions on corporate law reform will suffer.

Behavioral theories and empirical testing are of little relevance, however, to resolving the other strand of disagreement. In disputes over cherished ideals, the prospects for obtaining agreement are dim because basic judgments can be only loudly asserted and never proven. But by clarifying the differences in the visions of corporate law reformers and joining the debate, we at least begin to determine where the dispute involves value choices and where it founders on the acquisition of more information. 